\title{
Strategies for the Total Synthesis of Diverse Bromo-Chamigrenes
}

\author{
Minxing Shen, ${ }^{1,2}$ Manuel Kretschmer, ${ }^{3}$ Zachary G. Brill, ${ }^{3}$ and Scott A. Snyder ${ }^{1,2,3 *}$ \\ ${ }^{1}$ Dept. of Chemistry, University of Chicago, 5735 South Ellis Avenue, Chicago, IL 60637 \\ ${ }^{2}$ Dept. of Chemistry, The Scripps Research Institute, 130 Scripps Way, Jupiter, FL 33458 \\ ${ }^{3}$ Dept. of Chemistry, Columbia University, 3000 Broadway, New York, NY 10027
}

\section{Supporting Information}

General Procedures. All reactions were carried out under an argon atmosphere with dry solvents under anhydrous conditions, unless otherwise noted. Dry tetrahydrofuran (THF), toluene, dimethylformamide (DMF), diethyl ether $\left(\mathrm{Et}_{2} \mathrm{O}\right)$ and dichloromethane $\left(\mathrm{CH}_{2} \mathrm{Cl}_{2}\right)$ were obtained by passing commercially available pre-dried, oxygen-free formulations through activated alumina columns. Yields refer to chromatographically and spectroscopically $\left({ }^{1} \mathrm{H}\right.$ and ${ }^{13} \mathrm{C}$ NMR) homogeneous materials, unless otherwise stated. Reagents were purchased at the highest commercial quality and used without further purification, unless otherwise stated. Reactions were magnetically stirred and monitored by thin-layer chromatography (TLC) carried out on $0.25 \mathrm{~mm}$ E. Merck silica gel plates (60F-254) using UV light as visualizing agent, and an ethanolic solution of phosphomolybdic acid and cerium sulfate, and heat as developing agents. SiliCycle silica gel (60, academic grade, particle size $0.040-0.063 \mathrm{~mm}$ ) was used for flash column chromatography. Preparative thin-layer chromatography separations were carried out on $0.50 \mathrm{~mm}$ E. Merck silica gel plates (60F-254). NMR spectra were recorded on Bruker 400, 500 and $700 \mathrm{MHz}$ instruments and calibrated using residual undeuterated solvent as an internal reference. The following abbreviations were used to explain the multiplicities: $\mathrm{s}=$ singlet, $\mathrm{d}=$ doublet, $\mathrm{t}=$ triplet, $\mathrm{q}=$ quartet, $\mathrm{br}=$ broad, app = apparent. IR spectra were recorded on a Perkin-Elmer 1000 series FT-IR spectrometer. High-resolution mass spectra (HRMS) were recorded on Agilent 6244 Tof-MS using ESI (Electrospray Ionization), APCI (atmospheric pressure chemical ionization), or Mixed (the Agilent Multimode Source with simultaneous electrospray ionization and atmospheric pressure chemical ionization) at the University of Chicago Mass Spectroscopy Core Facility.

Abbreviations. EtOAc = ethyl acetate, DIBAL-H = diisobuylaluminum hydride, Rochelle's salt $=$ sodium potassium tartrate, $\mathrm{BDSB}=$ bromodiethylsulfonium bromopentachloroantimonate, $\mathrm{CsOAc}=$ cesium acetate, $\mathrm{KHMDS}=$ potassium bis(trimethylsilyl)amide, $\quad \mathrm{Pd}(\mathrm{dppf}) \mathrm{Cl}_{2}=\quad$ [1,1'-bis(diphenylphosphino)ferrocene $]$ dichloropalladium(II), $t$ - $\mathrm{BuOK}=$ potassium tert-butoxide, $t$ - $\mathrm{BuOOH}=$ tert-butylhydroperoxide, $t$ - $\mathrm{BuOH}=$ tert-butanol, $\mathrm{NMO} \bullet \mathrm{H}_{2} \mathrm{O}=4$-methylmorpholine $N$-oxide monohydrate, $\mathrm{SO}_{3} \bullet$ pyr $=$ sulfur trioxide pyridine complex, $\mathrm{DMSO}=$ dimethyl sulfoxide. 


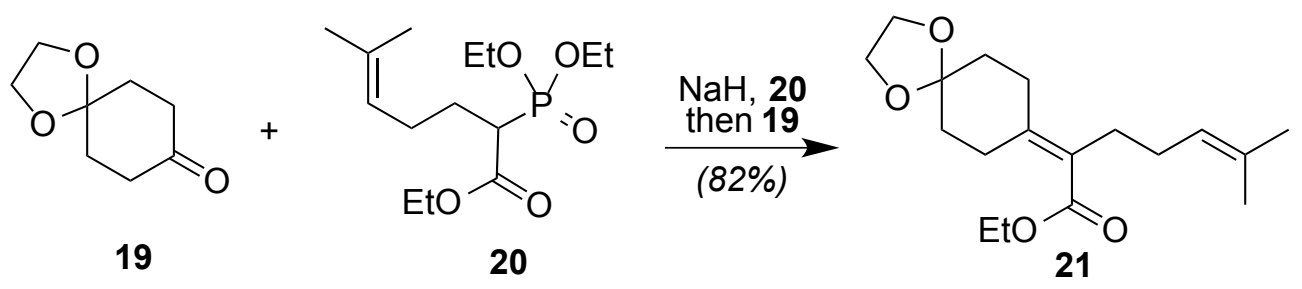

Conjugated Ester 21. To a solution of ethyl 2-(diethylphosphono)-6-methyl5-heptaenoate (20, $3.98 \mathrm{~g}, 13.0 \mathrm{mmol}, 1.2$ equiv) $)^{1}$ in THF $(6 \mathrm{~mL})$ at $23{ }^{\circ} \mathrm{C}$ was added $\mathrm{NaH}$ (60\% dispersion in mineral oil, $0.497 \mathrm{~g}, 12.4 \mathrm{mmol}, 1.15$ equiv) portionwise over the course of $20 \mathrm{~min}$. The resultant mixture was then stirred at $23{ }^{\circ} \mathrm{C}$ for $1 \mathrm{~h}$, at which time solid 1,4-cyclohexanedione monoethylene acetal $(\mathbf{1 9}, 1.69 \mathrm{~g}, 10.8 \mathrm{mmol}, 1.0$ equiv) was added portionwise over the course of $5 \mathrm{~min}$. The reaction contents were then allowed to stir at 23 ${ }^{\circ} \mathrm{C}$ for $10 \mathrm{~h}$. Upon completion, the reaction was quenched by the addition of a half-saturated solution of aqueous $\mathrm{NH}_{4} \mathrm{Cl}(50 \mathrm{~mL})$, the contents were poured into a separatory funnel, and the layers were separated. The aqueous layer was then extracted with EtOAc $(3 \times 20 \mathrm{~mL})$ and the combined organic layers were washed with brine $(30 \mathrm{~mL})$, dried $\left(\mathrm{MgSO}_{4}\right)$, filtered, and concentrated. The resultant residue was purified by flash column chromatography (silica gel, hexanes/EtOAc, 25/1 $\rightarrow 15 / 1)$ to afford 21 ( $2.73 \mathrm{~g}, 82 \%$ yield) as a white solid. 21: $\mathrm{R}_{f}=0.51$ (silica gel, hexanes/EtOAc, 7/3); IR (film) $v_{\max } 2953,2881,1712,1282,1202$, $1161,1123,1081,1035,945,916 \mathrm{~cm}^{-1} ;{ }^{1} \mathrm{H}$ NMR $\left(500 \mathrm{MHz}, \mathrm{CDCl}_{3}\right) \delta 5.11(\mathrm{t}, J=7.2 \mathrm{~Hz}, 1$ H), 4.19 (q, $J=7.1 \mathrm{~Hz}, 2 \mathrm{H}), 3.97(\mathrm{~s}, 4 \mathrm{H}), 2.54(\mathrm{t}, J=6.4 \mathrm{~Hz}, 2 \mathrm{H}), 2.38$ (t, $J=6.5 \mathrm{~Hz}, 2 \mathrm{H})$, 2.32 (t, $J=7.8 \mathrm{~Hz}, 2 \mathrm{H}), 2.06$ (dd, $J=15.1,7.4 \mathrm{~Hz}, 2 \mathrm{H}), 1.77-1.70$ (m, $4 \mathrm{H}), 1.67$ (s, $3 \mathrm{H}$ ), 1.59 (s, $3 \mathrm{H}), 1.29$ (t, $J=7.1 \mathrm{~Hz}, 3 \mathrm{H}) ;{ }^{13} \mathrm{C}$ NMR $\left(125 \mathrm{MHz}, \mathrm{CDCl}_{3}\right) \delta 170.0,144.4,132.2$, $126.4,123.4,114.2,108.2,64.3,60.0,35.6,35.6,29.8,28.9,27.9,27.6,25.6,17.5,14.2$; HRMS (Mixed+) calcd for $\mathrm{C}_{18} \mathrm{H}_{29} \mathrm{O}_{4}^{+}\left[\mathrm{M}+\mathrm{H}^{+}\right] 309.2060$, found 309.2059.
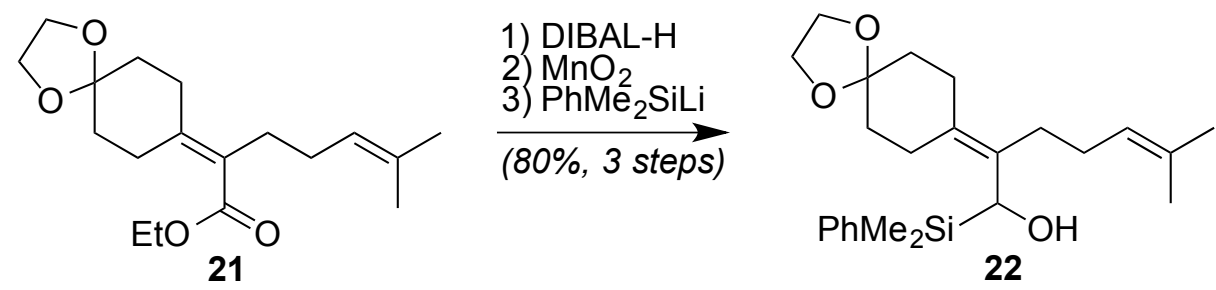

$\boldsymbol{\alpha}$-Silyl Alcohol 22. To a solution of ester 21 (2.42 g, $7.85 \mathrm{mmol}, 1.0$ equiv) in $\mathrm{CH}_{2} \mathrm{Cl}_{2}(25 \mathrm{~mL})$ at $-78{ }^{\circ} \mathrm{C}$ was added DIBAL-H (1.0 $\mathrm{M}$ in hexanes, $23.5 \mathrm{~mL}, 23.5 \mathrm{mmol}, 3.0$ equiv) dropwise over the course of $10 \mathrm{~min}$. Once the addition was complete, the reaction contents were stirred at $-78{ }^{\circ} \mathrm{C}$ for $2 \mathrm{~h}$. Upon completion, the reaction mixture was quenched by the slow and careful addition of $\mathrm{H}_{2} \mathrm{O}(25 \mathrm{~mL})$ and then were warmed to $23{ }^{\circ} \mathrm{C}$, at which time $\mathrm{CH}_{2} \mathrm{Cl}_{2}(25 \mathrm{~mL})$ and saturated aqueous Rochelle's salt $(70 \mathrm{~mL})$ were added sequentially. The resultant biphasic mixture was stirred vigorously until clear phase separation was observed. The reaction contents were then poured into a separatory funnel and the layers were separated. The aqueous layer was extracted with $\mathrm{CH}_{2} \mathrm{Cl}_{2}(3 \times 20 \mathrm{~mL})$ and the combined organic layers were then washed with brine $(50 \mathrm{~mL})$, dried $\left(\mathrm{MgSO}_{4}\right)$, filtered, and concentrated to give the desired crude alcohol as a colorless oil $\left(\mathrm{R}_{f}=0.29\right.$, silica 
gel, hexanes/EtOAc, 7/3). Pressing forward without any additional purification, the so-formed crude alcohol (7.85 mmol assumed, 1.0 equiv) was dissolved in $\mathrm{CH}_{2} \mathrm{Cl}_{2}(25 \mathrm{~mL})$ and $\mathrm{MnO}_{2}$ (3.41 g, $39.3 \mathrm{mmol}, 5.0$ equiv) was added at $23{ }^{\circ} \mathrm{C}$. After stirring the resultant slurry vigorously at $23{ }^{\circ} \mathrm{C}$ for $8 \mathrm{~h}$, a second portion of $\mathrm{MnO}_{2}$ (3.41 g, $39.3 \mathrm{mmol}, 5.0$ equiv) was added and the reaction contents were stirred at $23{ }^{\circ} \mathrm{C}$ for a further $8 \mathrm{~h}$. Upon completion, the reaction contents were filtered through Celite, with the filter cake washed thoroughly with $\mathrm{CH}_{2} \mathrm{Cl}_{2}(4 \times 6 \mathrm{~mL})$. The combined organic filtrate was then concentrated to afford the desired crude aldehyde as a pale yellow oil $\left(\mathrm{R}_{f}=0.50\right.$, silica gel, hexanes/EtOAc, $7 / 3$ ). Next, the so-obtained crude aldehyde (7.85 mmol assumed, 1.0 equiv) was dissolved in THF $(24 \mathrm{~mL})$, cooled to $-78{ }^{\circ} \mathrm{C}$, and a solution of $\mathrm{PhMe}_{2} \mathrm{SiLi}(0.75 \mathrm{M}$ in THF, $13.6 \mathrm{~mL}$, $10.2 \mathrm{mmol}, 1.3$ equiv) was added dropwise over the course of $30 \mathrm{~min}^{2}$ Once the addition was complete, the reaction was stirred at $-78{ }^{\circ} \mathrm{C}$ for a further $30 \mathrm{~min}$. Upon completion, the reaction contents were quenched by the addition of a half-saturated aqueous solution of $\mathrm{NH}_{4} \mathrm{Cl}(50 \mathrm{~mL})$, warmed to $23{ }^{\circ} \mathrm{C}$, and poured into a separatory funnel. The layers were separated, and the aqueous layer was extracted with EtOAc $(3 \times 20 \mathrm{~mL})$. The combined organic layers were then washed with brine $(40 \mathrm{~mL})$, dried $\left(\mathrm{MgSO}_{4}\right)$, filtered, and concentrated. The resultant residue was purified by flash column chromatography (silica gel, hexanes/EtOAc, 15/1) to afford $22(2.49 \mathrm{~g}, 6.22 \mathrm{mmol}, 80 \%$ yield over 3 steps $)$ as a white solid. 22: $\mathrm{R}_{f}=0.58$ (silica gel, hexanes/EtOAc, 7/3); IR (film) $v_{\max } 3475,2960,2880$, 1428, 1247, 1115, 1087, 1034, 916, 834, 818, 782, 736, $701 \mathrm{~cm}^{-1} ;{ }^{1} \mathrm{H}$ NMR $(500 \mathrm{MHz}$, $\left.\mathrm{CDCl}_{3}\right) \delta 7.55(\mathrm{dd}, J=7.4,1.8 \mathrm{~Hz}, 2 \mathrm{H}), 7.40-7.31(\mathrm{~m}, 3 \mathrm{H}), 5.13(\mathrm{~s}, 1 \mathrm{H}), 4.63(\mathrm{~s}, 1 \mathrm{H}), 3.94$ (d, $J=1.1 \mathrm{~Hz}, 4 \mathrm{H}), 2.38-2.27(\mathrm{~m}, 2 \mathrm{H}), 2.27-2.18(\mathrm{~m}, 1 \mathrm{H}), 2.12-1.93(\mathrm{~m}, 5 \mathrm{H}), 1.68(\mathrm{~s}, 3$ H), 1.67-1.63 (m, $2 \mathrm{H}), 1.57$ (s, $3 \mathrm{H}), 1.56-1.49$ (m, $2 \mathrm{H}), 1.42-1.35(\mathrm{~m}, 1 \mathrm{H}), 0.36(\mathrm{~s}, 3 \mathrm{H})$, $0.30(\mathrm{~s}, 3 \mathrm{H}) .{ }^{13} \mathrm{C} \mathrm{NMR}\left(125 \mathrm{MHz}, \mathrm{CDCl}_{3}\right) \delta 137.2,134.1,132.4,132.2,131.1,129.2,127.8$, 124.5, 108.8, 67.9, 64.2, 64.2, 35.9, 35.6, 29.8, 29.6, 27.6, 27.1, 25.7, 17.7, -4.2, -4.7; HRMS (Mixed+) calcd for $\mathrm{C}_{24} \mathrm{H}_{36} \mathrm{O}_{3} \mathrm{SiNa}^{+}\left[\mathrm{M}+\mathrm{Na}^{+}\right]$423.2326, found 423.2320.
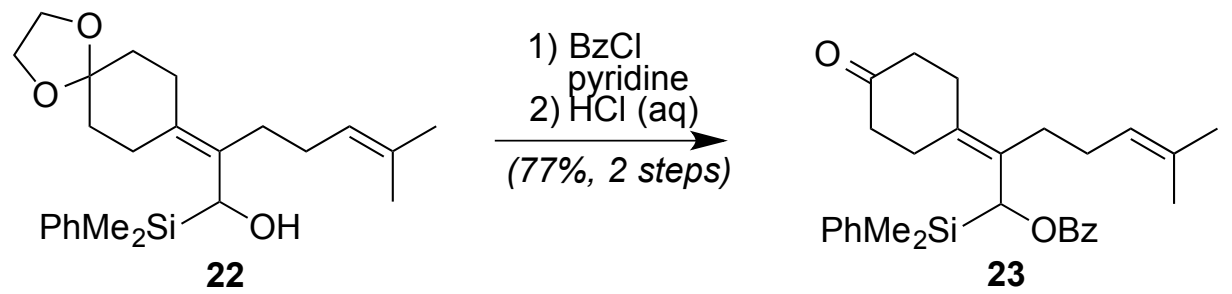

Polyene 23. To a solution of alcohol 23 (1.39 g, $3.48 \mathrm{mmol}, 1.0$ equiv) in $\mathrm{CH}_{2} \mathrm{Cl}_{2}$ $(12 \mathrm{~mL})$ at $23{ }^{\circ} \mathrm{C}$ was added pyridine $(1.65 \mathrm{~g}, 1.69 \mathrm{~mL}, 20.9 \mathrm{mmol}, 6.0$ equiv), and the resultant mixture was then cooled to $0{ }^{\circ} \mathrm{C}$. Next, benzoyl chloride $(1.47 \mathrm{~g}, 1.21 \mathrm{~mL}, 10.4$ mmol, 3.0 equiv) was added dropwise over the course of $1 \mathrm{~min}$. The reaction contents were then warmed to $23{ }^{\circ} \mathrm{C}$ over the course of $30 \mathrm{~min}$ and stirred at $23{ }^{\circ} \mathrm{C}$ for an additional $8 \mathrm{~h}$. Upon completion, the reaction was quenched with saturated aqueous $\mathrm{NaHCO}_{3}(20 \mathrm{~mL})$, poured into a separatory funnel, and the layers were separated. The aqueous layer was extracted with $\mathrm{CH}_{2} \mathrm{Cl}_{2}(3 \times 10 \mathrm{~mL})$, and the combined organic layers were washed sequentially with saturated aqueous $\mathrm{CuSO}_{4}(30 \mathrm{~mL})$ and brine $(30 \mathrm{~mL})$, dried $\left(\mathrm{MgSO}_{4}\right)$, filtered, and concentrated. The resultant residue was purified by flash column chromatography (silica gel, hexanes/EtOAc, 12/1) to give an inseparable mixture of the 
desired benzoate intermediate along with impurities as a pale yellow oil $\left(\mathrm{R}_{f}=0.62\right.$, silica gel, hexanes/EtOAc, 7/3). Pressing forward, the so-obtained mixture of the desired benzoate intermediate and the associated impurity were dissolved in acetone $(60 \mathrm{~mL})$ and $5 \%$ aqueous $\mathrm{HCl}(30 \mathrm{~mL})$ was added dropwise over the course of $5 \mathrm{~min}$ at $23{ }^{\circ} \mathrm{C}$. The resultant slightly cloudy solution was then stirred at $23{ }^{\circ} \mathrm{C}$ for $8 \mathrm{~h}$. Upon completion, the reaction contents were quenched by the slow addition of saturated aqueous $\mathrm{NaHCO}_{3}(40 \mathrm{~mL})$, poured into a separatory funnel, and the layers were separated. The aqueous layer was extracted with EtOAc $(3 \times 50 \mathrm{~mL})$, and the combined organic layers were dried $\left(\mathrm{MgSO}_{4}\right)$, filtered, and concentrated. The resultant residue was purified by flash column chromatography (silica gel, hexanes/EtOAc, 20/1 $\rightarrow 12 / 1)$ to afford polyene $23(1.27 \mathrm{~g}, 80 \%$ yield over 2 steps) as a white solid. 23: $\mathrm{R}_{f}=0.60$ (silica gel, hexanes/EtOAc, 7/3); IR (film) $v_{\max } 2962,1716,1271,1108$, 834, 816, $711 \mathrm{~cm}^{-1} ;{ }^{1} \mathrm{H}$ NMR $\left(500 \mathrm{MHz}, \mathrm{CDCl}_{3}\right) \delta 8.04(\mathrm{~d}, J=7.2 \mathrm{~Hz}, 2 \mathrm{H}), 7.61-7.50(\mathrm{~m}, 3$ $\mathrm{H}), 7.45(\mathrm{t}, J=7.7 \mathrm{~Hz}, 2 \mathrm{H}), 7.40-7.30(\mathrm{~m}, 3 \mathrm{H}), 6.02(\mathrm{~s}, 1 \mathrm{H}), 5.01(\mathrm{t}, J=7.0 \mathrm{~Hz}, 1 \mathrm{H})$, 2.64-2.53 (m, $1 \mathrm{H}), 2.49$ (t, $J=6.7 \mathrm{~Hz}, 2 \mathrm{H}), 2.39-2.30(\mathrm{~m}, 1 \mathrm{H}), 2.29-2.18(\mathrm{~m}, 2 \mathrm{H}), 2.13(\mathrm{t}$, $J=8.3 \mathrm{~Hz}, 2 \mathrm{H}), 2.08-1.83(\mathrm{~m}, 4 \mathrm{H}), 1.59$ (s, $3 \mathrm{H}), 1.36$ (s, $3 \mathrm{H}), 0.46$ (s, $3 \mathrm{H}), 0.44$ (s, $3 \mathrm{H})$;

${ }^{13} \mathrm{C} \mathrm{NMR}\left(125 \mathrm{MHz}, \mathrm{CDCl}_{3}\right) \delta 212.1,166.4,135.7,134.1,132.8,131.8,131.1,130.4,129.7$, $129.5,129.5,128.4,127.8,123.9,70.6,40.2,39.8,30.9,28.6,27.4,27.4,25.6,17.4,-4.2$; HRMS (ESI+) calcd for $\mathrm{C}_{29} \mathrm{H}_{36} \mathrm{O}_{3} \mathrm{SiNa}^{+}\left[\mathrm{M}+\mathrm{Na}^{+}\right]$483.2326, found 483.2321.

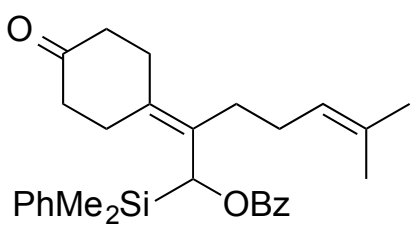

23

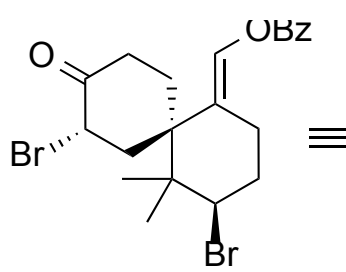

24

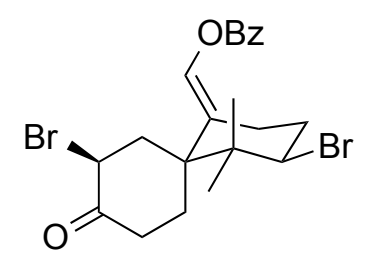

24

Dibromide 24. To a stirred solution of polyene $23(0.317 \mathrm{~g}, 0.688 \mathrm{mmol}, 1.0$ equiv) in $\mathrm{CH}_{3} \mathrm{NO}_{2}(68 \mathrm{~mL})$ at $23{ }^{\circ} \mathrm{C}$ was quickly added a solution of $\mathrm{BDSB}(0.748 \mathrm{~g}, 1.38 \mathrm{mmol}, 2.0$ equiv) in $\mathrm{CH}_{3} \mathrm{NO}_{2}(1 \mathrm{~mL})$, and the resultant mixture was stirred for $15 \mathrm{~min}$ at $23{ }^{\circ} \mathrm{C}$. Upon completion, the reaction contents were quenched by the sequential addition of $5 \%$ aqueous $\mathrm{Na}_{2} \mathrm{SO}_{3}(35 \mathrm{~mL})$ and $5 \%$ aqueous $\mathrm{NaHCO}_{3}(35 \mathrm{~mL})$ and the resultant mixture was vigorously stirred for additional $30 \mathrm{~min}$ at $23{ }^{\circ} \mathrm{C}$ before being poured into a separatory funnel and separating the layers. The aqueous layer was then extracted with $\mathrm{CH}_{2} \mathrm{Cl}_{2}(3 \times 15 \mathrm{~mL})$ and the combined organic layers were dried $\left(\mathrm{MgSO}_{4}\right)$, filtered, concentrated. The resultant residue was purified by flash column chromatography (silica gel, hexanes/EtOAc, 10/1) to afford 24 (0.129 g, 39\% yield, 6:1 inseparable mixture of $\mathbf{2 4}$ and what is believed a diastereomer) as a light yellowish solid. Recrystallization of this material from benzene $/ \mathrm{CHCl}_{3}$ afforded crystals of suitable quality for X-ray diffraction, with the resultant crystal structure shown below in Figure S1. [Note: removal of all residual $\mathrm{CH}_{3} \mathrm{NO}_{2}$ prior to column chromatography is crucial for achieving the desired level of purification]. 24: $\mathrm{R}_{f}=$ 0.55 (silica gel, hexanes/EtOAc, 7/3); m.p. > $150{ }^{\circ} \mathrm{C}$ (decompose); IR (film) $v_{\max } 2976,1730$, 1451, 1266, 1134, 1118, 1066, 733, $710 \mathrm{~cm}^{-1} ;{ }^{1} \mathrm{H}$ NMR $\left(500 \mathrm{MHz}, \mathrm{CDCl}_{3}\right) \delta 8.13-8.07$ (m, 2 H), $7.64(\mathrm{t}, J=7.4 \mathrm{~Hz}, 1 \mathrm{H}), 7.51(\mathrm{t}, J=7.8 \mathrm{~Hz}, 2 \mathrm{H}), 7.39(\mathrm{~s}, 1 \mathrm{H}), 4.96(\mathrm{dd}, J=12.2,6.7 \mathrm{~Hz}$, $1 \mathrm{H}), 4.52$ (dd, $J=12.0,4.5 \mathrm{~Hz}, 1 \mathrm{H}), 3.10-3.00(\mathrm{~m}, 1 \mathrm{H}), 2.93-2.83$ (m, $1 \mathrm{H}), 2.57$ (dt, $J=$ 
14.2, 3.3 Hz, $1 \mathrm{H}), 2.53-2.45$ (m, $1 \mathrm{H}), 2.45-2.38(\mathrm{~m}, 1 \mathrm{H}), 2.38-2.30$ (m, $2 \mathrm{H}), 2.14-2.02$ (m, $3 \mathrm{H}), 1.18(\mathrm{~s}, 3 \mathrm{H}), 1.09$ (s, $3 \mathrm{H}) ;{ }^{13} \mathrm{C}$ NMR $\left(125 \mathrm{MHz}, \mathrm{CDCl}_{3}\right) \delta 200.8,163.7,133.9,133.0$, 129.9, 128.7, 128.7, 123.2, 62.8, 52.2, 48.6, 44.2, 41.7, 36.2, 34.4, 28.8, 23.6, 23.4, 17.9; HRMS (APCI+) calcd for $\mathrm{C}_{21} \mathrm{H}_{25} \mathrm{Br}_{2} \mathrm{O}_{3}{ }^{+}\left[\mathrm{M}+\mathrm{H}^{+}\right]$485.0144, found 485.0144.

Figure S1. ORTEP representation of Dibromide 24.

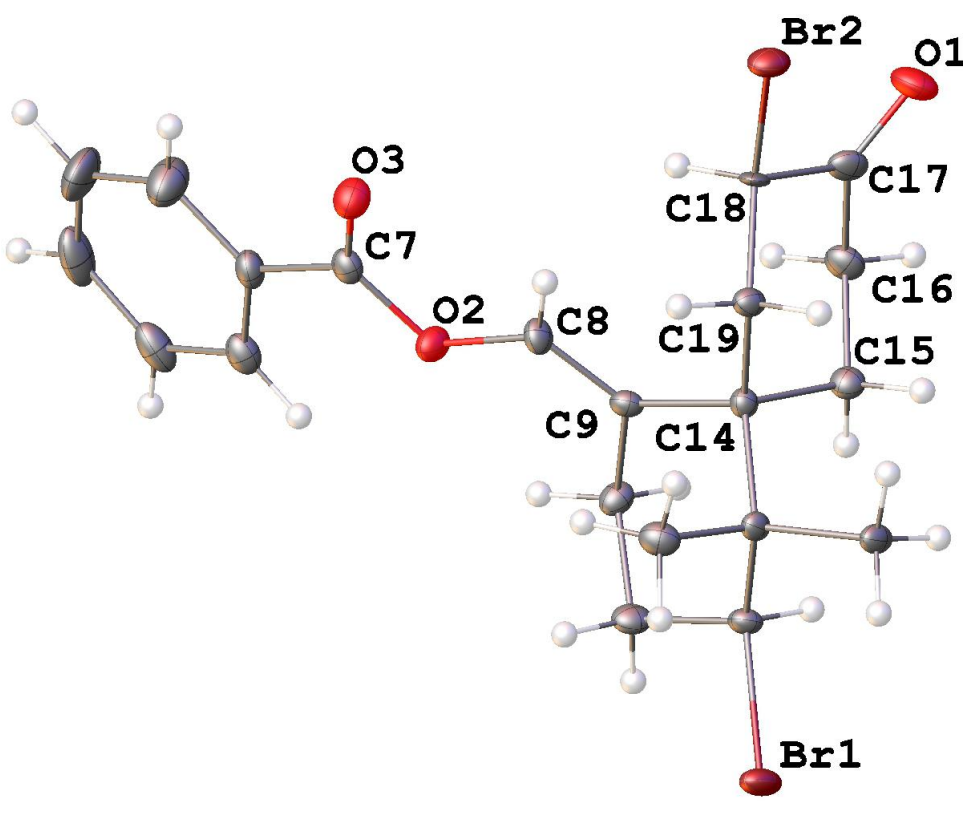<smiles>O=C1CCC2(CC1Br)C(Br)C(Br)C2COCCO</smiles>

24

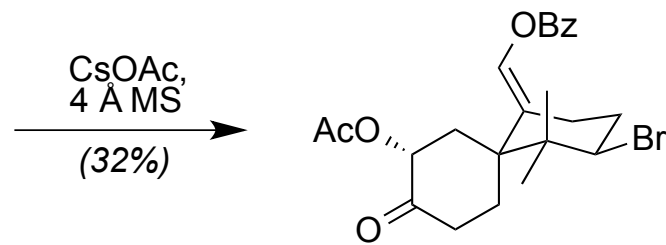

25

a-Acetoxy Ketone 25. A flame-dried flask was charged with a solution of compound 24 (55.0 mg, $0.114 \mathrm{mmol}, 1.0$ equiv) in DMF $(1.5 \mathrm{~mL})$, and then activated $4 \AA$ molecular sieves $(200 \mathrm{mg})$ and $\mathrm{CsOAc}(0.11 \mathrm{~g}, 0.57 \mathrm{mmol}, 5.0$ equiv) were added sequentially at $23{ }^{\circ} \mathrm{C}$. The reaction contents were then warmed to $40{ }^{\circ} \mathrm{C}$ and stirred at this temperature for $2 \mathrm{~h}$. Upon completion, the reaction contents were cooled, and $\mathrm{H}_{2} \mathrm{O}(3 \mathrm{~mL})$ and $\mathrm{Et}_{2} \mathrm{O}(3 \mathrm{~mL})$ were added. The $4 \AA$ molecular sieves were then removed by filtration, washing with $\mathrm{Et}_{2} \mathrm{O}(2 \times 0.5 \mathrm{~mL})$. The filtrate was then poured into a separatory funnel and the layers were separated. The aqueous layer was extracted with $\mathrm{Et}_{2} \mathrm{O}(3 \times 3 \mathrm{~mL})$ and the combined organic layers were washed with $\mathrm{H}_{2} \mathrm{O}(2 \mathrm{~mL})$ and brine $(3 \mathrm{~mL})$, dried $\left(\mathrm{MgSO}_{4}\right)$, filtered, and concentrated. The resultant residue was purified by flash column chromatography (silica gel, hexanes/EtOAc, 5/1) to afford $\mathbf{2 5}(16.6 \mathrm{mg}, 32 \%$ yield) as a white solid. 25: $\mathrm{R}_{f}=0.38$ (silica gel, hexanes/EtOAc, 7/3); IR (film) $v_{\max } 2977,1734$ (br), 1451, 
1375, 1267, 1178, 1119, 1070, 735, $710 \mathrm{~cm}^{-1} ;{ }^{1} \mathrm{H}$ NMR (400 MHz, $\left.\mathrm{CDCl}_{3}\right) \delta 8.10-8.01(\mathrm{~m}, 2$ H), 7.63-7.57 (m, 1 H), 7.51-7.44 (m, $2 \mathrm{H}), 7.17$ (d, $J=1.3 \mathrm{~Hz}, 1 \mathrm{H}), 5.14$ (dd, $J=12.8,6.4$ $\mathrm{Hz}, 1 \mathrm{H}), 4.59$ (dd, $J=12.5,4.4 \mathrm{~Hz}, 1 \mathrm{H}), 3.01-2.91(\mathrm{~m}, 1 \mathrm{H}), 2.83(\mathrm{dd}, J=14.7,3.5 \mathrm{~Hz}, 1$ $\mathrm{H}), 2.63(\mathrm{~d}, J=14.7 \mathrm{~Hz}, 1 \mathrm{H}), 2.35-2.25(\mathrm{~m}, 2 \mathrm{H}), 2.14(\mathrm{~s}, 3 \mathrm{H}), 2.12-2.06(\mathrm{~m}, 1 \mathrm{H}), 2.04(\mathrm{~d}$, $J=3.8 \mathrm{~Hz}, 1 \mathrm{H}), 2.02-1.98(\mathrm{~m}, 1 \mathrm{H}), 1.96(\mathrm{dd}, J=4.9,1.7 \mathrm{~Hz}, 1 \mathrm{H}), 1.77-1.65(\mathrm{~m}, 1 \mathrm{H})$, 1.24 (s, $3 \mathrm{H}), 1.03$ (s, $3 \mathrm{H}) ;{ }^{13} \mathrm{C}$ NMR $\left(125 \mathrm{MHz}, \mathrm{CDCl}_{3}\right) \delta 202.8,170.1,163.3,134.8,133.5$, 129.9, 129.1, 128.6, 124.4, 75.9, 62.8, 50.8, 44.9, 43.6, 34.0, 26.6, 26.2, 23.9, 23.4, 20.7, 17.8; HRMS (Mixed+) calcd for $\mathrm{C}_{23} \mathrm{H}_{28} \mathrm{BrO}_{5}^{+}\left[\mathrm{M}+\mathrm{H}^{+}\right] 463.1115$, found 463.1114 .
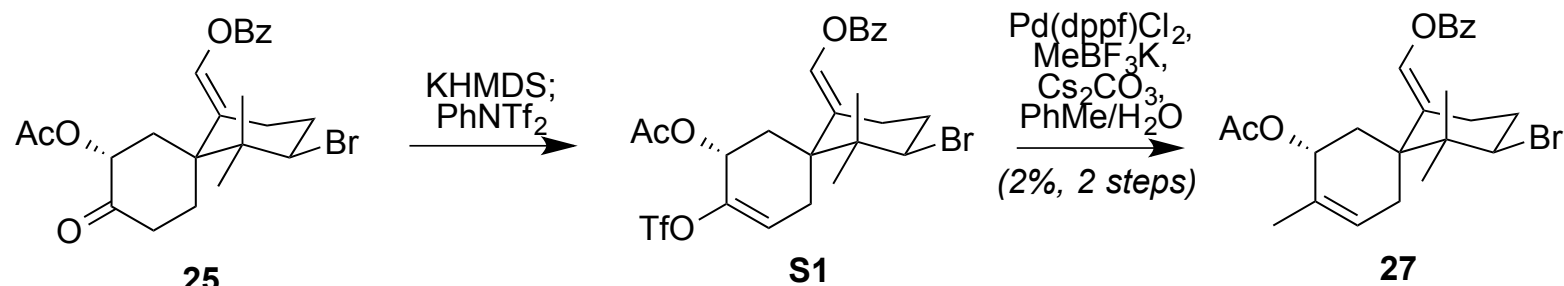

Alkene 27. A flame-dried flask was charged with a solution of compound 25 (59.0 $\mathrm{mg}, 0.127 \mathrm{mmol}, 1.0$ equiv) in THF $(2 \mathrm{~mL})$. After cooling the reaction contents to $-78{ }^{\circ} \mathrm{C}$, KHMDS ( $0.5 \mathrm{M}$ in toluene, $0.29 \mathrm{~mL}, 0.145 \mathrm{mmol}, 1.15$ equiv) was added dropwise over the course of $2 \mathrm{~min}$ and the resultant mixture was stirred at $-78{ }^{\circ} \mathrm{C}$ for $30 \mathrm{~min}$. Next, solid PhNTf $_{2}$ (60.6 mg, $0.166 \mathrm{mmol}, 1.3$ equiv) was added in a single portion and the reaction contents were stirred at $-78{ }^{\circ} \mathrm{C}$ for $3 \mathrm{~h}$. Upon completion, the reaction mixture was quenched by the addition of a half-saturated aqueous solution of $\mathrm{NH}_{4} \mathrm{Cl}(3 \mathrm{~mL})$, poured into a separatory funnel, and the layers were separated. The aqueous layer was extracted with EtOAc $(3 \times 3 \mathrm{~mL})$ and the combined organic layers were dried $\left(\mathrm{MgSO}_{4}\right)$, filtered, and concentrated. The resultant residue was purified by flash column chromatography (silica gel, hexanes/EtOAc, 8/1) to give the desired vinyl triflate (21.6 mg, 29\% yield) as a white gel $\left(\mathrm{R}_{f}=0.50\right.$, silica gel, hexanes/EtOAc, $\left.7 / 3\right)$. Next, the vinyl triflate $(21.6 \mathrm{mg}, 0.036 \mathrm{mmol}$, 1.0 equiv) was dissolved in toluene $(0.8 \mathrm{~mL}), \mathrm{H}_{2} \mathrm{O}(0.1 \mathrm{~mL})$ was added at $23{ }^{\circ} \mathrm{C}$, and the mixture was degassed for 10 min by bubbling argon directly through the solution. $\mathrm{MeBF}_{3} \mathrm{~K}$ (6.6 mg, $0.054 \mathrm{mmol}, 1.5$ equiv), $\mathrm{Pd}(\mathrm{dppf}) \mathrm{Cl}_{2}$ ( $3.0 \mathrm{mg}, 0.003 \mathrm{mmol}, 0.1$ equiv), and $\mathrm{Cs}_{2} \mathrm{CO}_{3}$ (35.5 mg, $0.108 \mathrm{mmol}, 3.0$ equiv) were then added sequentially at $23{ }^{\circ} \mathrm{C}$. The reaction contents were then warmed to $80{ }^{\circ} \mathrm{C}$ and stirred at that temperature for $8 \mathrm{~h}$. Upon completion, the reaction contents were cooled and then quenched by the addition of $\mathrm{H}_{2} \mathrm{O}(3$ $\mathrm{mL}$ ), poured into a separatory funnel, and the layers were separated. The aqueous layer was extracted with EtOAc $(3 \times 3 \mathrm{~mL})$, and the combined organic layers were washed by brine $(3$ $\mathrm{mL})$, dried $\left(\mathrm{MgSO}_{4}\right)$, filtered, and concentrated. The resultant residue was purified by preparative thin-layer chromatography (silica gel, hexanes/EtOAc, 7/3) to afford $27(1.5 \mathrm{mg}$, $9 \%$ yield, $2 \%$ yield over 2 steps) as a colorless gel along with recovered starting vinyl triflate $(11.0 \mathrm{mg}, 50 \%$ recovery, $18 \%$ yield, $4 \%$ yield over 2 steps based on recovered starting material). 27: $\mathrm{R}_{f}=0.54$ (silica gel, hexanes/EtOAc, 7/3); IR (film) $v_{\max } 2923,2852,1737$, 1730, 1265, 1244, 1119, 1022, $710 \mathrm{~cm}^{-1}$; ${ }^{1} \mathrm{H}$ NMR (400 MHz, $\left.\mathrm{CDCl}_{3}\right) \delta 8.13-8.05(\mathrm{~m}, 2 \mathrm{H})$, 7.64-7.57 (m, $1 \mathrm{H}), 7.51-7.45(\mathrm{~m}, 2 \mathrm{H}), 7.10(\mathrm{~d}, J=1.8 \mathrm{~Hz}, 1 \mathrm{H}), 5.51(\mathrm{~d}, J=1.4 \mathrm{~Hz}, 1 \mathrm{H})$, $5.28(\mathrm{dd}, J=10.0,5.6 \mathrm{~Hz}, 1 \mathrm{H}), 4.56(\mathrm{dd}, J=12.2,4.3 \mathrm{~Hz}, 1 \mathrm{H}), 3.04-2.92(\mathrm{~m}, 1 \mathrm{H})$, 
2.29-2.19 (m, $2 \mathrm{H}), 2.16-2.09$ (m, $2 \mathrm{H}), 2.07$ (s, $3 \mathrm{H}), 1.98-1.89$ (m, $2 \mathrm{H}), 1.86-1.79$ (m, 1 $\mathrm{H}), 1.75(\mathrm{~s}, 3 \mathrm{H}), 1.12(\mathrm{~s}, 3 \mathrm{H}), 1.05(\mathrm{~s}, 3 \mathrm{H}) ;{ }^{13} \mathrm{C} \mathrm{NMR}\left(175 \mathrm{MHz}, \mathrm{CDCl}_{3}\right) \delta 171.1,163.6$, 137.3, 134.1, 133.5, 129.8, 128.6, 127.6, 125.8, 72.0, 63.4, 49.0, 42.8, 33.0, 25.8, 25.2, 24.6, 23.1, 21.1, 19.5, 18.1; HRMS (ESI+) calcd for $\mathrm{C}_{24} \mathrm{H}_{29} \mathrm{BrO}_{4} \mathrm{Na}^{+}\left[\mathrm{M}+\mathrm{Na}^{+}\right]$483.1141, found 483.1143 .

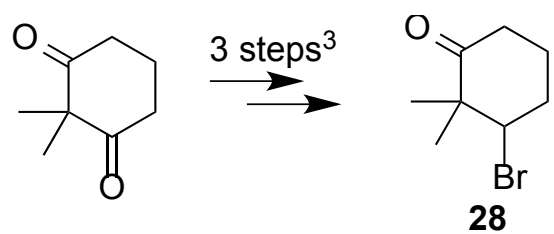

Bromo Ketone 28. Prepared according to the method reported by Djerassi. ${ }^{3} \quad$ 28: $\mathrm{R}_{f}$ $=0.46$ (silica gel, hexanes/EtOAc, 4/1); IR (film) $v_{\max }$ 2948, 2871, 1712, 1466, 1450, 1385, 1366, 1312, 1260, 1222, 1141, 1104, 990, 936, 916, 841, 805, 728, $563 \mathrm{~cm}^{-1} ;{ }^{1} \mathrm{H}$ NMR (500 $\left.\mathrm{MHz}, \mathrm{CDCl}_{3}\right) \delta 4.15(\mathrm{dd}, J=9.9,3.7 \mathrm{~Hz}, 1 \mathrm{H}), 2.57-2.46(\mathrm{~m}, 1 \mathrm{H}), 2.40-2.30(\mathrm{~m}, 2 \mathrm{H})$, 2.29-2.18 (m, $1 \mathrm{H}), 2.15-2.03(\mathrm{~m}, 1 \mathrm{H}), 1.73-1.59(\mathrm{~m}, 1 \mathrm{H}), 1.22(\mathrm{~s}, 6 \mathrm{H}) ;{ }^{13} \mathrm{C} \mathrm{NMR}(125$ $\left.\mathrm{MHz}, \mathrm{CDCl}_{3}\right) \delta 210.5,62.9,51.6,36.9,32.2,24.0,23.9,22.5$; HRMS (Mixed + ) calcd for $\mathrm{C}_{8} \mathrm{H}_{13} \mathrm{BrO}^{+}\left[\mathrm{M}^{+}\right]$205.0223, found 205.0206.<smiles>CC1(C)C(=O)CCCC1Br</smiles>

28

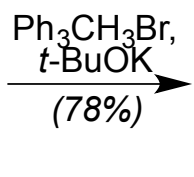

1) $\mathrm{SeO}_{2}$

$t$-BuÖOH

2) Dess-Martin $\underset{(54 \%, 2 \text { steps })}{\stackrel{\text { periodinane }}{\longrightarrow}}$

S2<smiles>C=C1C(=O)CCC(Br)C1(C)C</smiles>

29

Bromo Alkene S2. To a flame-dried flask was added $\mathrm{Ph}_{3} \mathrm{PCH}_{3} \mathrm{Br}(2.44 \mathrm{~g}, 6.84$ mmol, 2.0 equiv) and benzene $(6 \mathrm{~mL})$. Next, solid $t$-BuOK $(0.575 \mathrm{~g}, 5.13 \mathrm{mmol}, 1.5$ equiv $)$ was added at $23{ }^{\circ} \mathrm{C}$ and the resultant mixture was then warmed to $80{ }^{\circ} \mathrm{C}$ and stirred at that temperature for $1 \mathrm{~h}$. A solution of ketone $28(0.702 \mathrm{~g}, 3.42 \mathrm{mmol}, 1.0$ equiv) in benzene ( 2 $\mathrm{mL}$ ) was then added dropwise over the course of $1 \mathrm{~min}$ and the resultant reaction contents were stirred at $80^{\circ} \mathrm{C}$ for an additional $10 \mathrm{~min}$. Upon completion, the reaction contents were cooled, diluted with hexanes $(20 \mathrm{~mL})$, and filtered. The resultant filtrate was concentrated directly and the resultant residue was purified by flash column chromatography (silica gel, hexanes) to afford alkene $\mathbf{S 2}(0.540 \mathrm{~g}, 78 \%$ yield $)$ as a colorless oil. [Note: this compound is volatile under long-term exposure to high vacuum]. S1: $\mathrm{R}_{f}=0.80$ (silica gel, hexanes/EtOAc, 4/1); IR (film) $v_{\max }$ 2969, 2942, 2859, 1448, 1380, 1222, 1138, 901, 728, $607 \mathrm{~cm}^{-1}$; ${ }^{1} \mathrm{H}$ NMR $\left(500 \mathrm{MHz}, \mathrm{CDCl}_{3}\right) \delta 4.79(\mathrm{~s}, 1 \mathrm{H}), 4.78(\mathrm{~s}, 1 \mathrm{H}), 4.04(\mathrm{dd}, J=10.3,4.1$ $\mathrm{Hz}, 1 \mathrm{H}), 2.33-2.25(\mathrm{~m}, 1 \mathrm{H}), 2.25-2.18(\mathrm{~m}, 2 \mathrm{H}), 2.17-2.08(\mathrm{~m}, 1 \mathrm{H}), 1.88-1.79(\mathrm{~m}, 1 \mathrm{H})$, $1.48-1.37(\mathrm{~m}, 1 \mathrm{H}), 1.26(\mathrm{~s}, 3 \mathrm{H}), 1.19(\mathrm{~s}, 3 \mathrm{H}) ;{ }^{13} \mathrm{C} \mathrm{NMR}\left(125 \mathrm{MHz}, \mathrm{CDCl}_{3}\right) \delta 153.0,108.7$, $66.8,42.4,34.0,32.0,27.4,27.1,23.2$; HRMS was attempted but no satisfactory ionization was observed. 
Bromo Enone 29. To a solution of compound $\mathbf{S 2}(0.390 \mathrm{~g}, 1.92 \mathrm{mmol}, 1.0$ equiv) in $\mathrm{CHCl}_{3}(12 \mathrm{~mL})$ at $23{ }^{\circ} \mathrm{C}$ was added solid $\mathrm{SeO}_{2}(0.213 \mathrm{~g}, 1.92 \mathrm{mmol}, 1.0$ equiv) followed by $t$-BuOOH $(1.04 \mathrm{~mL}, 5.5 \mathrm{M}$ in nonane, $5.76 \mathrm{mmol}, 3.0$ equiv). The resultant mixture was then warmed to $55^{\circ} \mathrm{C}$ and stirred for $11 \mathrm{~h}$. Upon completion, the reaction was concentrated directly under reduced pressure and the resultant residue was purified by flash column chromatography (silica gel, hexanes/EtOAc, 5/1) to give the desired allylic alcohol $(0.295 \mathrm{~g}$, $70 \%$ yield $)$ as a light yellow oil $\left(\mathrm{R}_{f}=0.24\right.$, silica gel, hexanes/EtOAc, $\left.4 / 1\right)$. Next, the newly prepared allylic alcohol (0.295 g, $1.35 \mathrm{mmol}, 1.0$ equiv) was dissolved in $\mathrm{CH}_{2} \mathrm{Cl}_{2}(8 \mathrm{~mL})$ and then $\mathrm{NaHCO}_{3}(0.339 \mathrm{~g}, 4.04 \mathrm{mmol}, 3.0$ equiv) and Dess-Martin periodinane $(0.837 \mathrm{~g}, 2.02$ mmol, 1.5 equiv) were added sequentially at $23{ }^{\circ} \mathrm{C}$. The resultant mixture was stirred at 23 ${ }^{\circ} \mathrm{C}$ for $2 \mathrm{~h}$. Upon completion, the reaction contents were quenched with $10 \%$ aqueous $\mathrm{Na}_{2} \mathrm{~S}_{2} \mathrm{O}_{3}(15 \mathrm{~mL})$, poured into a separatory funnel, and the layers were separated. The aqueous layer was extracted with $\mathrm{CH}_{2} \mathrm{Cl}_{2}(3 \times 5 \mathrm{~mL})$ and the combined organic layers were washed with brine $(10 \mathrm{~mL})$, dried $\left(\mathrm{MgSO}_{4}\right)$, filtered, and concentrated. The resultant residue was purified by flash column chromatography (silica gel, hexanes/EtOAc, 20/1) to afford $29(0.223 \mathrm{~g}, 76 \%$ yield, 54\% yield over 2 steps) as a colorless oil. [Note: this compound could homo-dimerize upon long-term exposure to high vacuum]. ${ }^{4}$ 29: IR (film) $v_{\max } 2956,2930,2886,2857,1699,1472,1464,1257,1092,836,775 \mathrm{~cm}^{-1} ;{ }^{1} \mathrm{H}$ NMR (500 $\left.\mathrm{MHz}, \mathrm{CDCl}_{3}\right) \delta 5.84(\mathrm{~s}, 1 \mathrm{H}), 5.28(\mathrm{~s}, 1 \mathrm{H}), 4.31(\mathrm{dd}, J=5.6,2.9 \mathrm{~Hz}, 1 \mathrm{H}), 2.86-2.75(\mathrm{~m}, 1$ $\mathrm{H}), 2.60-2.45$ (m, $2 \mathrm{H}), 2.39-2.29$ (m, $1 \mathrm{H}), 1.29$ (s, $3 \mathrm{H}), 1.26$ (s, $3 \mathrm{H}) ;{ }^{13} \mathrm{C}$ NMR $(125 \mathrm{MHz}$, $\left.\mathrm{CDCl}_{3}\right) \delta 200.9,151.8,119.0,61.7,43.2,37.2,29.6,27.8,26.2$; HRMS (Mixed + ) calcd for $\mathrm{C}_{9} \mathrm{H}_{14} \mathrm{BrO}^{+}\left[\mathrm{M}+\mathrm{H}^{+}\right]$217.0223, found 217.0219.

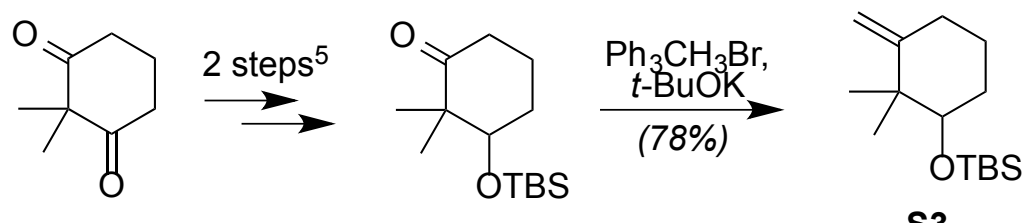

S3

S3. To a flame-dried flask was added $\mathrm{Ph}_{3} \mathrm{PCH}_{3} \mathrm{Br}(3.43 \mathrm{~g}, 9.62 \mathrm{mmol}, 2.0$ equiv) and benzene $(24 \mathrm{~mL})$. Next, solid $t$-BuOK $(0.808 \mathrm{~g}, 7.21 \mathrm{mmol}, 1.5$ equiv) was added at 23 ${ }^{\circ} \mathrm{C}$ and the resultant mixture was then warmed to $80^{\circ} \mathrm{C}$ and stirred at that temperature for $1 \mathrm{~h}$. A solution of 3-tert-butyldimethylsilyloxy-2,2-dimethylcyclohexanone ${ }^{5}$ (1.23 g, $4.81 \mathrm{mmol}$, 1.0 equiv) in benzene $(2 \mathrm{~mL})$ was then added dropwise over the course of $1 \mathrm{~min}$ and the resultant reaction contents were stirred at $80^{\circ} \mathrm{C}$ for an additional $10 \mathrm{~min}$. Upon completion, the reaction contents were cooled, diluted with hexanes $(40 \mathrm{~mL})$, and filtered. The resultant filtrate was concentrated directly and the resultant residue was purified by flash column chromatography (silica gel, hexanes) to afford $\mathbf{S 3}$ (1.02 g, 88\% yield) as a colorless oil. S3: $\mathrm{R}_{f}=0.84$ (silica gel, hexanes/EtOAc, 4/1); IR (film) $v_{\max } 2937,2858,1472,1256,1086,866$, 836, 801, $773 \mathrm{~cm}^{-1} ;{ }^{1} \mathrm{H}$ NMR (500 MHz, $\left.\mathrm{CDCl}_{3}\right) \delta 4.69$ (s, $\left.2 \mathrm{H}\right), 3.27$ (dd, $J=9.6,4.0 \mathrm{~Hz}, 1$ $\mathrm{H}), 2.25-2.15(\mathrm{~m}, 1 \mathrm{H}), 2.10(\mathrm{dt}, J=9.0,4.1 \mathrm{~Hz}, 1 \mathrm{H}), 1.77-1.65(\mathrm{~m}, 2 \mathrm{H}), 1.61-1.51(\mathrm{~m}, 1$ H), 1.33-1.21 (m, 1 H), 1.08 (s, $3 \mathrm{H}), 1.00$ (d, $J=11.4 \mathrm{~Hz}, 3 \mathrm{H}), 0.89$ (s, $9 \mathrm{H}), 0.02$ (s, $6 \mathrm{H})$; ${ }^{13} \mathrm{C}$ NMR $\left(125 \mathrm{MHz}, \mathrm{CDCl}_{3}\right) \delta 155.5,107.1,78.0,42.6,32.3,31.1,25.9,25.2,24.3,20.8$, 4.1, -4.9; HRMS (Mixed+) calcd for $\mathrm{C}_{15} \mathrm{H}_{31} \mathrm{OSi}^{+}\left[\mathrm{M}+\mathrm{H}^{+}\right]$255.2139, found 255.2139. 


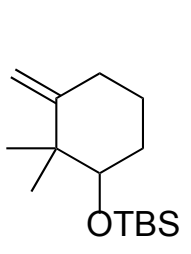

\$3

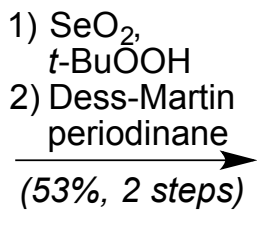

$t$-BuOOOH
2) $\begin{gathered}\text { Dess-Martin } \\ \text { periodinane }\end{gathered}$
$\underset{(53 \%, 2 \text { steps })}{(53}$

34-OTBS<smiles>[R5]OC1CCC(=O)C(=C)C1(C)C</smiles>

Enone 34-OTBS. To a solution of compound S3 (0.112 g, $0.440 \mathrm{mmol}, 1.0$ equiv) in $\mathrm{CHCl}_{3}(6 \mathrm{~mL})$ at $23{ }^{\circ} \mathrm{C}$ was added solid $\mathrm{SeO}_{2}(48.8 \mathrm{mg}, 0.440 \mathrm{mmol}, 1.0$ equiv) followed by $t$-BuOOH $(0.24 \mathrm{~mL}, 5.5 \mathrm{M}$ in nonane, $1.32 \mathrm{mmol}, 3.0$ equiv). The resultant mixture was then stirred at $23{ }^{\circ} \mathrm{C}$ for $11 \mathrm{~h}$. Upon completion, the reaction contents were concentrated directly under reduced pressure and the resultant residue was purified by flash column chromatography (silica gel, hexanes/EtOAc, 10/1) to give the desired allylic alcohol $(97.0 \mathrm{mg}$, $82 \%$ yield $)$ as a colorless oil $\left(\mathrm{R}_{f}=0.24\right.$, silica gel, hexanes/EtOAc, $\left.4 / 1\right)$. Next, the newly prepared allylic alcohol $\left(97.0 \mathrm{mg}, 0.359 \mathrm{mmol}, 1.0\right.$ equiv) was dissolved in $\mathrm{CH}_{2} \mathrm{Cl}_{2}(4 \mathrm{~mL})$ and then $\mathrm{NaHCO}_{3}(90.4 \mathrm{mg}, 1.08 \mathrm{mmol}, 3.0$ equiv) and Dess-Martin periodinane $(0.228 \mathrm{~g}$, $0.538 \mathrm{mmol}, 1.5$ equiv) were added sequentially at $23{ }^{\circ} \mathrm{C}$. The resultant mixture was stirred at $23{ }^{\circ} \mathrm{C}$ for $2 \mathrm{~h}$. Upon completion, the reaction contents were quenched with $10 \%$ aqueous $\mathrm{Na}_{2} \mathrm{~S}_{2} \mathrm{O}_{3}(6 \mathrm{~mL})$, poured into a separatory funnel, and the layers were separated. The aqueous layer was extracted with $\mathrm{CH}_{2} \mathrm{Cl}_{2}(3 \times 3 \mathrm{~mL})$ and the combined organic layers were washed with brine $(5 \mathrm{~mL})$, dried $\left(\mathrm{MgSO}_{4}\right)$, filtered, and concentrated. The resultant residue was purified by flash column chromatography (silica gel, hexanes/EtOAc, 25/1) to afford 34-OTBS (62.5 mg, $65 \%$ yield, $53 \%$ yield over 2 steps) as a colorless oil. 34-OTBS: $\mathrm{R}_{f}=$ 0.57 (silica gel, hexanes/EtOAc, 4/1); IR (film) $v_{\max }$ 2970, 1696, 1615, 1407, 1228, 1209, 1179, 1110, 946, $879 \mathrm{~cm}^{-1} ;{ }^{1} \mathrm{H}$ NMR (500 MHz, $\left.\mathrm{CDCl}_{3}\right) \delta 5.74(\mathrm{~s}, 1 \mathrm{H}), 5.17(\mathrm{~s}, 1 \mathrm{H}), 3.65$ $(\mathrm{dd}, J=6.3,2.7 \mathrm{~Hz}, 1 \mathrm{H}), 2.64(\mathrm{ddd}, J=16.4,9.1,7.0 \mathrm{~Hz}, 1 \mathrm{H}), 2.35(\mathrm{dt}, J=16.9,6.1 \mathrm{~Hz}, 1$ H), 2.13-2.02 (m, 1 H), 1.88 (td, $J=13.0,6.3 \mathrm{~Hz}, 1 \mathrm{H}), 1.10$ (s, $3 \mathrm{H}), 1.05$ (s, $3 \mathrm{H}), 0.87$ (s, 9 $\mathrm{H}), 0.06(\mathrm{~s}, 6 \mathrm{H}) ;{ }^{13} \mathrm{C} \mathrm{NMR}\left(125 \mathrm{MHz}, \mathrm{CDCl}_{3}\right) \delta 202.9,153.7,118.0,75.1,43.1,35.7,27.5$, 26.8, 25.7, 23.6, -4.3, -5.0; HRMS (Mixed+) calcd for $\mathrm{C}_{15} \mathrm{H}_{29} \mathrm{O}_{2} \mathrm{Si}^{+}\left[\mathrm{M}+\mathrm{H}^{+}\right]$269.1931, found 269.1928 .

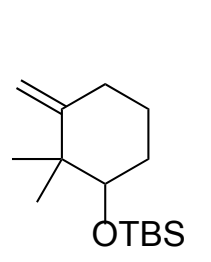

S3

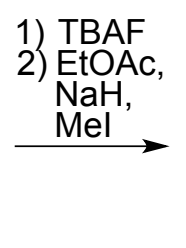

S4

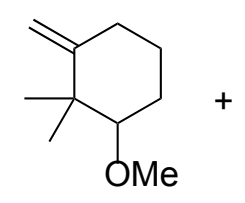<smiles>C=C1CCCC(OC(C)=O)C1(C)C</smiles>

S5
1) $\mathrm{SeO}_{2}$, $t$-BuÖOH

2) Dess-Martin \begin{tabular}{c} 
periodinane \\
\hline $\begin{array}{c}3 \%+6 \% \\
4 \text { steps })\end{array}$
\end{tabular}

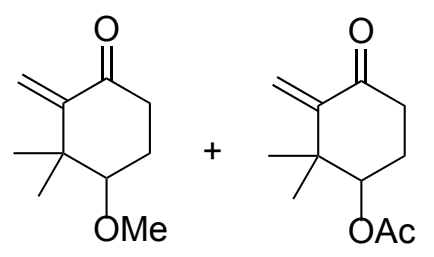

34-OMe

34-OAc

Enone 34-OMe and Enone 34-OAc. Compound S2 (0.346 g, $1.36 \mathrm{mmol}, 1.0$ equiv) was dissolved in THF $(6 \mathrm{~mL})$ and then TBAF (1.0 M in THF, $2.72 \mathrm{~mL}, 2.72 \mathrm{mmol}, 2.0$ equiv) was added at $23{ }^{\circ} \mathrm{C}$. The resultant solution was then warmed to $45{ }^{\circ} \mathrm{C}$ and stirred at this temperature for $12 \mathrm{~h}$. Upon completion, the reaction contents were cooled, quenched by the addition of a half-saturated aqueous solution of $\mathrm{NH}_{4} \mathrm{Cl}(10 \mathrm{~mL})$ and poured into a separatory funnel. After separating the layers, the aqueous layer was extracted with EtOAc $(3 \times 10 \mathrm{~mL})$, and the combined organic layers were washed with brine $(15 \mathrm{~mL})$, dried, filtered, and 
concentrated to give a mixture of the desired crude alcohol $\left(\mathrm{R}_{f}=0.29\right.$, silica gel, hexanes/EtOAc, 4/1) along with some residual EtOAc. Next, the so-obtained mixture of the crude alcohol (1.36 mmol assumed, 1.0 equiv) and residual EtOAc was dissolved in THF (2 $\mathrm{mL})$ and $\mathrm{MeI}(0.25 \mathrm{~mL}, 3.92 \mathrm{mmol}, 3.0$ equiv) and $\mathrm{NaH}(60 \%$ dispersion in mineral oil, 82.0 $\mathrm{mg}, 2.04 \mathrm{mmol}, 1.5$ equiv) were added sequentially at $23{ }^{\circ} \mathrm{C}$. The resultant mixture was then warmed to $45{ }^{\circ} \mathrm{C}$ and stirred at that temperature for $2 \mathrm{~h}$. Upon completion, the reaction contents were quenched by the addition of a half-saturated aqueous solution of $\mathrm{NH}_{4} \mathrm{Cl}(10$ $\mathrm{mL}$ ), the contents were poured into a separatory funnel, and the layers were separated. The aqueous layer was extracted with EtOAc $(3 \times 10 \mathrm{~mL})$, and the combined organic layers were washed with brine $(15 \mathrm{~mL})$, dried, filtered, concentrated. The resultant residue was purified by flash column chromatography (silica gel, hexanes/EtOAc, 6/1) to give an inseparable mixture of methyl ether $\mathbf{S 4}$ and acetate $\mathbf{S 5}$ (104 mg, $\mathrm{R}_{f}=0.34$, silica gel, hexane/EtOAc, 4/1). Carrying a portion of this mixture forward $(60 \mathrm{mg}, 0.389 \mathrm{mmol}$ assumed, 1.0 equiv), it was dissolved in $\mathrm{CHCl}_{3}(5 \mathrm{~mL})$ and then solid $\mathrm{SeO}_{2}(43 \mathrm{mg}, 0.389 \mathrm{mmol}, 1.0$ equiv) and $t$ - $\mathrm{BuOOH}(5.5 \mathrm{M}$ in nonane, $0.21 \mathrm{~mL}, 1.17 \mathrm{mmol}, 3.0$ equiv) were added sequentially at 23 ${ }^{\circ} \mathrm{C}$. The resultant mixture was stirred at $23{ }^{\circ} \mathrm{C}$ for $12 \mathrm{~h}$ before the solvent was concentrated directly. The resultant residue was then purified by flash column chromatography (silica gel, hexanes/EtOAc, 3/1) to give an inseparable mixture of the desired allylic alcohols (24.0 mg). Finally, the inseparable mixture of allylic alcohols $(24.0 \mathrm{mg}, 0.140 \mathrm{mmol}$ assumed, 1.0 equiv) was dissolved in $\mathrm{CH}_{2} \mathrm{Cl}_{2}(3 \mathrm{~mL})$ and solid $\mathrm{NaHCO}_{3}(36.0 \mathrm{mg}, 0.420 \mathrm{mmol}, 3.0$ equiv) and Dess-Martin periodinane $\left(89.0 \mathrm{mg}, 0.210 \mathrm{mmol}, 1.5\right.$ equiv) were sequentially added at $23{ }^{\circ} \mathrm{C}$. The resultant reaction mixture was stirred at $23{ }^{\circ} \mathrm{C}$ for $2 \mathrm{~h}$. Upon completion, the reaction contents were quenched by the addition of aqueous $\mathrm{Na}_{2} \mathrm{~S}_{2} \mathrm{O}_{3}(10 \%, 3 \mathrm{~mL})$, poured into a separatory funnel, and the layers were separated. The aqueous layer was extracted with $\mathrm{CH}_{2} \mathrm{Cl}_{2}(3 \times 2 \mathrm{~mL})$, and the combined organic layers were washed by brine $(5 \mathrm{~mL})$, dried $\left(\mathrm{MgSO}_{4}\right)$, filtered, and concentrated. The resultant residue was purified by preparative thin-layer chromatography (silica gel, hexanes/EtOAc, 3/2) to afford 34-OMe $(3.5 \mathrm{mg}, 3 \%$ yield over 4 steps) as a colorless oil and 34-OAc (7.0 mg, 6\% yield over 4 steps) as a colorless oil. 34-OMe: $\mathrm{R}_{f}=0.38$ (silica gel, hexanes/EtOAc, 4/1); IR (film) $v_{\max } 2970$, 1696, 1616, 1457, 1237, 1098, $937 \mathrm{~cm}^{-1} ;{ }^{1} \mathrm{H}$ NMR (500 MHz, $\left.\mathrm{CDCl}_{3}\right) \delta 5.79$ (s, $\left.1 \mathrm{H}\right), 5.23$ (s, $1 \mathrm{H}), 3.40(\mathrm{~s}, 3 \mathrm{H}), 3.16(\mathrm{t}, J=4.1 \mathrm{~Hz}, 1 \mathrm{H}), 2.64-2.54(\mathrm{~m}, 1 \mathrm{H}), 2.38(\mathrm{dt}, J=16.9,5.6 \mathrm{~Hz}, 1$ $\mathrm{H}), 2.12-2.05(\mathrm{~m}, 3 \mathrm{H}), 1.19(\mathrm{~s}, 3 \mathrm{H}), 1.10(\mathrm{~s}, 3 \mathrm{H}) ;{ }^{13} \mathrm{C} \mathrm{NMR}\left(125 \mathrm{MHz}, \mathrm{CDCl}_{3}\right) \delta 202.5$, 153.3, 118.2, 83.8, 57.3, 42.4, 35.5, 27.3, 23.5, 21.9; HRMS (ESI+) calcd for $\mathrm{C}_{10} \mathrm{H}_{17} \mathrm{O}_{2}{ }^{+}[\mathrm{M}+$ $\left.\mathrm{H}^{+}\right]$169.1223, found 169.1219 .

34-OAc: $\mathrm{R}_{f}=0.35$ (silica gel, hexanes/EtOAc, 4/1); IR (film) $v_{\max } 2970,1739,1697$, 1374, 1239, 1038, 974, 937, $857 \mathrm{~cm}^{-1} ;{ }^{1} \mathrm{H}$ NMR (500 MHz, CDCl$) \delta 5.84(\mathrm{~s}, 1 \mathrm{H}), 5.27$ (s, 1 H), $4.94(\mathrm{dd}, J=6.2,3.1 \mathrm{~Hz}, 1 \mathrm{H}), 2.58(\mathrm{ddd}, J=16.5,9.2,7.1 \mathrm{~Hz}, 1 \mathrm{H}), 2.47(\mathrm{dt}, J=17.2$, $6.1 \mathrm{~Hz}, 1 \mathrm{H}), 2.22-2.14(\mathrm{~m}, 1 \mathrm{H}), 2.08(\mathrm{~s}, 3 \mathrm{H}), 2.07-2.01(\mathrm{~m}, 1 \mathrm{H}), 1.15(\mathrm{~s}, 3 \mathrm{H}), 1.13$ (s, 3 $\mathrm{H}) ;{ }^{13} \mathrm{C}$ NMR $\left(125 \mathrm{MHz}, \mathrm{CDCl}_{3}\right) \delta 201.3,170.4,152.4,118.9,76.0,41.3,35.7,26.8,24.1$, 23.4, 21.0; HRMS (APCI+) calcd for $\mathrm{C}_{11} \mathrm{H}_{17} \mathrm{O}_{3}{ }^{+}\left[\mathrm{M}+\mathrm{H}^{+}\right]$197.1172, found 197.1173. 
General method for the Diels-Alder Cycloaddition. Method A: To a flame-dried flask was charged with a $0.1 \mathrm{M}$ solution of enone 29, 34-OTBS, 34-OMe, or 34-OAc (1.0 equiv) in $\mathrm{CH}_{2} \mathrm{Cl}_{2}(0.5 \mathrm{M})$. After the solution was cooled to $-78^{\circ} \mathrm{C}$, isoprene (4.0 equiv) was added, followed by the dropwise addition of the Lewis acid promoter (1.2 equiv) over the course of $10 \mathrm{~min}$. The resultant reaction mixture was stirred at $-78{ }^{\circ} \mathrm{C}$ for $4 \mathrm{~h}$, at which time it was allowed to warm to $-50{ }^{\circ} \mathrm{C}$ slowly over the course of $30 \mathrm{~min}$. The reaction contents were then either kept at $-50{ }^{\circ} \mathrm{C}$ for $1 \mathrm{~h}$. Upon completion, the reaction contents were quenched by the slow addition of aqueous $\mathrm{HCl}(2 \mathrm{M}$, equal in volume to that of the original reaction solvent), poured into a separatory funnel, and the layers were separated. The aqueous layer was then extracted with $\mathrm{CH}_{2} \mathrm{Cl}_{2}(3 \times 1 / 3$ of volume of reaction). The combined organic layers were washed with brine (equal to volume of reaction), dried $\left(\mathrm{MgSO}_{4}\right)$, filtered, and concentrated. The resultant residue was purified by flash column chromatography (silica gel) to afford the desired spirocycle products.

Method B: To a flame-dried flask was charged with a $0.1 \mathrm{M}$ solution of enone 29, 34-OTBS, 34-OMe, or 34-OAc (1.0 equiv) in $\mathrm{CH}_{2} \mathrm{Cl}_{2}(0.5 \mathrm{M})$. After the solution was cooled to $-30{ }^{\circ} \mathrm{C}$, isoprene ( 4.0 equiv) was added, followed by the dropwise addition of the Lewis acid promoter (1.2 equiv) over the course of $10 \mathrm{~min}$. The resultant reaction mixture was stirred at $-30{ }^{\circ} \mathrm{C}$ for $1 \mathrm{~h}$, at which time it was allowed to warm to $0{ }^{\circ} \mathrm{C}$ slowly over the course of $15 \mathrm{~min}$. The reaction contents were then either kept at $0{ }^{\circ} \mathrm{C}$ for $10 \mathrm{~min}$. Upon completion, the reaction contents were quenched by the slow addition of aqueous $\mathrm{HCl}(2 \mathrm{M}$, equal in volume to that of the original reaction solvent), poured into a separatory funnel, and the layers were separated. The aqueous layer was then extracted with $\mathrm{CH}_{2} \mathrm{Cl}_{2}(3 \times 1 / 3$ of volume of reaction). The combined organic layers were washed with brine (equal to volume of reaction), dried $\left(\mathrm{MgSO}_{4}\right)$, filtered, and concentrated. The resultant residue was purified by flash column chromatography (silica gel) to afford the desired spirocycle products.

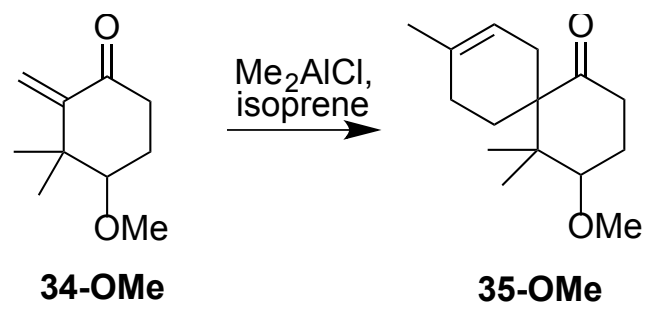

Spirocyclic ketone 35-OMe. Enone 34-OMe (3.2 mg, $0.019 \mathrm{mmol})$ afforded minor diastereomer 35-OMe (minor) $(1.3 \mathrm{mg}, 29 \%$ yield) as a colorless oil and major diastereomer 35-OMe (major) $(1.6 \mathrm{mg}, 36 \%$ yield) as a colorless oil using Method A. Minor diastereomer 35-OMe (minor): $\mathrm{R}_{f}=0.50$ (silica gel, hexanes/EtOAc, 4/1); IR (film) $v_{\max }$ 2967, 2831, 1710, 1451, 1367, 1231, 1100, $962 \mathrm{~cm}^{-1} ;{ }^{1} \mathrm{H}$ NMR (500 MHz, $\left.\mathrm{CDCl}_{3}\right) \delta 5.33(\mathrm{~s}$, $1 \mathrm{H}), 3.38(\mathrm{~s}, 3 \mathrm{H}), 3.05(\mathrm{t}, J=3.7 \mathrm{~Hz}, 1 \mathrm{H}), 2.82(\mathrm{td}, J=12.4,6.1 \mathrm{~Hz}, 1 \mathrm{H}), 2.63-2.55(\mathrm{~m}, 1$ $\mathrm{H}), 2.24(\mathrm{~d}, J=17.2 \mathrm{~Hz}, 1 \mathrm{H}), 2.17(\mathrm{dt}, J=12.6,4.9 \mathrm{~Hz}, 1 \mathrm{H}), 2.10-2.03(\mathrm{~m}, 1 \mathrm{H}), 2.01-1.93$ $(\mathrm{m}, 1 \mathrm{H}), 1.89(\mathrm{~d}, J=17.0 \mathrm{~Hz}, 1 \mathrm{H}), 1.82(\mathrm{dd}, J=17.4,5.1 \mathrm{~Hz}, 1 \mathrm{H}), 1.71(\mathrm{t}, J=14.5 \mathrm{~Hz}, 1$ $\mathrm{H}), 1.56(\mathrm{~s}, 3 \mathrm{H}), 1.03(\mathrm{~s}, 3 \mathrm{H}), 0.80(\mathrm{~s}, 3 \mathrm{H}) ;{ }^{13} \mathrm{C} \mathrm{NMR}\left(125 \mathrm{MHz}, \mathrm{CDCl}_{3}\right) \delta 214.9,132.8$, 119.5, 85.5, 57.9, 54.8, 45.5, 33.1, 28.1, 27.6, 27.2, 25.8, 23.8, 23.2, 19.4; HRMS (Mixed+) calcd for $\mathrm{C}_{15} \mathrm{H}_{25} \mathrm{O}_{2}^{+}\left[\mathrm{M}+\mathrm{H}^{+}\right]$237.1849, found 237.1851. 
Major diastereomer 35-OMe (major): $\mathrm{R}_{f}=0.45$ (silica gel, hexanes/EtOAc, 4/1); IR (film) $v_{\max } 2967,1710,1456,1436,1367,1231,1100 \mathrm{~cm}^{-1} ;{ }^{1} \mathrm{H}$ NMR $\left(500 \mathrm{MHz}, \mathrm{CDCl}_{3}\right) \delta$ 5.42-5.36 (m, $1 \mathrm{H}), 3.56(\mathrm{dd}, J=11.5,4.6 \mathrm{~Hz}, 1 \mathrm{H}), 3.40(\mathrm{~s}, 3 \mathrm{H}), 2.69(\mathrm{td}, J=13.9,6.7 \mathrm{~Hz}$, $1 \mathrm{H}), 2.34-2.21(\mathrm{~m}, 3 \mathrm{H}), 2.16-2.09(\mathrm{~m}, 1 \mathrm{H}), 1.89-1.80(\mathrm{~m}, 2 \mathrm{H}), 1.75(\mathrm{td}, J=13.1,4.8 \mathrm{~Hz}, 1$ $\mathrm{H}), 1.68-1.60(\mathrm{~m}, 2 \mathrm{H}), 1.58(\mathrm{~s}, 3 \mathrm{H}), 1.03(\mathrm{~s}, 3 \mathrm{H}), 0.72(\mathrm{~s}, 3 \mathrm{H}) ;{ }^{13} \mathrm{C}$ NMR $(125 \mathrm{MHz}$, $\left.\mathrm{CDCl}_{3}\right) \delta 213.2,131.3,120.6,81.5,58.0,54.4,44.6,34.8,27.4,27.2,26.5,26.3,23.2,21.0$, 16.4; HRMS (Mixed+) calcd for $\mathrm{C}_{15} \mathrm{H}_{25} \mathrm{O}_{2}^{+}\left[\mathrm{M}+\mathrm{H}^{+}\right] 237.1849$, found 237.1850.

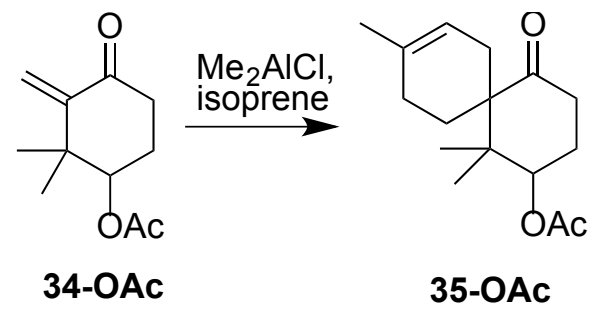

Spirocyclic Ketone 35-OAc. Enone 34-OAc $(7.0 \mathrm{mg}, 0.036 \mathrm{mmol})$ afforded an inseparable mixture of diastereomers of 35-OAc $(6.6 \mathrm{mg}, \mathrm{dr}=1.2 / 1,75 \%$ yield combined $)$ as a colorless oil using Method A. 35-OAc: $\mathrm{R}_{f}=0.41$ ( silica gel, hexanes/EtOAc, 4/1); IR (film) $v_{\max } 2969,1735,1711,1436,1373,1243,1032,973 \mathrm{~cm}^{-1} ;{ }^{1} \mathrm{H}$ NMR $\left(500 \mathrm{MHz}, \mathrm{CDCl}_{3}\right)$ $\delta 5.43-5.36(\mathrm{~m}, 2 \mathrm{H}), 5.33(\mathrm{~d}, J=1.7 \mathrm{~Hz}, 1 \mathrm{H}), 5.01-4.95(\mathrm{~m}, 1 \mathrm{H}), 2.81(\mathrm{td}, J=14.0,6.8 \mathrm{~Hz}$, $1 \mathrm{H}), 2.69$ (ddd, $J=13.0,10.5,6.2 \mathrm{~Hz}, 1 \mathrm{H}), 2.44$ (dd, $J=12.9,2.5 \mathrm{~Hz}, 1 \mathrm{H}), 2.40-2.30$ (m, 3 H), 2.30-2.20 (m, 2 H), $2.13(\mathrm{~s}, 3 \mathrm{H}), 2.17-2.10(\mathrm{~m}, 1 \mathrm{H}), 2.08(\mathrm{~s}, 3 \mathrm{H}), 2.03-1.91(\mathrm{~m}, 3 \mathrm{H})$, 1.91-1.81 (m, $4 \mathrm{H}), 1.76$ (td, $J=13.2,4.8 \mathrm{~Hz}, 2 \mathrm{H}), 1.66-1.60(\mathrm{~m}, 2 \mathrm{H}), 0.95$ (s, $6 \mathrm{H}), 0.86$ (s, $3 \mathrm{H}), 0.81(\mathrm{~s}, 3 \mathrm{H}) ;{ }^{13} \mathrm{C}$ NMR $\left(125 \mathrm{MHz}, \mathrm{CDCl}_{3}\right) \delta 213.4,212.0,170.7,170.4,133.1,131.5$, $120.2,118.8,76.3,73.9,54.6,54.4,44.3,43.2,34.7,33.5,28.1,28.0,27.8,27.3,27.2,27.0$, 26.3, 26.2, 23.1, 22.8, 21.3, 21.2, 20.8, 18.8, 16.8; HRMS (Mixed+) calcd for $\mathrm{C}_{16} \mathrm{H}_{25} \mathrm{O}_{3}{ }^{+}[\mathrm{M}$ $\left.+\mathrm{H}^{+}\right]$265.1798, found 265.1799 .

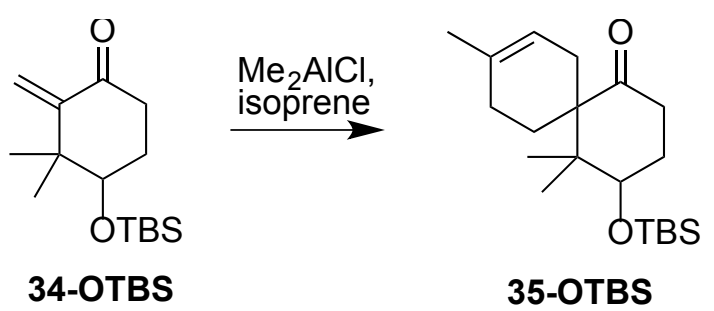

Spirocyclic Ketone 35-OTBS. Enone 34-OTBS (0.198 g, $0.738 \mathrm{mmol})$ afforded an inseparable mixture of diastereomers of 35-OTBS $(0.221 \mathrm{~g}, \mathrm{dr}=1.4 / 1,89 \%$ yield combined $)$ as a colorless oil using Method A; Method B gave 66\% yield with a $\mathrm{dr}=1 / 1$. 35-OTBS: $\mathrm{R}_{f}$ $=0.61$ (silica gel, hexanes/EtOAc, 4/1); IR (film) $v_{\max }$ 2956, 2930, 1710, 1472, 1257, 1089, 881, 836, $775 \mathrm{~cm}^{-1} ;{ }^{1} \mathrm{H}$ NMR $\left(500 \mathrm{MHz}, \mathrm{CDCl}_{3}\right) \delta 5.41(\mathrm{~s}, 1 \mathrm{H}), 5.36(\mathrm{~s}, 1 \mathrm{H}), 4.15(\mathrm{dd}, J=$ $11.2,4.8 \mathrm{~Hz}, 1 \mathrm{H}), 3.63(\mathrm{t}, J=3.7 \mathrm{~Hz}, 1 \mathrm{H}), 2.95(\mathrm{td}, J=12.4,5.9 \mathrm{~Hz}, 1 \mathrm{H}), 2.82-2.70(\mathrm{~m}, 2$ $\mathrm{H})$, 2.37-2.13 (m, $7 \mathrm{H}), 2.13-2.04(\mathrm{~m}, 2 \mathrm{H}), 2.03-1.95(\mathrm{~m}, 1 \mathrm{H}), 1.94-1.83(\mathrm{~m}, 7 \mathrm{H})$, 1.81-1.71 (m, 4 H), 1.70-1.62 (m, 3 H), 1.60 (s, 7 H), 1.01 (s, 4 H), 0.99 (s, 3 H), 0.96 (s, 13 $\mathrm{H}), 0.92(\mathrm{~s}, 9 \mathrm{H}), 0.79(\mathrm{~s}, 4 \mathrm{H}), 0.74(\mathrm{~s}, 3 \mathrm{H}), 0.13-0.09(\mathrm{~m}, 15 \mathrm{H}) ;{ }^{13} \mathrm{C}$ NMR $(125 \mathrm{MHz}$, $\left.\mathrm{CDCl}_{3}\right) \delta 215.0,213.2,132.6,131.3,120.6,119.5,76.4,72.5,54.8,54.4,45.7,44.9,35.0$, 
33.0, 31.4, 31.4, 28.1, 27.6, 27.4, 27.1, 26.7, 25.8, 25.8, 23.6, 23.2, 21.7, 20.0, 18.0, 16.0, -4.0, -4.4; HRMS (Mixed+) calcd for $\mathrm{C}_{20} \mathrm{H}_{37} \mathrm{O}_{2} \mathrm{Si}^{+}\left[\mathrm{M}+\mathrm{H}^{+}\right]$337.2557, found 337.2553.<smiles>C=C1C(=O)CCC(Br)C1(C)C</smiles>

29

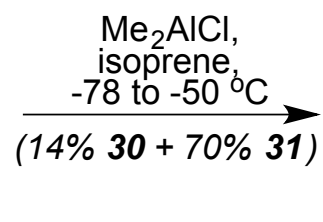

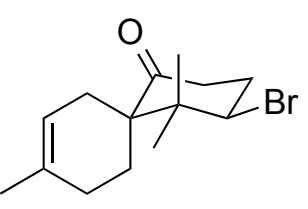

30<smiles>CC1=CCC(C(=O)C2(C)CCC2Br)CC1</smiles>

31

Spirocyclic Bromo Ketones 30 and 31. Enone 29 ( $0.223 \mathrm{~g}, 1.03 \mathrm{mmol}, 1.0$ equiv) afforded 31 (0.206 g, 70\% yield) as a white solid and $\mathbf{3 0}(42.0 \mathrm{mg}, 14 \%$ yield $)$ as a white solid using Method A; Method B gave 60\% yield of $\mathbf{3 1}$ only. Recrystallization of these two materials respectively from hexanes $/ \mathrm{CH}_{2} \mathrm{Cl}_{2}$ afforded crystals of suitable quality for X-ray diffraction, with the resultant crystal structure shown below in Figures S2 and S3. 31: $\mathrm{R}_{f}=$ 0.58 (silica gel, hexanes/EtOAc, 4/1); m.p. $=90-92{ }^{\circ} \mathrm{C}$; IR (film) $v_{\max } 2973,1708,1445$, 1394, 1374, 1154, 963, 860, $780 \mathrm{~cm}^{-1} ;{ }^{1} \mathrm{H}$ NMR $\left(500 \mathrm{MHz}, \mathrm{CDCl}_{3}\right) \delta 5.28(\mathrm{t}, J=10.3 \mathrm{~Hz}, 1$ H), $4.66(\mathrm{dd}, J=11.2,4.7 \mathrm{~Hz}, 1 \mathrm{H}), 2.81-2.70(\mathrm{~m}, 1 \mathrm{H}), 2.54-2.39$ (m, $2 \mathrm{H}), 2.36-2.20$ (m, 3 H), 2.29-2.27 (m, $3 \mathrm{H}), 2.24-2.18(\mathrm{~m}, 1 \mathrm{H}), 1.89(\mathrm{dd}, J=16.6,6.0 \mathrm{~Hz}, 1 \mathrm{H}), 1.56(\mathrm{~s}, 3 \mathrm{H})$, 1.54-1.48 (m, $1 \mathrm{H}), 1.10(\mathrm{~s}, 3 \mathrm{H}), 0.98(\mathrm{~s}, 3 \mathrm{H}) ;{ }^{13} \mathrm{C} \mathrm{NMR}\left(125 \mathrm{MHz}, \mathrm{CDCl}_{3}\right) \delta 212.0,135.7$, 116.6, 61.1, 55.2, 45.6, 37.4, 34.0, 29.2, 28.5, 24.7, 24.2, 23.0, 18.5; HRMS (Mixed+) calcd for $\mathrm{C}_{14} \mathrm{H}_{21} \mathrm{BrO}^{+}\left[\mathrm{M}+\mathrm{H}^{+}\right]$285.0849, found 285.0844.

Figure S2. ORTEP representation of $\mathbf{3 1 .}$

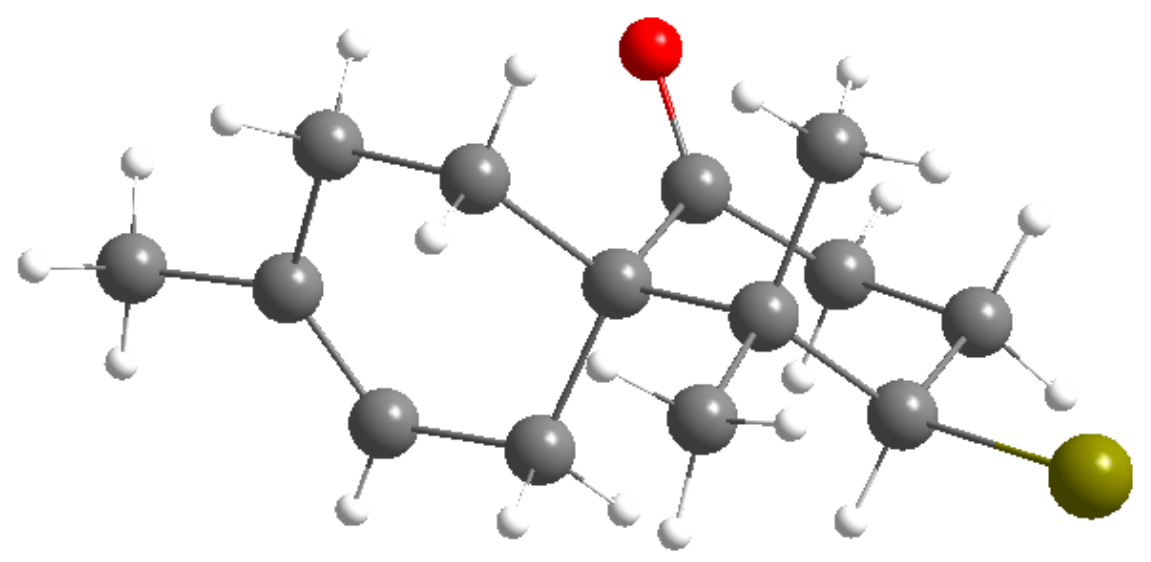

30: $\mathrm{R}_{f}=0.54$ (silica gel, hexanes/EtOAc, 4/1); m.p. $=102-103{ }^{\circ} \mathrm{C}$; IR (film) $v_{\max }$ 2949, 1704, 1653, 1559, 1456, $668 \mathrm{~cm}^{-1} ;{ }^{1} \mathrm{H}$ NMR (500 MHz, $\left.\mathrm{CDCl}_{3}\right) \delta 5.37(\mathrm{~s}, 1 \mathrm{H}), 4.80$ $(\mathrm{dd}, J=12.6,4.7 \mathrm{~Hz}, 1 \mathrm{H}), 2.85-2.75(\mathrm{~m}, 1 \mathrm{H}), 2.49(\mathrm{ddd}, J=11.4,7.3,3.4 \mathrm{~Hz}, 1 \mathrm{H}), 2.37$ (d, $J=15.9 \mathrm{~Hz}, 1 \mathrm{H}), 2.31-2.22(\mathrm{~m}, 2 \mathrm{H}), 2.19-2.13(\mathrm{~m}, 1 \mathrm{H}), 1.90(\mathrm{dd}, J=29.4,11.8 \mathrm{~Hz}, 2 \mathrm{H})$, 1.85-1.77 (m, $1 \mathrm{H}), 1.66-1.60(\mathrm{~m}, 1 \mathrm{H}), 1.59$ (s, $3 \mathrm{H}), 1.16(\mathrm{~s}, 3 \mathrm{H}), 0.90(\mathrm{~s}, 3 \mathrm{H}) ;{ }^{13} \mathrm{C} \mathrm{NMR}$ $\left(125 \mathrm{MHz}, \mathrm{CDCl}_{3}\right) \delta 210.7,131.2,120.5,61.1,56.0,45.0,37.7,33.9,27.4,27.2,27.0,24.3$, 23.1, 17.6; HRMS (Mixed+) calcd for $\mathrm{C}_{14} \mathrm{H}_{21} \mathrm{BrO}^{+}\left[\mathrm{M}+\mathrm{H}^{+}\right]$285.0849, found 285.0825. 
Figure S3. ORTEP representation of $\mathbf{3 0 .}$

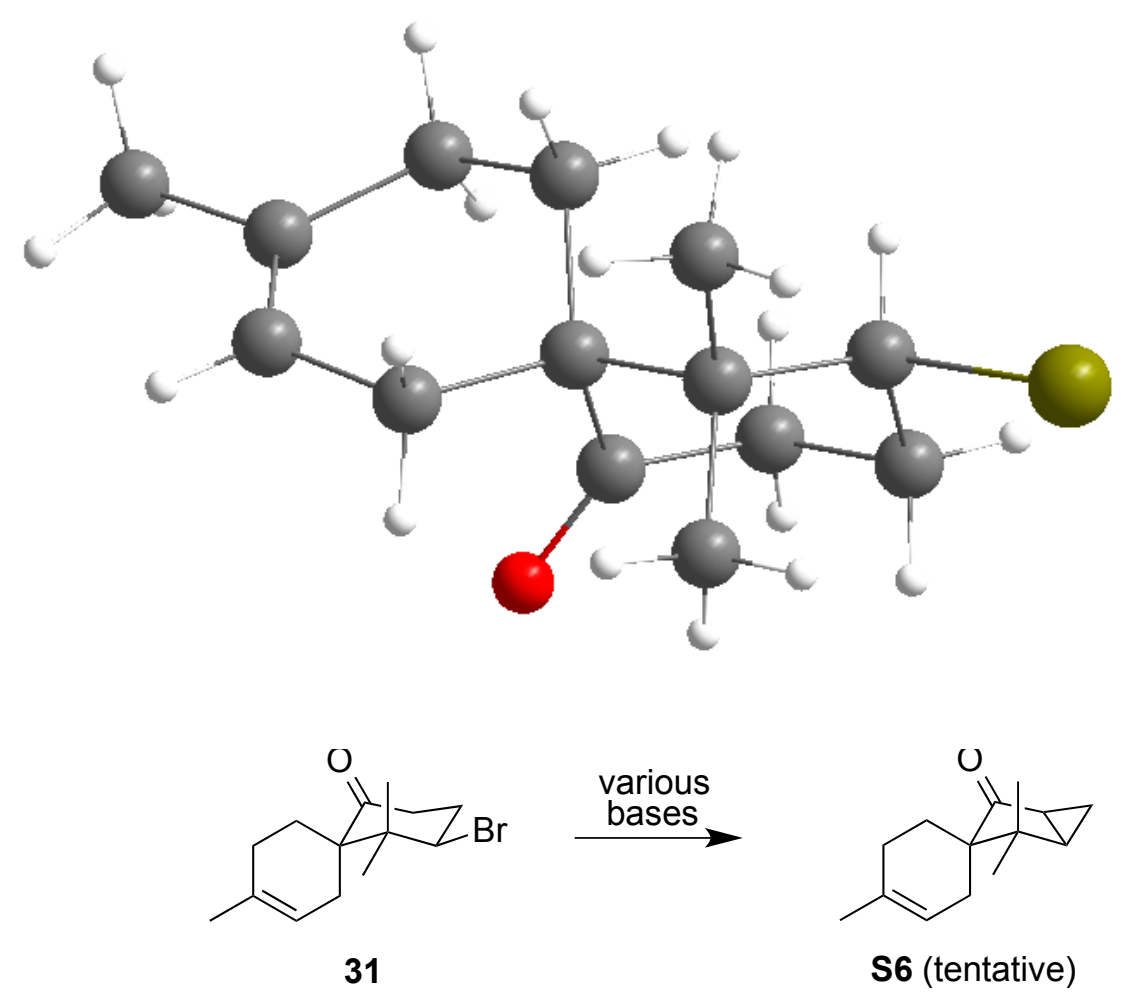

Cyclopropane S6. Exposure of 31 to KHMDS, MeLi, TMSCH${ }_{2} \mathrm{Li}, \mathrm{PPh}_{3} \mathrm{CH}_{2}$ (formed by treatment of $\mathrm{PPh}_{3} \mathrm{CH}_{3} \mathrm{Br}$ with $t$-BuOK or $n \mathrm{BuLi}$ ) led to rapid formation of $\mathbf{S 6}$ (structure tentatively assigned) quantitatively as a colorless oil. S6: $\mathrm{R}_{f}=0.48$ (silica gel, hexanes/EtOAc, 4/1); IR (film) $v_{\max }$ 2964, 2913, 1716, 1463, 1367, 1306, 1242, 1182, 1155 , 965, 952, 926, $804 \mathrm{~cm}^{-1}$; ${ }^{1} \mathrm{H}$ NMR (500 MHz, $\left.\mathrm{CDCl}_{3}\right) \delta 5.38(\mathrm{~s}, 1 \mathrm{H}), 1.96-1.80(\mathrm{~m}, 5 \mathrm{H})$, 1.76-1.66 (m, $2 \mathrm{H}), 1.62(\mathrm{~s}, 3 \mathrm{H}), 1.56-1.48(\mathrm{~m}, 1 \mathrm{H}), 1.37$ (td, $J=4.9,3.1 \mathrm{~Hz}, 1 \mathrm{H}), 1.07$ (s, $6 \mathrm{H}), 1.01(\mathrm{td}, J=8.6,5.5 \mathrm{~Hz}, 1 \mathrm{H}) ;{ }^{13} \mathrm{C} \mathrm{NMR}\left(125 \mathrm{MHz}, \mathrm{CDCl}_{3}\right) \delta 216.8,132.8,119.6,49.3$, 40.2 , 33.8, 31.0, 29.9, 28.2, 28.1, 27.9, 23.0, 22.6, 14.2; HRMS (Mixed+) calcd for $\mathrm{C}_{14} \mathrm{H}_{20} \mathrm{O}^{+}$ $\left[\mathrm{M}+\mathrm{H}^{+}\right]$205.1587, found 205.1590 .

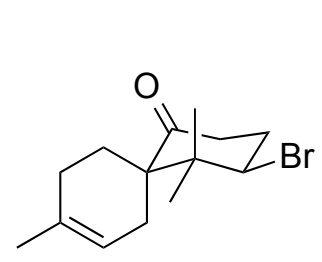

31

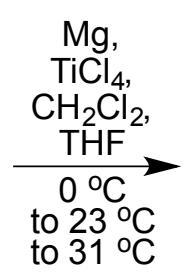

(48\%)<smiles>C=C1CC2(CC1Br)C(Br)CC21CC=C(C)CC1</smiles>

32

Bromo Spirocyclic Alkene 32. To a flame-dried vial was added $\mathrm{Mg}$ powder (31.0 $\mathrm{mg}, 1.26 \mathrm{mmol}, 10$ equiv) and $\mathrm{CH}_{2} \mathrm{Cl}_{2}(0.2 \mathrm{~mL})$. The resultant suspension was cooled to 0 ${ }^{\circ} \mathrm{C}$ and $\mathrm{TiCl}_{4}$ (1.0 M in $\mathrm{CH}_{2} \mathrm{Cl}_{2}, 0.63 \mathrm{~mL}, 0.63 \mathrm{mmol}, 5.0$ equiv) was added dropwise over the course of $1 \mathrm{~min}$ at $0{ }^{\circ} \mathrm{C}$. After stirring at $0{ }^{\circ} \mathrm{C}$ for $5 \mathrm{~min}$, a solution of $\mathbf{3 1}$ (36.0 mg, 0.126 mmol, 1.0 equiv) in THF/ $\mathrm{CH}_{2} \mathrm{Cl}_{2}(0.3 \mathrm{~mL} / 0.8 \mathrm{~mL})$ was added dropwise over the course of 5 min, resulting in a color change from light yellow to green and then to black to be observed. The resulting mixture was then vigorously stirred at $0{ }^{\circ} \mathrm{C}$ for $15 \mathrm{~min}$, at $23{ }^{\circ} \mathrm{C}$ for $20 \mathrm{~min}$, and 
finally at $31{ }^{\circ} \mathrm{C}$ for $5 \mathrm{~h}$. Upon completion, the resultant viscous mixture was quenched by being poured into aqueous $\mathrm{K}_{2} \mathrm{CO}_{3}(5 \%, 5 \mathrm{~mL})$, followed by the addition of saturated aqueous Rochelle's salt $(20 \mathrm{~mL})$. The resultant black mixture was stirred vigorously at $23{ }^{\circ} \mathrm{C}$ for 16 $\mathrm{h}$ until phase separation occurred, was then poured into a separatory funnel, and the layers were separated. The aqueous layer was then extracted with $\mathrm{CH}_{2} \mathrm{Cl}_{2}(3 \times 2 \mathrm{~mL})$, and the combined organic layers were washed with brine $(4 \mathrm{~mL})$, dried $\left(\mathrm{MgSO}_{4}\right)$, filtered, and concentrated. The resultant residue was purified by flash column chromatography (silica gel, hexanes) to afford $32\left(17.0 \mathrm{mg}, 48 \%\right.$ yield) as a colorless oil. $32: \mathrm{R}_{f}=0.80$ (silica gel, hexanes/EtOAc, 4/1); IR (film) $v_{\max } 2958,1456,1389,1368,1213,1156,1070,896 \mathrm{~cm}^{-1} ;{ }^{1} \mathrm{H}$ $\operatorname{NMR}\left(500 \mathrm{MHz}, \mathrm{CDCl}_{3}\right) \delta 5.27(\mathrm{~s}, 1 \mathrm{H}), 4.97(\mathrm{~s}, 1 \mathrm{H}), 4.75(\mathrm{~d}, J=1.1 \mathrm{~Hz}, 1 \mathrm{H}), 4.46(\mathrm{dd}, J=$ 8.4, 4.1 Hz, $1 \mathrm{H}), 2.45-2.38(\mathrm{~m}, 1 \mathrm{H}), 2.35-2.30$ (m, $1 \mathrm{H}), 2.29-2.23$ (m, $2 \mathrm{H}), 2.18-2.09$ (m, $3 \mathrm{H}), 1.96-1.89$ (m, $1 \mathrm{H}), 1.85$ (dd, $J=17.6,5.7 \mathrm{~Hz}, 2 \mathrm{H}), 1.68$ (ddd, $J=13.2,11.6,6.3 \mathrm{~Hz}, 1$ $\mathrm{H}), 1.58(\mathrm{~s}, 3 \mathrm{H}), 1.07(\mathrm{~s}, 3 \mathrm{H}), 1.04(\mathrm{~s}, 3 \mathrm{H}) ;{ }^{13} \mathrm{C} \mathrm{NMR}\left(125 \mathrm{MHz}, \mathrm{CDCl}_{3}\right) \delta 147.6,133.2$, 118.7, 111.1, 66.1, 46.1, 43.1, 35.5, 31.5, 29.2, 28.2, 26.2, 24.4, 23.1, 21.0; HRMS (APCI+) calcd for $\mathrm{C}_{15} \mathrm{H}_{23} \mathrm{Br}^{+}\left[\mathrm{M}^{+}\right] 282.0978$, found 282.0982.

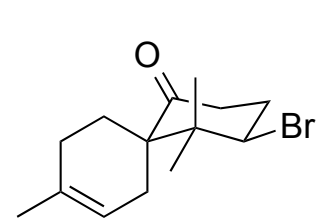

30

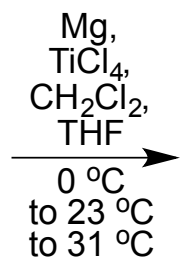

(53\%)

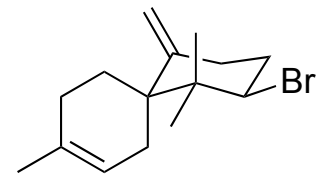

1: $( \pm)-10$-bromo- $\beta$-chamigrene

1: ( \pm )-10- $\boldsymbol{\beta}$-bromo-chamigrene. To a flame-dried vial was added $\mathrm{Mg}$ powder $(25.6$ $\mathrm{mg}, 1.06 \mathrm{mmol}, 10$ equiv) and $\mathrm{CH}_{2} \mathrm{Cl}_{2}(0.2 \mathrm{~mL})$. The resultant suspension was cooled to 0 ${ }^{\circ} \mathrm{C}$ and $\mathrm{TiCl}_{4}$ (1.0 $\mathrm{M}$ in $\mathrm{CH}_{2} \mathrm{Cl}_{2}, 0.53 \mathrm{~mL}, 0.53 \mathrm{mmol}, 5.0$ equiv) was added dropwise over the course of $1 \mathrm{~min}$ at $0{ }^{\circ} \mathrm{C}$. After stirring at $0{ }^{\circ} \mathrm{C}$ for $5 \mathrm{~min}$, a solution of $\mathbf{3 0}$ (30.4 mg, 0.106 mmol, 1.0 equiv) in THF/ $\mathrm{CH}_{2} \mathrm{Cl}_{2}(0.3 \mathrm{~mL} / 0.8 \mathrm{~mL})$ was added dropwise over the course of 5 min, resulting in a color change from light yellow to green and then to black to be observed. The resulting mixture was then vigorously stirred at $0{ }^{\circ} \mathrm{C}$ for $15 \mathrm{~min}$, at $23{ }^{\circ} \mathrm{C}$ for $20 \mathrm{~min}$, and finally at $33{ }^{\circ} \mathrm{C}$ for $10 \mathrm{~h}$. Upon completion, the resultant viscous mixture was quenched by being poured into aqueous $\mathrm{K}_{2} \mathrm{CO}_{3}(5 \%, 5 \mathrm{~mL})$, followed by the addition of saturated aqueous Rochelle's salt $(20 \mathrm{~mL})$. The resultant black mixture was stirred vigorously at $23{ }^{\circ} \mathrm{C}$ for 16 $\mathrm{h}$ until phase separation occurred, was then poured into a separatory funnel, and the layers were separated. The aqueous layer was then extracted with $\mathrm{CH}_{2} \mathrm{Cl}_{2}(3 \times 2 \mathrm{~mL})$, and the combined organic layers were washed with brine $(4 \mathrm{~mL})$, dried $\left(\mathrm{MgSO}_{4}\right)$, filtered, and concentrated. The resultant residue was purified by flash column chromatography (silica gel, hexanes) to afford $\mathbf{1}\left(16.0 \mathrm{mg}, 53 \%\right.$ yield) as a colorless oil. $\mathbf{1}: \mathrm{R}_{f}=0.80$ (silica gel, hexanes/EtOAc, 4/1); IR (film) $v_{\max } 2951,2867,1456,1386,1367,903,878,668 \mathrm{~cm}^{-1} ;{ }^{1} \mathrm{H}$ $\operatorname{NMR}\left(500 \mathrm{MHz}, \mathrm{CDCl}_{3}\right) \delta 5.28(\mathrm{~s}, 1 \mathrm{H}), 4.93(\mathrm{~s}, 1 \mathrm{H}), 4.65(\mathrm{dd}, J=12.9,4.5 \mathrm{~Hz}, 1 \mathrm{H}), 4.61$ (s, $1 \mathrm{H}), 2.36$ (td, $J=13.8,4.8 \mathrm{~Hz}, 1 \mathrm{H}), 2.27-2.19$ (m, $2 \mathrm{H}), 2.14$ (ddd, $J=13.7,4.8,2.2 \mathrm{~Hz}$, $1 \mathrm{H}), 2.11-2.00$ (m, $2 \mathrm{H}), 1.90-1.84(\mathrm{~m}, 1 \mathrm{H}), 1.79-1.73$ (m, $1 \mathrm{H}), 1.70-1.59$ (m, $2 \mathrm{H}), 1.57$ $(\mathrm{s}, 3 \mathrm{H}), 1.10(\mathrm{~s}, 3 \mathrm{H}), 0.93(\mathrm{~s}, 3 \mathrm{H}) ;{ }^{13} \mathrm{C} \mathrm{NMR}\left(125 \mathrm{MHz}, \mathrm{CDCl}_{3}\right) \delta$ 145.6, 132.7, 119.7, 112.6, 66.1, 47.1, 42.7, 35.7, 33.0, 30.3, 27.6, 25.6, 23.8, 23.1, 17.5; HRMS (APCI+) calcd for $\mathrm{C}_{15} \mathrm{H}_{23} \mathrm{Br}^{+}\left[\mathrm{M}^{+}\right]$282.0978, found 282.0994. 


\begin{tabular}{|c|c|c|c|c|c|}
\hline \multicolumn{3}{|c|}{${ }^{1} \mathrm{H}$ NMR $\left(\mathrm{CDCl}_{3}\right)$} & \multicolumn{3}{|c|}{${ }^{13} \mathrm{C}$ NMR $\left(\mathrm{CDCl}_{3}\right)$} \\
\hline $\begin{array}{c}\text { Natural } \\
10-\beta-B r-c h a \\
\text { migrene }(\mathbf{1})^{6}\end{array}$ & $\begin{array}{c}\text { Synthetic } \\
10-\beta-B r-c h a \\
\text { migrene (1) }\end{array}$ & $\begin{array}{c}\text { Reported } \\
\text { synthetic } \\
\text { 10- } \beta-\mathrm{Br}-\mathrm{cha} \\
\text { migrene }(\mathbf{1})^{7}\end{array}$ & $\begin{array}{c}\text { Natural } \\
10-\beta-B r-c h a \\
\text { migrene }(\mathbf{1})^{6}\end{array}$ & $\begin{array}{c}\text { Synthetic } \\
10-B r-\beta \text {-cha } \\
\text { migrene (1) }\end{array}$ & $\begin{array}{c}\text { Reported } \\
\text { synthetic } \\
10-\beta-B r-c h a \\
\text { migrene }(\mathbf{1})^{7}\end{array}$ \\
\hline $\begin{array}{c}5.28(\mathrm{br} \mathrm{s}, 1 \\
\mathrm{H})\end{array}$ & $5.28(\mathrm{~s}, 1 \mathrm{H})$ & $\begin{array}{c}5.25(\mathrm{br} \mathrm{s}, 1 \\
\mathrm{H})\end{array}$ & 145.6 & 145.6 & 145.8 \\
\hline $\begin{array}{c}4.93(\mathrm{t}, J= \\
1.8 \mathrm{~Hz}, 1 \mathrm{H})\end{array}$ & $4.93(\mathrm{~s}, 1 \mathrm{H})$ & $4.91(\mathrm{~s}, 1 \mathrm{H})$ & 132.7 & 132.7 & 132.9 \\
\hline $\begin{array}{c}4.65(\mathrm{dd}, J= \\
12.7,4.4 \mathrm{~Hz} \\
1 \mathrm{H})\end{array}$ & $\begin{array}{c}4.65(\mathrm{dd}, J= \\
12.9,4.5 \mathrm{~Hz} \\
1 \mathrm{H})\end{array}$ & $\begin{array}{c}4.61(\mathrm{dd}, J= \\
12,4 \mathrm{~Hz} \\
1 \mathrm{H})\end{array}$ & 119.7 & 119.7 & 119.9 \\
\hline $\begin{array}{c}4.61(\mathrm{br}, \mathrm{s}, 1 \\
\mathrm{H})\end{array}$ & $4.61(\mathrm{~s}, 1 \mathrm{H})$ & $4.60(\mathrm{~s}, 1 \mathrm{H})$ & 112.6 & 112.6 & 117.8 \\
\hline $\begin{array}{l}2.37(\mathrm{ddd}, J \\
=13.8,13.8, \\
5.2 \mathrm{~Hz}, 1 \mathrm{H})\end{array}$ & $\begin{array}{c}2.36(\mathrm{td}, J= \\
13.8,4.8 \mathrm{~Hz} \\
1 \mathrm{H})\end{array}$ & & 66.1 & 66.1 & 66.2 \\
\hline $\begin{array}{c}2.23(\mathrm{dddd}, J \\
=12.8,5.2, \\
4.4,2.2 \mathrm{~Hz}, 1 \\
\mathrm{H})\end{array}$ & $\begin{array}{c}2.27-2.19 \\
(\mathrm{~m}, 2 \mathrm{H})\end{array}$ & & 47.0 & 47.1 & 47.2 \\
\hline $\begin{array}{c}2.23(\mathrm{br}, \mathrm{d}, J \\
=15.3 \mathrm{~Hz}, 1 \\
\mathrm{H})\end{array}$ & & & 42.7 & 42.7 & 42.9 \\
\hline $\begin{array}{l}2.14(\mathrm{ddd}, J \\
=13.8,4.8 \\
2.2 \mathrm{~Hz}, 1 \mathrm{H})\end{array}$ & $\begin{array}{l}2.14(\mathrm{ddd}, J \\
=13.7,4.8, \\
2.2 \mathrm{~Hz}, 1 \mathrm{H})\end{array}$ & & 35.7 & 35.7 & 35.9 \\
\hline $\begin{array}{c}2.06 \text { (dddd, } J \\
=13.8,12.8, \\
12.7,4.8 \mathrm{~Hz}, \\
1 \mathrm{H})\end{array}$ & $\begin{array}{c}2.11-2.00 \\
(\mathrm{~m}, 2 \mathrm{H})\end{array}$ & & 33.9 & 33.0 & 33.2 \\
\hline $\begin{array}{c}2.04(\mathrm{br} \mathrm{d}, J \\
=15.3 \mathrm{~Hz}, 1 \\
\mathrm{H})\end{array}$ & & & 30.3 & 30.3 & 30.5 \\
\hline $\begin{array}{l}1.88(\mathrm{dm}, J= \\
10.8 \mathrm{~Hz}, 1 \mathrm{H})\end{array}$ & $\begin{array}{c}1.90-1.84 \\
(\mathrm{~m}, 1 \mathrm{H})\end{array}$ & & 27.5 & 27.6 & 27.7 \\
\hline $1.76(\mathrm{~m}, 1 \mathrm{H})$ & $\begin{array}{c}1.79-1.73 \\
(\mathrm{~m}, 1 \mathrm{H})\end{array}$ & & 25.6 & 25.6 & 25.8 \\
\hline $1.62(\mathrm{~m}, 1 \mathrm{H})$ & $1.70-1.59$ & & 23.9 & 23.8 & 24.0 \\
\hline $1.58(\mathrm{~m}, 1 \mathrm{H})$ & $(\mathrm{m}, 2 \mathrm{H})$ & & 23.1 & 23.1 & 23.3 \\
\hline $\begin{array}{c}1.54 \text { (br s, } 3 \\
\mathrm{H})\end{array}$ & $1.57(\mathrm{~s}, 3 \mathrm{H})$ & $1.56(\mathrm{~s}, 3 \mathrm{H})$ & 17.5 & 17.5 & 17.7 \\
\hline $1.10(\mathrm{~s}, 3 \mathrm{H})$ & $1.10(\mathrm{~s}, 3 \mathrm{H})$ & $1.10(\mathrm{~s}, 3 \mathrm{H})$ & & & \\
\hline $0.94(\mathrm{~s}, 3 \mathrm{H})$ & $0.93(\mathrm{~s}, 3 \mathrm{H})$ & $0.94(\mathrm{~s}, 3 \mathrm{H})$ & & & \\
\hline
\end{tabular}




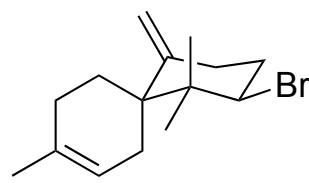

32

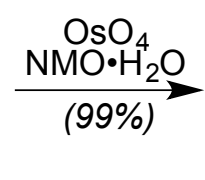

"“'

33

Diol 33. Compound $32(15.0 \mathrm{mg}, 0.053 \mathrm{mmol}, 1.0$ equiv) was dissolved in acetone $(1 \mathrm{~mL})$ and $t-\mathrm{BuOH}(0.2 \mathrm{~mL}), \mathrm{H}_{2} \mathrm{O}(0.2 \mathrm{~mL}), \mathrm{NMO} \cdot \mathrm{H}_{2} \mathrm{O}\left(0.143 \mathrm{~g}, 20\right.$ equiv), and $\mathrm{OsO}_{4}$ $\left(2.5 \%\right.$ in $t$ - $\mathrm{BuOH}, 0.06 \mathrm{~mL}, 0.005 \mathrm{mmol}, 0.1$ equiv) were added sequentially at $23{ }^{\circ} \mathrm{C}$. The resultant mixture was stirred at $23{ }^{\circ} \mathrm{C}$ for $3 \mathrm{~h}$. Upon completion the reaction contents were quenched by the sequential addition of EtOAc $(3 \mathrm{~mL})$ and aqueous $\mathrm{Na}_{2} \mathrm{~S}_{2} \mathrm{O}_{3}(5 \%, 3 \mathrm{~mL})$, poured into a separatory funnel, and the layers were separated. The aqueous layer was extracted with EtOAc $(3 \times 2 \mathrm{~mL})$, and the combined organic layers were washed with brine (3 $\mathrm{mL})$, dried $\left(\mathrm{MgSO}_{4}\right)$, filtered, and concentrated. The resultant residue was purified by flash column chromatography (silica gel, hexanes/EtOAc, 3/1) to afford 33 (16.2 mg, 99\%) as a white solid. Recrystallization of this material from hexanes $/ \mathrm{CH}_{2} \mathrm{Cl}_{2}$ afforded crystals of suitable quality for X-ray diffraction, with the resultant crystal structure shown below in Figure S4. 33: $\mathrm{R}_{f}=0.42$ (silica gel, hexanes/EtOAc, 1/1); m.p. $=117-118^{\circ} \mathrm{C}$; IR (film) $v_{\max }$ 3395 (br), 2971, 1456, 1373, 1265, 1058, 1037, 1018, 906, $739 \mathrm{~cm}^{-1} ;{ }^{1} \mathrm{H}$ NMR $(500 \mathrm{MHz}$, $\left.\mathrm{CDCl}_{3}\right) \delta 5.08(\mathrm{~d}, J=12.1 \mathrm{~Hz}, 1 \mathrm{H}), 4.70(\mathrm{~s}, 1 \mathrm{H}), 4.59(\mathrm{dd}, J=12.8,4.7 \mathrm{~Hz}, 1 \mathrm{H}), 3.22(\mathrm{dd}$, $J=11.7,3.9 \mathrm{~Hz}, 1 \mathrm{H}), 2.45$ (td, $J=13.4,5.3 \mathrm{~Hz}, 1 \mathrm{H}), 2.31-2.24(\mathrm{~m}, 1 \mathrm{H}), 2.13$ (ddd, $J=$ 13.3, 5.3, $1.9 \mathrm{~Hz}, 1 \mathrm{H}), 2.05(\mathrm{td}, J=13.0,5.3 \mathrm{~Hz}, 1 \mathrm{H}), 1.98-1.92(\mathrm{~m}, 1 \mathrm{H}), 1.87(\mathrm{~d}, J=12.2$ $\mathrm{Hz}, 1 \mathrm{H}), 1.82(\mathrm{dd}, J=11.6,2.9 \mathrm{~Hz}, 1 \mathrm{H}), 1.76-1.68(\mathrm{~m}, 2 \mathrm{H}), 1.66-1.60$ (m, $1 \mathrm{H}), 1.21(\mathrm{~s}, 3$ $\mathrm{H}), 1.15(\mathrm{~s}, 3 \mathrm{H}), 0.94(\mathrm{~s}, 3 \mathrm{H}) ;{ }^{13} \mathrm{C} \mathrm{NMR}\left(125 \mathrm{MHz}, \mathrm{CDCl}_{3}\right) \delta$ 146.3, 113.1, 72.2, 71.0, 64.9, 49.2, 43.9, 36.3, 34.2, 33.9, 32.4, 27.1, 23.6, 23.4, 17.2; HRMS (ESI+) calcd for $\mathrm{C}_{15} \mathrm{H}_{24} \mathrm{BrO}^{+}$ $\left[\mathrm{M}-\mathrm{H}_{2} \mathrm{O}+\mathrm{H}^{+}\right] 299.1005$, found 299.1002.

Figure S4. ORTEP representation of 33.

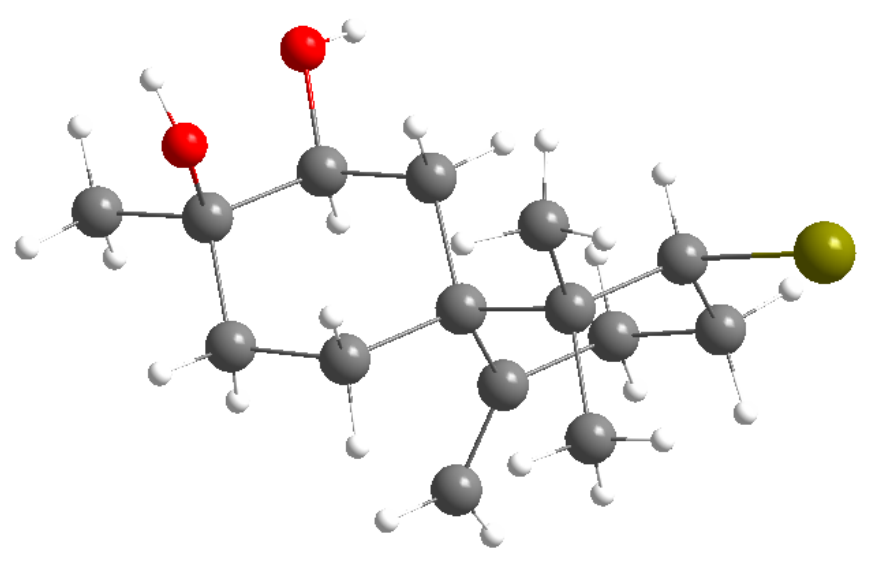


<smiles>C=C1C2CCC1(C(Br)CBr)CC2</smiles>

1

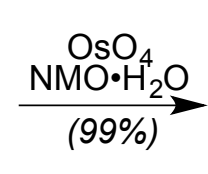

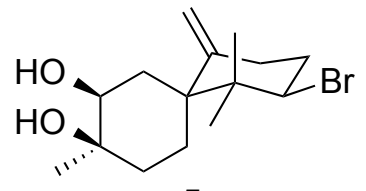

5

3,4-Dihydroxy-10- $\boldsymbol{\beta}$-Chamigrene [proposed structure] (5). Compound $\mathbf{1}$ (4.7 mg, $0.016 \mathrm{mmol}, 1.0$ equiv) was dissolved in acetone $(0.8 \mathrm{~mL})$ and $t-\mathrm{BuOH}(0.1 \mathrm{~mL}), \mathrm{H}_{2} \mathrm{O}(0.1$ $\mathrm{mL}), \mathrm{NMO} \cdot \mathrm{H}_{2} \mathrm{O}\left(30.0 \mathrm{mg}, 20\right.$ equiv) and $\mathrm{OsO}_{4}(2.5$ w.t. $\%$ in $t-\mathrm{BuOH}, 0.02 \mathrm{~mL}, 0.002 \mathrm{mmol}$, 0.1 equiv) were added sequentially at $23{ }^{\circ} \mathrm{C}$. The resultant mixture was stirred at $23{ }^{\circ} \mathrm{C}$ for $8 \mathrm{~h}$. Upon completion, the reaction contents were quenched by the sequential addition of EtOAc $(2 \mathrm{~mL})$ and aqueous $\mathrm{Na}_{2} \mathrm{~S}_{2} \mathrm{O}_{3}(5 \%, 2 \mathrm{~mL})$, poured into a separatory funnel, and the layers were separated. The aqueous layer was extracted with EtOAc $(3 \times 2 \mathrm{~mL})$, and the combined organic layers were washed with brine $(3 \mathrm{~mL})$, dried $\left(\mathrm{MgSO}_{4}\right)$, filtered, and concentrated. The resultant residue was purified by flash column chromatography (silica gel, hexanes/EtOAc, 3/1) to afford 5 (4.7 mg, 99\% yield) as a white solid. Recrystallization of this material from hexanes $/ \mathrm{CH}_{2} \mathrm{Cl}_{2}$ afforded crystals of suitable quality for X-ray diffraction, with the resultant crystal structure shown below in Figure S5. 5: $\mathrm{R}_{f}=0.41$ (silica gel, hexanes/EtOAc, 1/1); m.p. $=138-139{ }^{\circ} \mathrm{C}$; IR (film) $v_{\max } 3333$ (br), 2967, 2926, 1456, 1448, 1060, 1028, 901, 869, $738 \mathrm{~cm}^{-1} ;{ }^{1} \mathrm{H}$ NMR (500 MHz, $\left.\mathrm{CDCl}_{3}\right) \delta 5.12(\mathrm{~s}, 1 \mathrm{H}), 4.85$ (s, 1 H), $4.58(\mathrm{dd}, J=12.7,4.6 \mathrm{~Hz}, 1 \mathrm{H}), 3.74(\mathrm{dd}, J=11.3,5.0 \mathrm{~Hz}, 1 \mathrm{H}), 2.36-2.22(\mathrm{~m}, 2 \mathrm{H})$, 2.12-1.99 (m, 2 H), 1.96-1.87 (m, $2 \mathrm{H}), 1.74-1.70$ (m, $1 \mathrm{H}), 1.68-1.65$ (m, $1 \mathrm{H}), 1.60-1.54$ $(\mathrm{m}, 2 \mathrm{H}), 1.21(\mathrm{~s}, 3 \mathrm{H}), 1.16(\mathrm{~s}, 3 \mathrm{H}), 0.97(\mathrm{~s}, 3 \mathrm{H}) ;{ }^{13} \mathrm{C} \mathrm{NMR}\left(125 \mathrm{MHz}, \mathrm{CDCl}_{3}\right) \delta$ 147.0, 113.6, 71.8, 70.6, 64.9, 49.8, 43.8, 36.1, 33.8, 33.4, 33.3, 27.3, 23.7, 22.7, 17.5; HRMS (Mixed+) calcd for $\mathrm{C}_{15} \mathrm{H}_{24} \mathrm{BrO}^{+}\left[\mathrm{M}-\mathrm{H}_{2} \mathrm{O}+\mathrm{H}^{+}\right] 299.1005$, found 299.0994.

\section{${ }^{1} \mathrm{H}$ NMR $\left(\mathrm{C}_{6} \mathrm{D}_{6}\right)$ (selected peaks)}

\begin{tabular}{cc}
\hline $\begin{array}{c}\text { Natural "3,4-dihydroxy-10- } \\
\beta \text {-bromo-chamigrane" }\end{array}$ & $\begin{array}{c}\text { Synthetic 3,4-dihydroxy-10- } \\
\beta \text {-bromo-chamigrane }\end{array}$ \\
\hline $4.73(\mathrm{t}, J=1.3 \mathrm{~Hz}, 1 \mathrm{H})$ & $4.81(\mathrm{~s}, 1 \mathrm{H})$ \\
$4.46(\mathrm{br} \mathrm{s}, 1 \mathrm{H})$ & $4.57(\mathrm{~s}, 1 \mathrm{H})$ \\
$4.12(\mathrm{dd}, J=12.3,5.1 \mathrm{~Hz}, 1 \mathrm{H})$ & $4.24(\mathrm{dd}, J=12.6,4.9 \mathrm{~Hz}, 1 \mathrm{H})$ \\
$4.12(\mathrm{dd}, J=5.1,12.3 \mathrm{~Hz}, 1 \mathrm{H})$ & $3.45(\mathrm{dd}, J=10.7,4.8 \mathrm{~Hz}, 1 \mathrm{H})$ \\
$1.05(\mathrm{~s}, 3 \mathrm{H})$ & $1.03(\mathrm{~s}, 3 \mathrm{H})$ \\
$1.07(\mathrm{~s}, 3 \mathrm{H})$ & $1.14(\mathrm{~s}, 3 \mathrm{H})$ \\
$0.87(\mathrm{~s}, 3 \mathrm{H})$ & $0.97(\mathrm{~s}, 3 \mathrm{H})$ \\
\hline
\end{tabular}


Figure S5. ORTEP representation of $\mathbf{5}$.

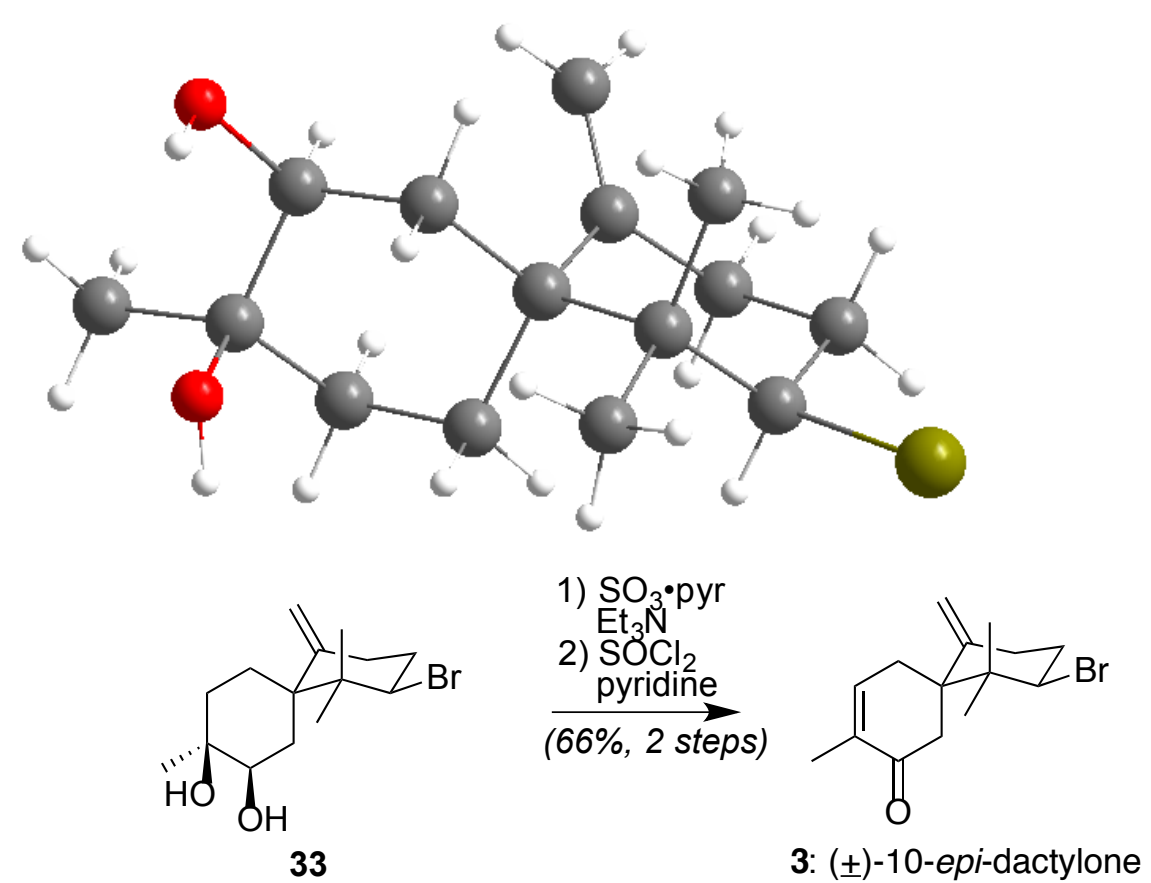

( \pm -10-epi-Dactylone (3). Compound $33(5.0 \mathrm{mg}, 0.016 \mathrm{mmol}, 1.0$ equiv) was dissolved in a mixture of $\mathrm{CH}_{2} \mathrm{Cl}_{2} / \mathrm{DMSO} / \mathrm{Et}_{3} \mathrm{~N}(0.3 \mathrm{~mL} / 0.3 \mathrm{~mL} / 0.05 \mathrm{~mL})$, the solution was cooled to $0{ }^{\circ} \mathrm{C}$, and $\mathrm{SO}_{3} \bullet$ pyr $(7.6 \mathrm{mg}, 0.048 \mathrm{mmol}, 3.0$ equiv) was added. The resultant mixture was stirred at $0{ }^{\circ} \mathrm{C}$ for $1 \mathrm{~h}$. Upon completion, the reaction contents were quenched by the addition of aqueous $\mathrm{HCl}(2 \mathrm{M}, 3 \mathrm{~mL})$, poured into a separatory funnel, and the layers were separated. The aqueous layer was extracted with $\mathrm{CH}_{2} \mathrm{Cl}_{2}(3 \times 2 \mathrm{~mL})$. The combined organic layers were washed with brine $(2 \mathrm{~mL})$, dried $\left(\mathrm{MgSO}_{4}\right)$, filtered, and concentrated to give the crude hydroxyketone $\left(\mathrm{R}_{f}=0.66\right.$, hexanes/EtOAc, $\left.1 / 1\right)$ that was used without any further purification. Next, the crude hydroxyketone $(0.016 \mathrm{mmol}$ assumed, 1.0 equiv) was dissolved in pyridine $(0.5 \mathrm{~mL})$, the resultant solution was cooled to $0{ }^{\circ} \mathrm{C}$, and $\mathrm{SOCl}_{2}(3.0 \mu \mathrm{L}$, $0.032 \mathrm{mmol}, 2.0$ equiv) was added. The reaction mixture was then stirred at $0{ }^{\circ} \mathrm{C}$ for $20 \mathrm{~min}$. Upon completion, the reaction contents were quenched by the sequential addition of $\mathrm{CH}_{2} \mathrm{Cl}_{2}$ $(2 \mathrm{~mL})$ and aqueous $\mathrm{HCl}(2 \mathrm{M}, 3 \mathrm{~mL})$, poured into a separatory funnel, and the layers were separated. The aqueous layer was extracted with $\mathrm{CH}_{2} \mathrm{Cl}_{2}(3 \times 2 \mathrm{~mL})$, and then the combined organic layers were washed with brine $(2 \mathrm{~mL})$, dried $\left(\mathrm{MgSO}_{4}\right)$, filtered, and concentrated. Purification of the resultant residue using preparative thin-layer chromatography (silica gel, hexanes/EtOAc, 3/1) afforded 10-epi-dactylone (3,3.1 mg, 66\% yield over 2 steps) as a white solid. 3: $\mathrm{R}_{f}=0.49$ (silica gel, hexanes/EtOAc, 4/1); IR (film) $v_{\max } 2976,2924,1675,1456$, 1369, 1213, 907, $795 \mathrm{~cm}^{-1}$; ${ }^{1} \mathrm{H}$ NMR (500 MHz, $\left.\mathrm{CDCl}_{3}\right) \delta 6.66-6.59(\mathrm{~m}, 1 \mathrm{H}), 4.98(\mathrm{~s}, 1 \mathrm{H})$, $4.54(\mathrm{~s}, 1 \mathrm{H}), 4.48(\mathrm{dd}, J=12.6,4.5 \mathrm{~Hz}, 1 \mathrm{H}), 2.80(\mathrm{dd}, J=14.9,2.3 \mathrm{~Hz}, 1 \mathrm{H}), 2.71-2.61(\mathrm{~m}$, $2 \mathrm{H}), 2.52(\mathrm{dd}, J=18.3,5.2 \mathrm{~Hz}, 1 \mathrm{H}), 2.42(\mathrm{td}, J=13.8,5.0 \mathrm{~Hz}, 1 \mathrm{H}), 2.28-2.21(\mathrm{~m}, 1 \mathrm{H})$, 2.14 (ddd, $J=14.1,4.8,2.6 \mathrm{~Hz}, 1 \mathrm{H}), 2.04$ (ddd, $J=26.2,13.0,5.0 \mathrm{~Hz}, 1 \mathrm{H}), 1.70$ (d, $J=1.2$ $\mathrm{Hz}, 3 \mathrm{H}), 1.19$ (s, $3 \mathrm{H}), 0.99$ (s, $3 \mathrm{H}) ;{ }^{13} \mathrm{C} \mathrm{NMR}\left(125 \mathrm{MHz}, \mathrm{CDCl}_{3}\right) \delta$ 198.4, 144.1, 143.1, 134.5, 114.7, 63.6, 51.7, 43.0 (2 C), 35.2, 32.5, 31.6, 24.7, 17.2, 15.3; HRMS (APCI+) calcd 
for $\mathrm{C}_{15} \mathrm{H}_{22} \mathrm{BrO}^{+}\left[\mathrm{M}+\mathrm{H}^{+}\right]$297.0849, found 297.0840.

\begin{tabular}{|c|c|c|c|}
\hline \multicolumn{2}{|c|}{${ }^{1} \mathrm{H}$ NMR $\left(\mathrm{CDCl}_{3}\right)$} & \multicolumn{2}{|c|}{${ }^{13} \mathrm{C} \mathrm{NMR}\left(\mathrm{CDCl}_{3}\right)$} \\
\hline $\begin{array}{c}\text { Natural } \\
\text { 10-epi-dacylone }(\mathbf{3})^{8}\end{array}$ & $\begin{array}{c}\text { Synthetic } \\
\text { 10-epi-dacylone (3) }\end{array}$ & $\begin{array}{c}\text { Natural } \\
\text { 10-epi-dacylone }(\mathbf{3})^{8}\end{array}$ & $\begin{array}{c}\text { Synthetic } \\
\text { 10-epi-dacylone (3) }\end{array}$ \\
\hline $6.63(\mathrm{~m}, 1 \mathrm{H})$ & $6.66-6.59(\mathrm{~m}, 1 \mathrm{H})$ & 198.2 & 198.4 \\
\hline $5.00(\mathrm{br}, \mathrm{s}, 1 \mathrm{H})$ & $4.98(\mathrm{~s}, 1 \mathrm{H})$ & 144.3 & 144.1 \\
\hline $4.54(\mathrm{~s}, 1 \mathrm{H})$ & $4.54(\mathrm{~s}, 1 \mathrm{H})$ & 142.9 & 143.1 \\
\hline $4.48(\mathrm{dd}, J=12.4,4.5$ & $4.48(\mathrm{dd}, J=12.6,4.5$ & 134.6 & 134.5 \\
\hline $\mathrm{Hz}, 1 \mathrm{H})$ & $\mathrm{Hz}, 1 \mathrm{H})$ & & \\
\hline $2.81(\mathrm{dd}, J=14.9,2.3$ & $2.80(\mathrm{dd}, J=14.9,2.3$ & 114.6 & 114.7 \\
\hline $\mathrm{Hz}, 1 \mathrm{H})$ & $\mathrm{Hz}, 1 \mathrm{H})$ & & \\
\hline $\begin{array}{c}2.67(\mathrm{dm}, J=18.9 \mathrm{~Hz} \\
1 \mathrm{H})\end{array}$ & $2.71-2.61(\mathrm{~m}, 2 \mathrm{H})$ & 63.6 & 63.6 \\
\hline $\begin{array}{c}2.65(\mathrm{~d}, J=14.9 \mathrm{~Hz}, 1 \\
\mathrm{H})\end{array}$ & & 51.8 & 51.7 \\
\hline $\begin{array}{c}2.53(\mathrm{dm}, J=18.9 \mathrm{~Hz} \\
1 \mathrm{H})\end{array}$ & $\begin{array}{c}2.52(\mathrm{dd}, J=18.3,5.2 \\
\mathrm{Hz}, 1 \mathrm{H})\end{array}$ & 43.15 & $\begin{array}{c}43.0 \text { (two overlapping } \\
\text { signals) }\end{array}$ \\
\hline $2.42(\mathrm{~m}, 1 \mathrm{H})$ & $\begin{array}{c}2.42(\operatorname{td}, J=13.8,5.0 \\
\mathrm{Hz}, 1 \mathrm{H})\end{array}$ & 43.1 & \\
\hline $2.25(\mathrm{~m}, 1 \mathrm{H})$ & $2.28-2.21(\mathrm{~m}, 1 \mathrm{H})$ & 35.4 & 35.2 \\
\hline $2.15(\mathrm{~m}, 1 \mathrm{H})$ & $\begin{array}{c}2.14(\mathrm{ddd}, J=14.1 \\
4.8,2.6 \mathrm{~Hz}, 1 \mathrm{H})\end{array}$ & 32.6 & 32.5 \\
\hline $2.03(\mathrm{~m}, 1 \mathrm{H})$ & $\begin{array}{c}2.04(\mathrm{ddd}, J=26.2 \\
13.0,5.0 \mathrm{~Hz}, 1 \mathrm{H})\end{array}$ & 31.7 & 31.6 \\
\hline $1.71(\mathrm{dt}, J=2.6,1.4$ & $1.70(\mathrm{~d}, J=1.2 \mathrm{~Hz}, 3$ & 24.8 & 24.7 \\
\hline $\mathrm{Hz}, 3 \mathrm{H})$ & $\mathrm{H})$ & & \\
\hline $1.20(\mathrm{~s}, 3 \mathrm{H})$ & $1.19(\mathrm{~s}, 3 \mathrm{H})$ & 17.3 & 17.2 \\
\hline $1.00(\mathrm{~s}, 3 \mathrm{H})$ & $0.99(\mathrm{~s}, 3 \mathrm{H})$ & 15.2 & 15.3 \\
\hline
\end{tabular}
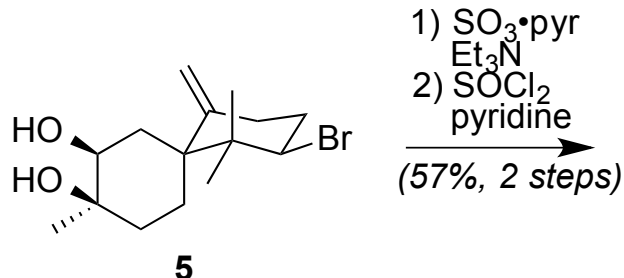

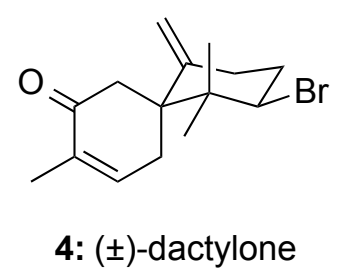

4: ( \pm )-dactylone

( \pm )-Dactylone (4). Compound 5 ( $1.5 \mathrm{mg}, 0.005 \mathrm{mmol}, 1.0$ equiv) was dissolved in a mixture of $\mathrm{CH}_{2} \mathrm{Cl}_{2} / \mathrm{DMSO} / \mathrm{Et}_{3} \mathrm{~N}(0.2 \mathrm{~mL} / 0.2 \mathrm{~mL} / 0.03 \mathrm{~mL})$, the solution was cooled to $0{ }^{\circ} \mathrm{C}$, and $\mathrm{SO}_{3} \bullet \operatorname{pyr}(2.4 \mathrm{mg}, 0.015 \mathrm{mmol}, 3.0$ equiv) was added. The resultant mixture was stirred at $0{ }^{\circ} \mathrm{C}$ for $1 \mathrm{~h}$. Upon completion, the reaction contents were quenched by the addition of aqueous $\mathrm{HCl}(2 \mathrm{M}, 2 \mathrm{~mL})$, poured into a separatory funnel, and the layers were separated. The aqueous layer was extracted with $\mathrm{CH}_{2} \mathrm{Cl}_{2}(3 \times 1.5 \mathrm{~mL})$. The combined organic layers were washed with brine $(2 \mathrm{~mL})$, dried $\left(\mathrm{MgSO}_{4}\right)$, filtered, and concentrated to give the crude 
hydroxyketone $\left(\mathrm{R}_{f}=0.66\right.$, hexanes/EtOAc, $\left.1 / 1\right)$ that was used without any further purification. Next, the crude hydroxyketone $(0.005 \mathrm{mmol}$ assumed, 1.0 equiv) was dissolved in pyridine $(0.3 \mathrm{~mL})$, the resultant solution was cooled to $0{ }^{\circ} \mathrm{C}$, and $\mathrm{SOCl}_{2}(1.6 \mu \mathrm{L}, 0.015$ mmol, 3.0 equiv) was added. The reaction mixture was then stirred at $0{ }^{\circ} \mathrm{C}$ for $15 \mathrm{~min}$. Upon completion, the reaction contents were quenched by the sequential addition of $\mathrm{CH}_{2} \mathrm{Cl}_{2}$ $(1.5 \mathrm{~mL})$ and aqueous $\mathrm{HCl}(2 \mathrm{M}, 2 \mathrm{~mL})$, poured into a separatory funnel, and the layers were separated. The aqueous layer was extracted with $\mathrm{CH}_{2} \mathrm{Cl}_{2}(3 \times 1.5 \mathrm{~mL})$, and then the combined organic layers were washed by brine $(2 \mathrm{~mL})$, dried $\left(\mathrm{MgSO}_{4}\right)$, filtered, and concentrated. Purification of the resultant residue using preparative thin-layer chromatography (silica gel, hexanes/EtOAc, 3/1) afforded dactylone (4, $0.8 \mathrm{mg}, 57 \%$ over 2 steps) as a white solid. $\quad 4: \mathrm{R}_{f}=0.49$ (silica gel, hexanes/EtOAc, 4/1); IR (film) $v_{\max } 2924$, 1671, 1450, 1371, 1113, 905, 872, $782 \mathrm{~cm}^{-1} ;{ }^{1} \mathrm{H}$ NMR (500 MHz, $\left.\mathrm{CDCl}_{3}\right) \delta 6.52-6.48$ (m, 1 H), $4.97(\mathrm{~s}, 1 \mathrm{H}), 4.60(\mathrm{~s}, 1 \mathrm{H}), 4.53(\mathrm{dd}, J=12.6,4.5 \mathrm{~Hz}, 1 \mathrm{H}), 2.75(\mathrm{~d}, J=16.4 \mathrm{~Hz}, 1 \mathrm{H})$, $2.65(\mathrm{~d}, J=1.8 \mathrm{~Hz}, 2 \mathrm{H}), 2.56(\mathrm{dd}, J=16.6,9.0 \mathrm{~Hz}, 1 \mathrm{H}), 2.36(\mathrm{td}, J=13.6,5.4 \mathrm{~Hz}, 1 \mathrm{H})$, 2.30-2.22 (m, $1 \mathrm{H}), 2.16(\mathrm{dd}, J=15.0,6.1 \mathrm{~Hz}, 1 \mathrm{H}), 2.09$ (ddd, $J=26.2,12.9,5.3 \mathrm{~Hz}, 1 \mathrm{H})$, $1.73(\mathrm{~d}, J=1.4 \mathrm{~Hz}, 3 \mathrm{H}), 1.19$ (s, $3 \mathrm{H}), 0.99$ (s, $3 \mathrm{H}) ;{ }^{13} \mathrm{C}$ NMR $\left(125 \mathrm{MHz}, \mathrm{CDCl}_{3}\right) \delta 199.5$, 146.0, 141.4, 135.3, 63.1, 51.2, 44.0, 43.1, 35.2, 33.6, 29.7, 25.0, 17.5, 15.3; HRMS (APCI+) calcd for $\mathrm{C}_{15} \mathrm{H}_{22} \mathrm{BrO}^{+}\left[\mathrm{M}+\mathrm{H}^{+}\right]$297.0849, found 297.0844 .

\begin{tabular}{|c|c|c|c|}
\hline \multicolumn{2}{|c|}{${ }^{1} \mathrm{H}$ NMR $\left(\mathrm{CDCl}_{3}\right)$} & \multicolumn{2}{|c|}{${ }^{13} \mathrm{C} \mathrm{NMR}\left(\mathrm{CDCl}_{3}\right)$} \\
\hline Natural dactylone $(\mathbf{4})^{9}$ & Synthetic dactylone (4) & $\begin{array}{c}\text { Natural dactylone } \\
(\mathbf{4})^{9}\end{array}$ & $\begin{array}{l}\text { Synthetic dactylone } \\
\text { (4) }\end{array}$ \\
\hline $6.50(\mathrm{~m}, 1 \mathrm{H})$ & $6.52-6.48(\mathrm{~m}, 1 \mathrm{H})$ & 198.8 & 199.5 \\
\hline $\begin{array}{c}4.98(\mathrm{br}, \mathrm{d}, J=1.5 \mathrm{~Hz}, \\
1 \mathrm{H})\end{array}$ & $4.97(\mathrm{~s}, 1 \mathrm{H})$ & 146.1 & 146.0 \\
\hline $4.61(\mathrm{~s}, 1 \mathrm{H})$ & $4.60(\mathrm{~s}, 1 \mathrm{H})$ & 140.7 & 141.4 \\
\hline $4.52(\mathrm{dd}, J=12.5,4.5$ & $4.53(\mathrm{dd}, J=12.6,4.5$ & 135.5 & 135.3 \\
\hline $\mathrm{Hz}, 1 \mathrm{H})$ & $\mathrm{Hz}, 1 \mathrm{H})$ & & \\
\hline $2.74(\mathrm{br}, \mathrm{d}, J=16.5$ & $2.75(\mathrm{~d}, J=16.4 \mathrm{~Hz}, 1$ & 63.0 & 63.1 \\
\hline $\mathrm{Hz}, 1 \mathrm{H})$ & $\mathrm{H})$ & & \\
\hline $2.65(\mathrm{~m}, 2 \mathrm{H})$ & $\begin{array}{c}2.65(\mathrm{~d}, J=1.8 \mathrm{~Hz}, 2 \\
\mathrm{H})\end{array}$ & 51.4 & 51.2 \\
\hline $2.57(\mathrm{~d}, J=16.5 \mathrm{~Hz}, 1$ & $2.56(\mathrm{dd}, J=16.6,9.0$ & 44.2 & 44.0 \\
\hline $\mathrm{H})$ & $\mathrm{Hz}, 1 \mathrm{H})$ & & \\
\hline $2.37(\mathrm{~m}, 1 \mathrm{H})$ & $\begin{array}{c}2.36(\operatorname{td}, J=13.6,5.4 \\
\mathrm{Hz}, 1 \mathrm{H})\end{array}$ & 43.2 & 43.1 \\
\hline $2.26(\mathrm{~m}, 1 \mathrm{H})$ & $2.30-2.22(\mathrm{~m}, 1 \mathrm{H})$ & 35.5 & 35.2 \\
\hline $2.17(\mathrm{~m}, 1 \mathrm{H})$ & $\begin{array}{c}2.16(\mathrm{dd}, J=15.0,6.1 \\
\mathrm{Hz}, 1 \mathrm{H})\end{array}$ & 33.7 & 33.6 \\
\hline $2.11(\mathrm{~m}, 1 \mathrm{H})$ & $\begin{array}{c}2.09(\mathrm{ddd}, J=26.2 \\
12.9,5.3 \mathrm{~Hz}, 1 \mathrm{H})\end{array}$ & 30.0 & 29.7 \\
\hline $\begin{array}{c}1.73(\mathrm{~d}, J=1.8 \mathrm{~Hz}, 3 \\
\mathrm{H})\end{array}$ & $\begin{array}{c}1.73(\mathrm{~d}, J=1.4 \mathrm{~Hz}, 3 \\
\mathrm{H})\end{array}$ & 25.1 & 25.0 \\
\hline $1.19(\mathrm{~s}, 3 \mathrm{H})$ & $1.19(\mathrm{~s}, 3 \mathrm{H})$ & 17.7 & 17.5 \\
\hline $0.99(\mathrm{~s}, 3 \mathrm{H})$ & $0.99(\mathrm{~s}, 3 \mathrm{H})$ & 15.3 & 15.3 \\
\hline
\end{tabular}




\section{References}

1. Z. Liu, L. Peng, T. Zhang, Y. Li, Synth. Commun. 2001, 31, 2549-2555.

2. R. B. Lettan II, B. C. Milgram, K. A. Scheidt, Org. Synth. 2007, 84, 22-31.

3. L. A. Gorthey, M. Vairamani, C. Djerassi, J. Org. Chem. 1985, 50, 4173-4182.

4. A. J. Burckle, V. H. Valsilev, N. Z. Burns, Angew. Chem. Int. Ed. 2016, doi: 10.1002/anie.201605722.

5. K. Mori, H. Watanabe, Tetrahedron 1986, 42, 273-281.

6. G. M. Konig, A. D. Wright, Phytochem. Anal. 1997, 8, 167-172.

7. J. D. Martin, C. Pérez, J. L. Ravelo, J. Am. Chem. Soc. 1986, 108, 7801-7811.

8. L. K. Shubina, S. N. Fedorov, A. I. Kalinovsky, A. S. Dmitrenok, J. O. Jin, M. G. Song, J. Y. Kwak, V. A. Stonik, Russ. Chem. Bull. 2007, 56, 2109-2114.

9. E. G. Lyakhova, S. N. Fedorov, L. K. Shubina, O. S. Radchenko, A. I. Kalinovsky, P. S. Dvitrenok, V. A. Stonik, Russ. Chem. Bull. 2003, 52, 1022-1026. 


\title{
Strategies for the Total Synthesis of Diverse Bromo-Chamigrenes
}

\author{
Minxing Shen, ${ }^{1,2}$ Manuel Kretschmer, ${ }^{3}$ Zachary G. Brill, ${ }^{3}$ and Scott A. Snyder ${ }^{1,2,3 *}$ \\ ${ }^{1}$ Dept. of Chemistry, University of Chicago, 5735 South Ellis Avenue, Chicago, IL 60637 \\ ${ }^{2}$ Dept. of Chemistry, The Scripps Research Institute, 130 Scripps Way, Jupiter, FL 33458 \\ ${ }^{3}$ Dept. of Chemistry, Columbia University, 3000 Broadway, New York, NY 10027
}

\section{Supporting Information}

\section{${ }^{1} \mathrm{H}$ and ${ }^{13} \mathrm{C}$ Spectra of Selected Intermediates}



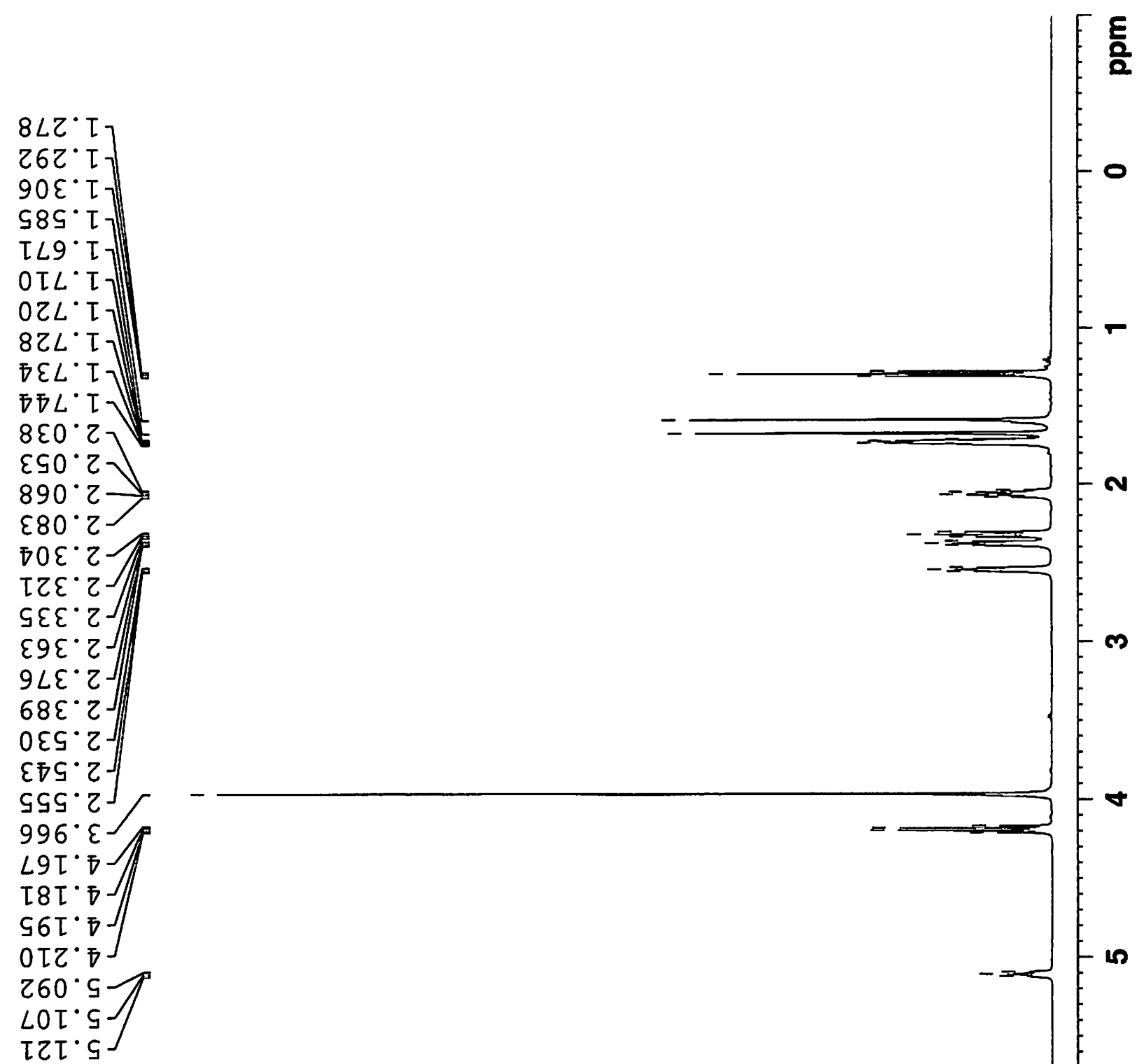

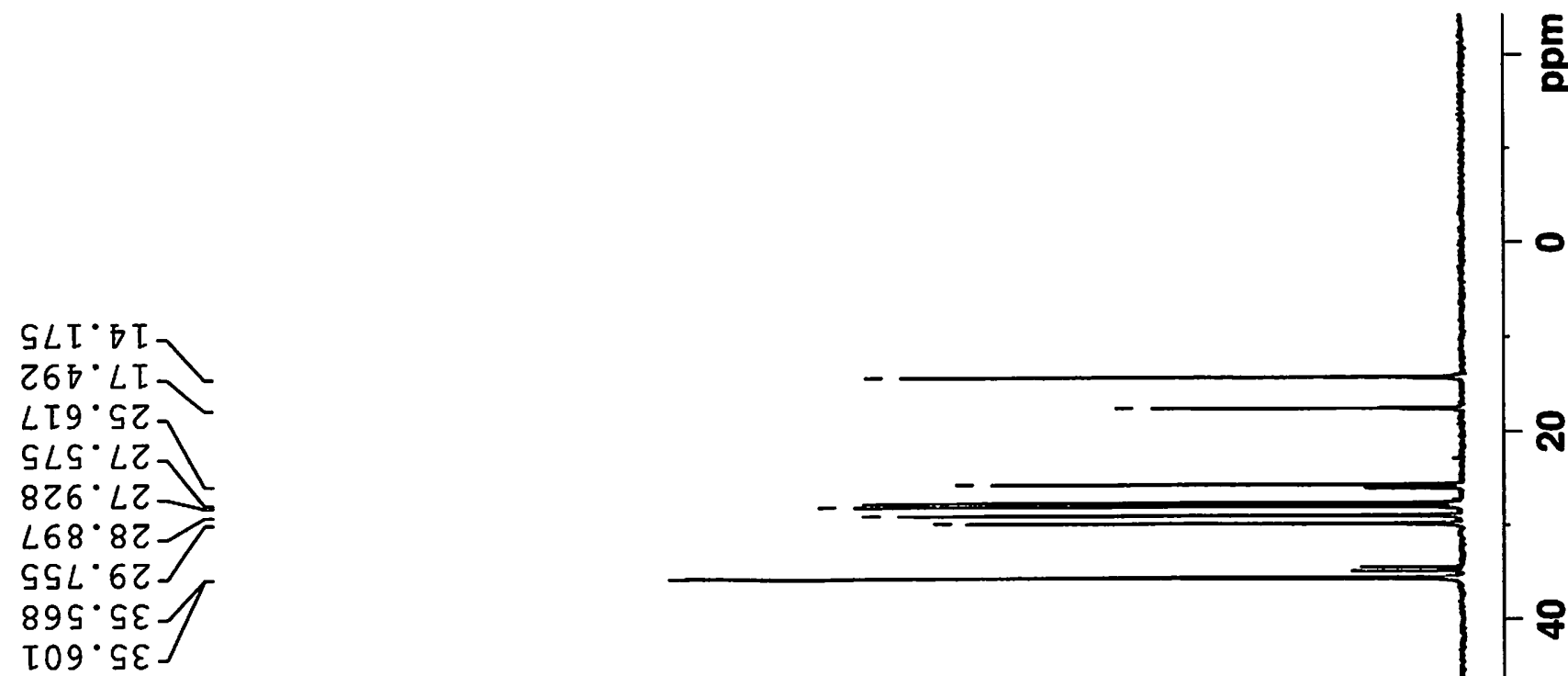

0દ0.09

५ $82^{\circ} 69$

$562 \cdot 80 I$

万ZZ・五I

$60 \sigma^{\circ} \varepsilon Z I_{-}$

$\varepsilon 0 \nabla^{\circ} 9 Z \mathrm{~L}$

LSI'ZEI-

$06 \varepsilon^{\circ} \nabla \sigma \tau$

$2 Z 0^{\circ} O L I-$
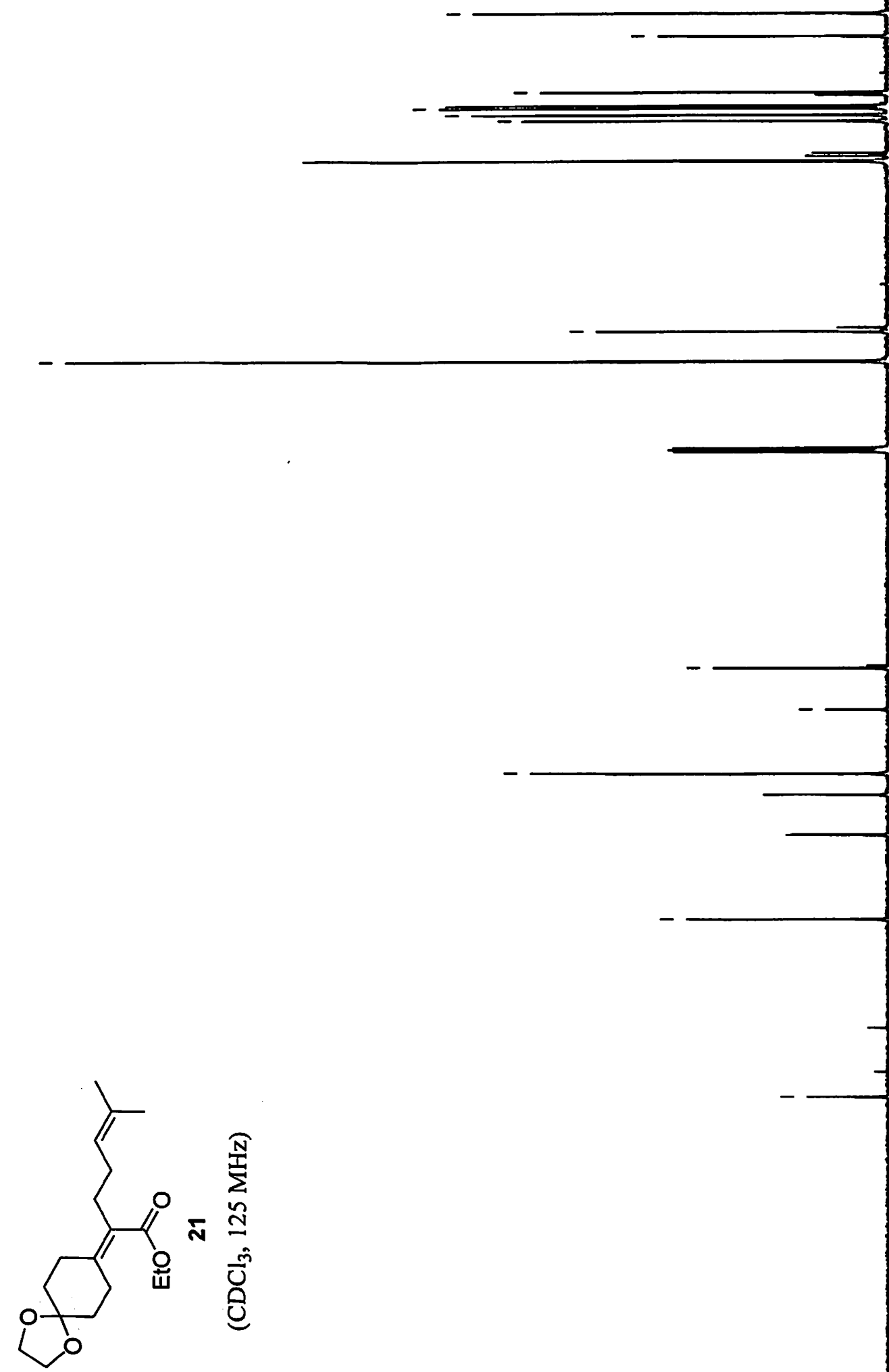

요

요

8

8

오

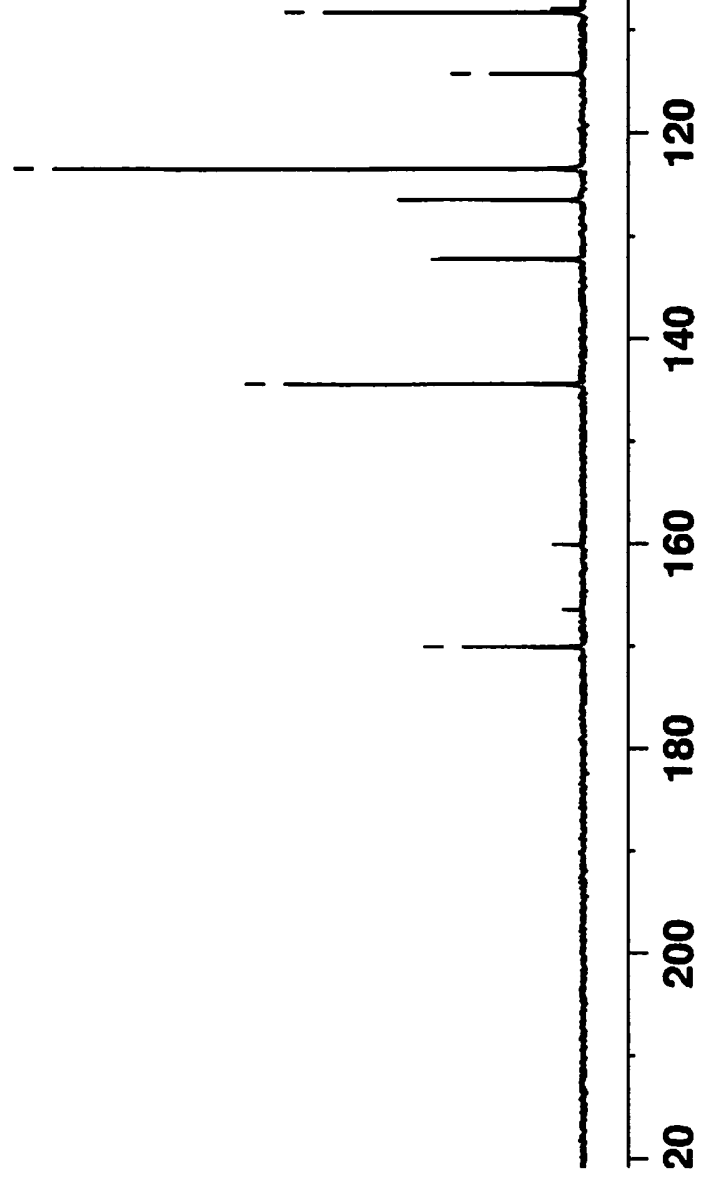




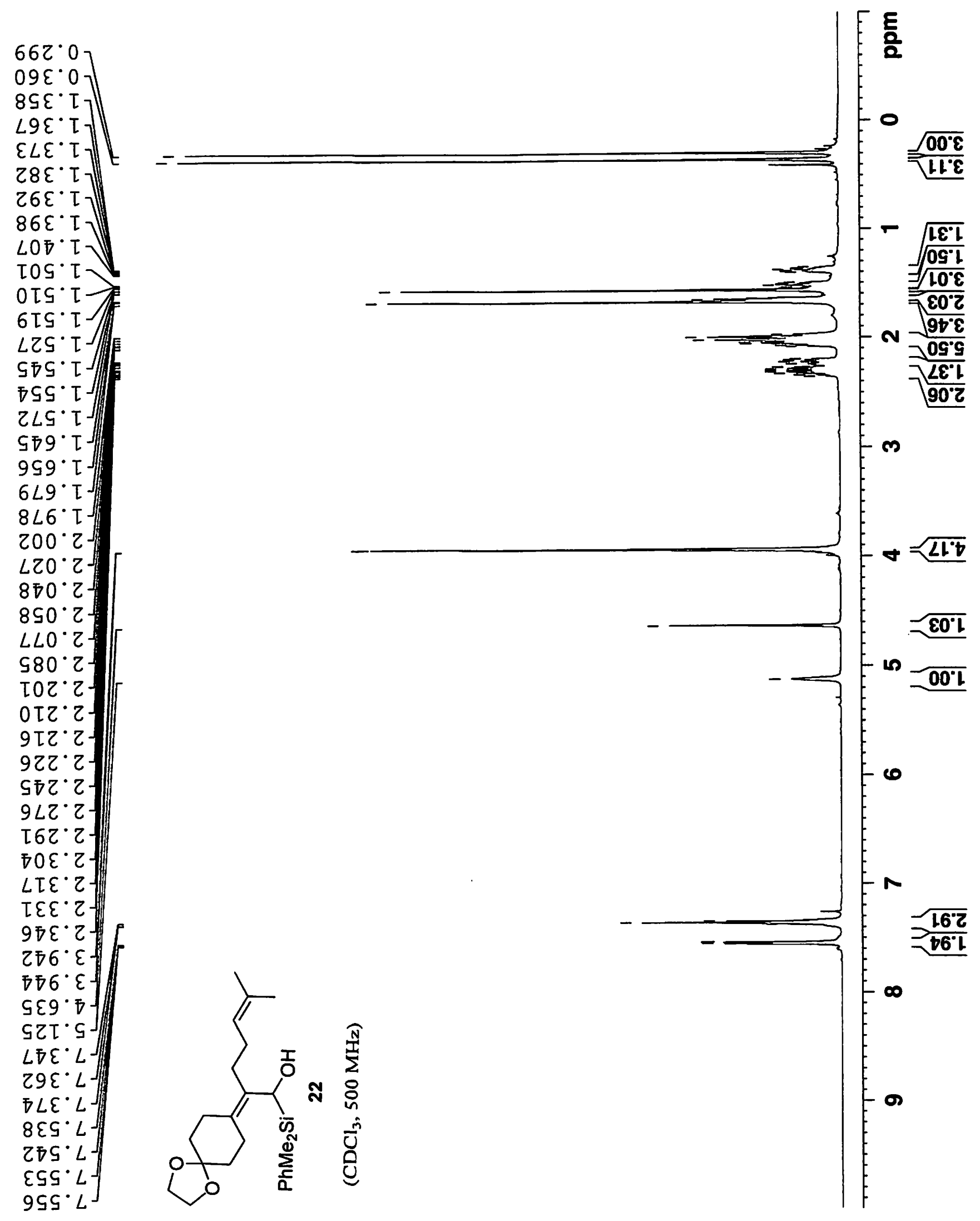


$0<9 \cdot 6->$
$S[2 \cdot 6->$

ZIL LI $S L 9^{\circ} S Z$
$Z T I^{\circ} L Z$ $829^{\circ} \angle 2 \perp$ $\varepsilon 65^{\circ} 627$ $6 \varepsilon 8.62$ ธऽ. $\varsigma \varepsilon$ [I6 ${ }^{\circ} S \mathcal{E}$ ]

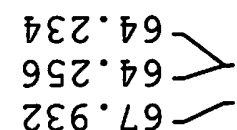

$\tau Z 8 \cdot 80 \tau$

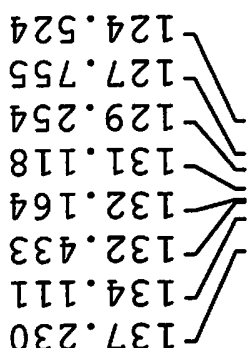

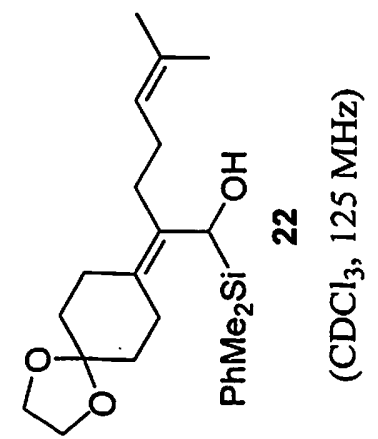

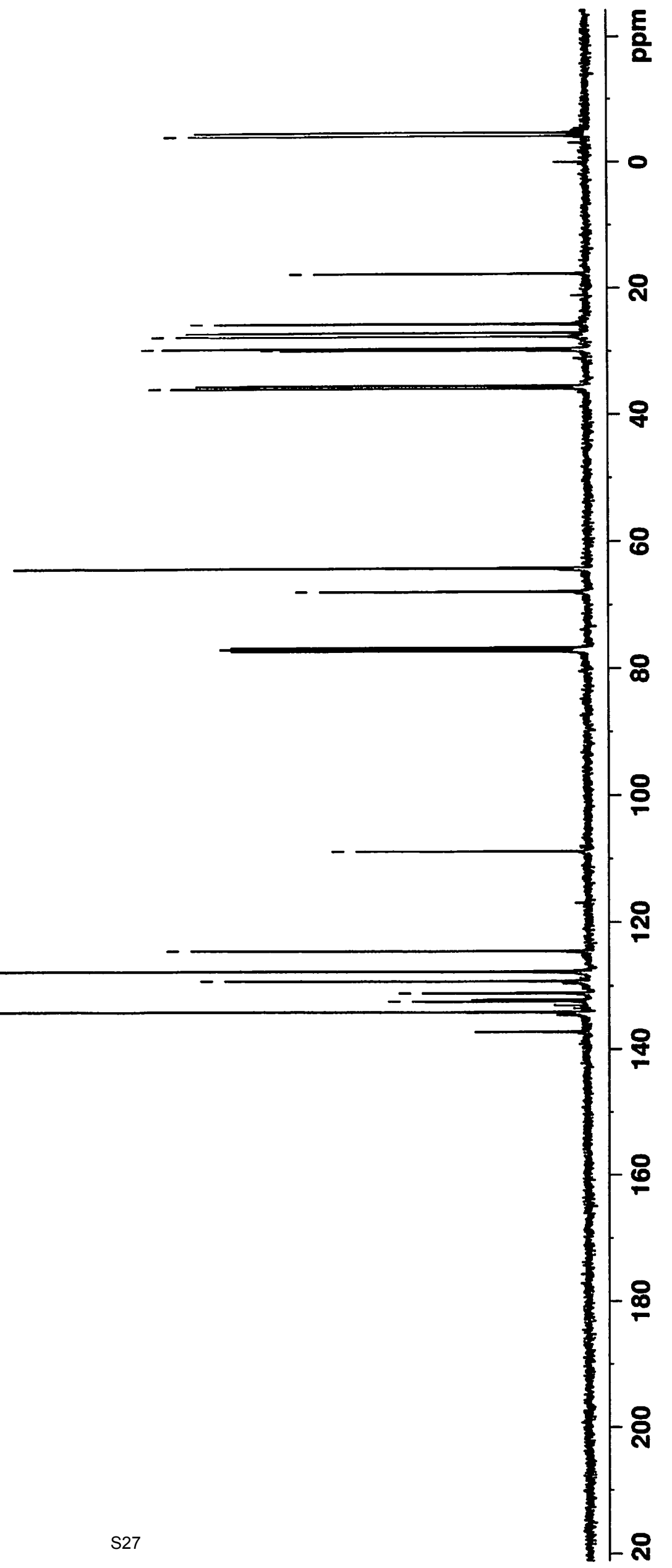




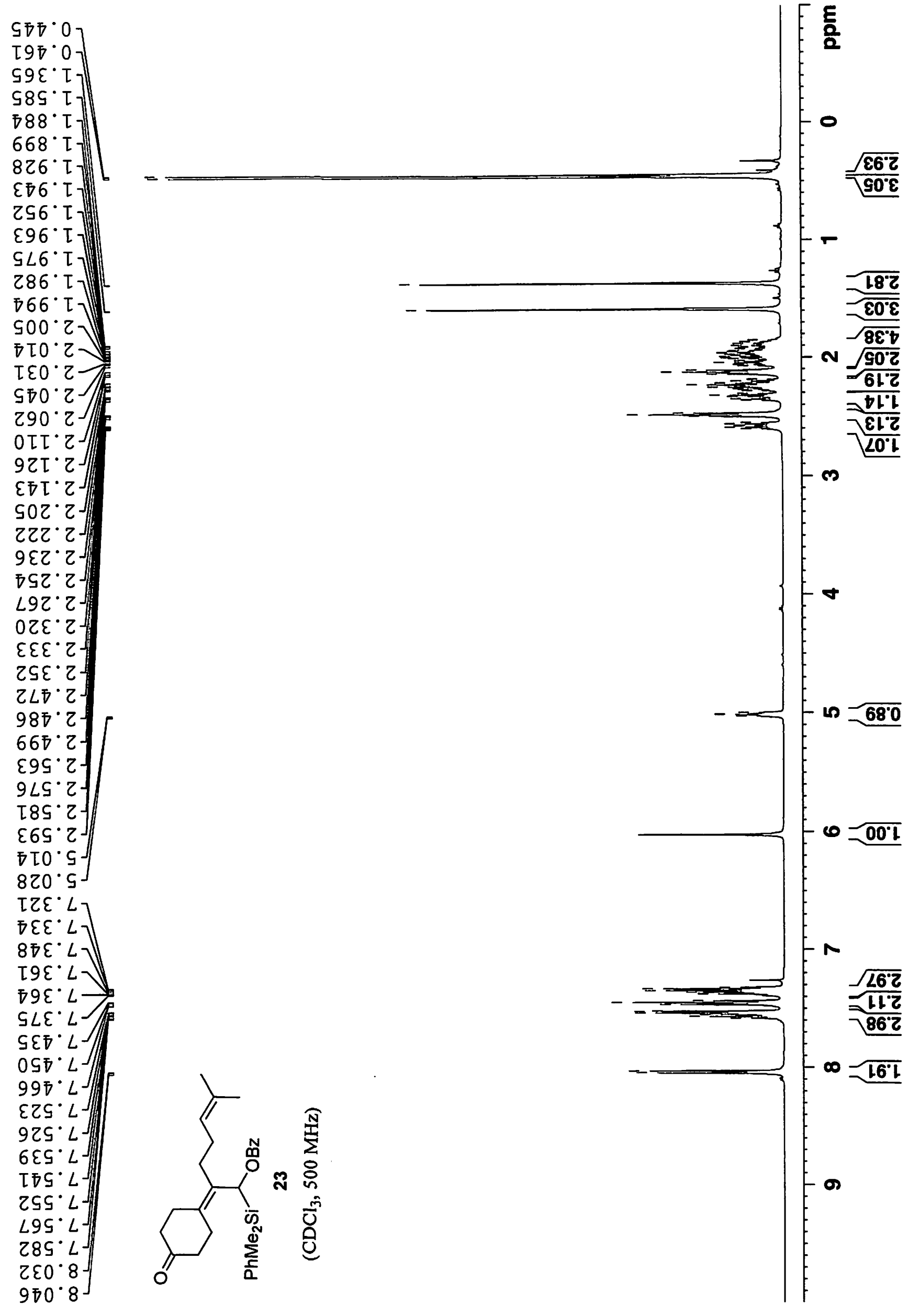


$8 L I^{\circ} \sigma-$

$\angle 5^{\circ} \angle T$ $6 \angle S^{\circ} S Z$
$29 \varepsilon^{\circ} \angle Z$ Sฤ ${ }^{\circ} L Z \backslash$ $\varepsilon 65^{\circ} 8 \mathrm{~T}$ $\varepsilon 98^{\circ} 0 \varepsilon$ $258^{\circ} \cdot 6 \varepsilon$
$\nabla \nabla 2 \cdot 0 \nabla$ ZE9 $O L-$ $\tau \varepsilon \sigma^{\circ} \varepsilon 乙 \tau_{7}$ $\left.\begin{array}{l}6 \varepsilon 8^{\circ} \cdot L Z \tau \\ 0 Z \sigma^{\circ} 8 Z T\end{array}\right]$ $067 \cdot 62[$ $\varepsilon \sigma S^{\circ} 6 Z T$ V $\varepsilon \sigma L \cdot 6 Z I$ $6 S \sigma^{\circ} 0 \varepsilon T$ $S L O^{\circ} \tau \varepsilon \tau$ Ђ $L^{\circ}[\varepsilon[\rfloor$ $8 \nabla 8^{\circ} 乙 \varepsilon[\rfloor$ $\varepsilon L 0^{\circ} \nabla \varepsilon[J$ $\varepsilon \nabla L \cdot \varsigma \varepsilon[]$

$826 \cdot 99 I-$

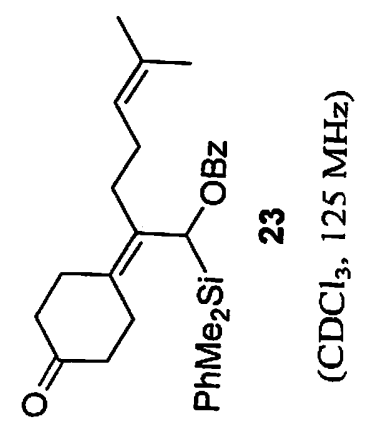

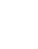

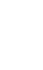

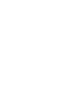

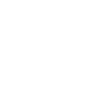

章 $-\frac{E}{\circ}$

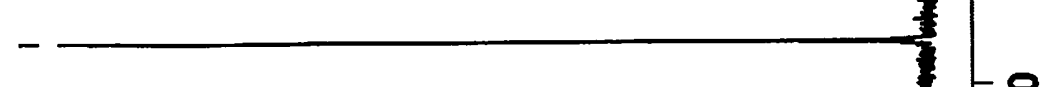



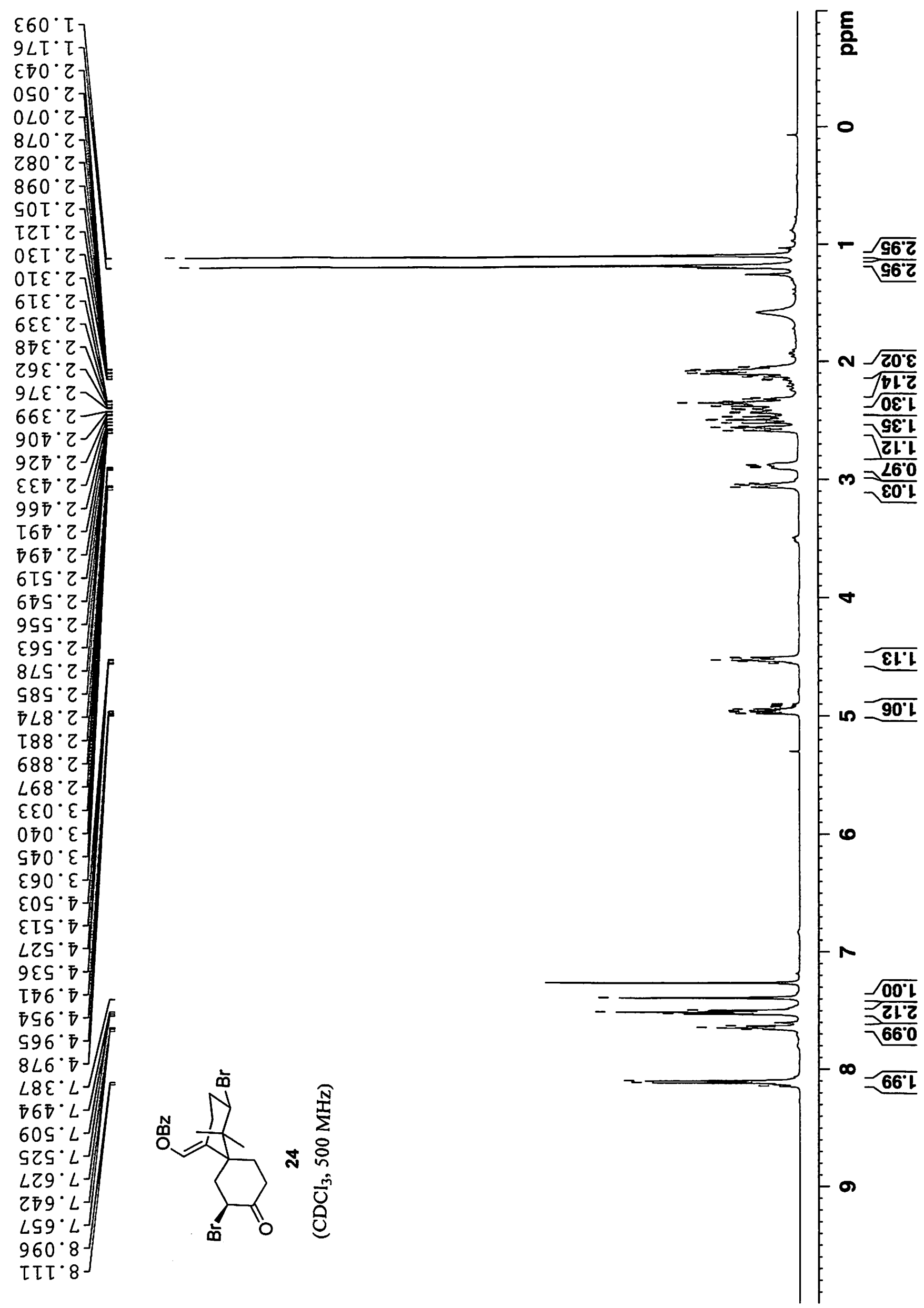


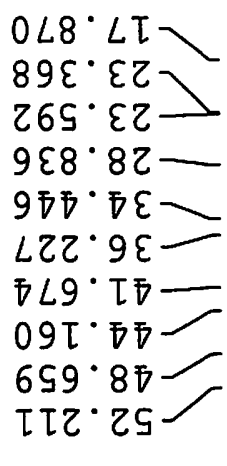

$084 \cdot 29$

ธぇて $\varepsilon 乙 \tau$ $60 L \cdot 82 \tau$

$97 L \cdot 8 Z T$

โह $\sigma^{\circ} 6 \tau \tau-$

$\varepsilon 66^{\circ} \mathrm{z} \tau$

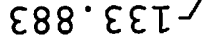

Ð $L \cdot \varepsilon 9 \tau-$

$\angle I 8^{\circ} 002-$

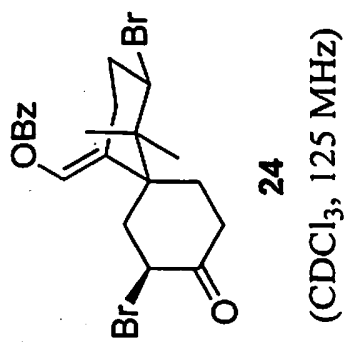

$j\left[\begin{array}{l}E \\ \bar{\alpha}\end{array}\right.$

0

오

웅

8

오

옹

8

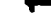

요

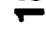

옹

ิㅗ 

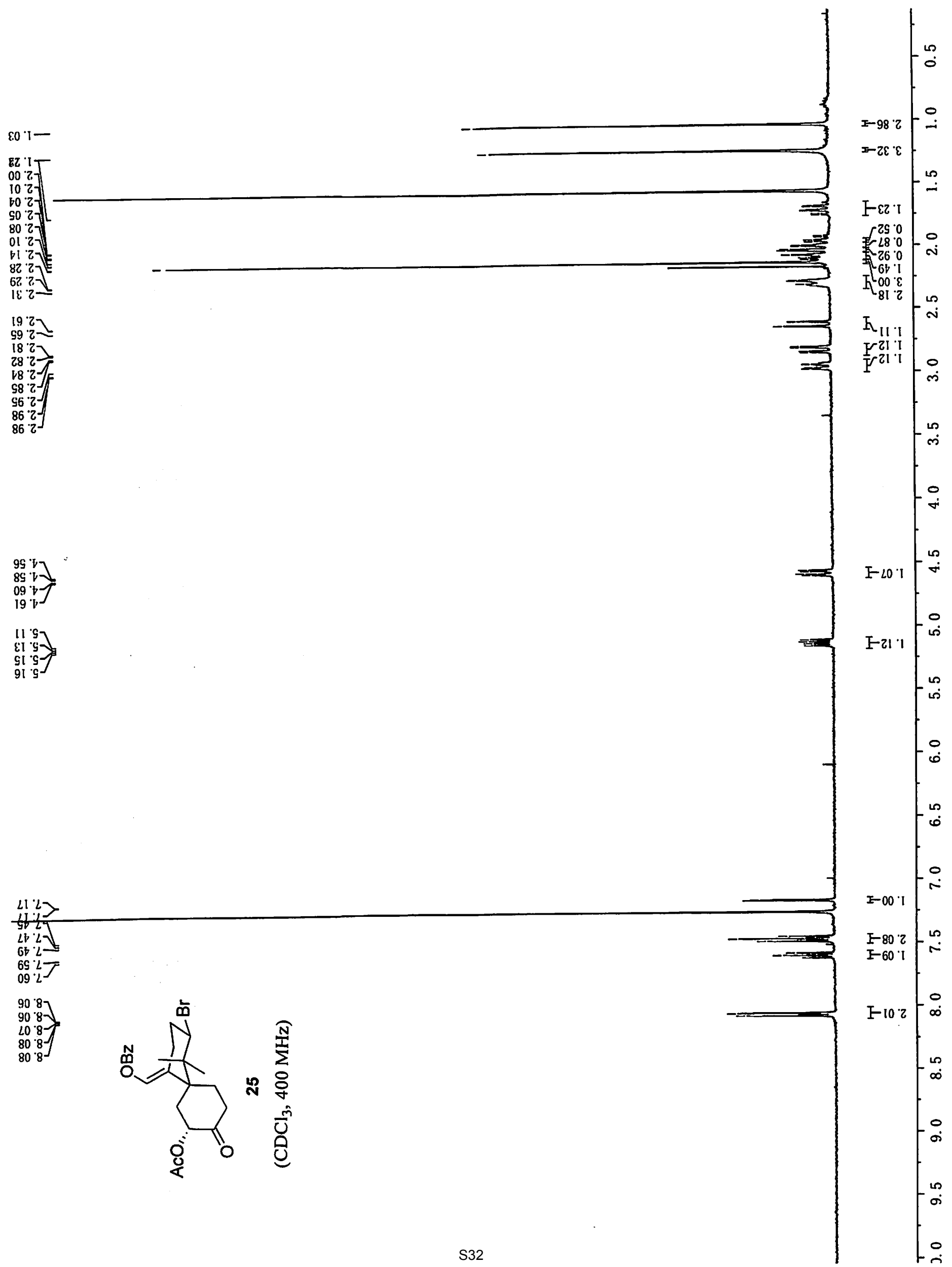

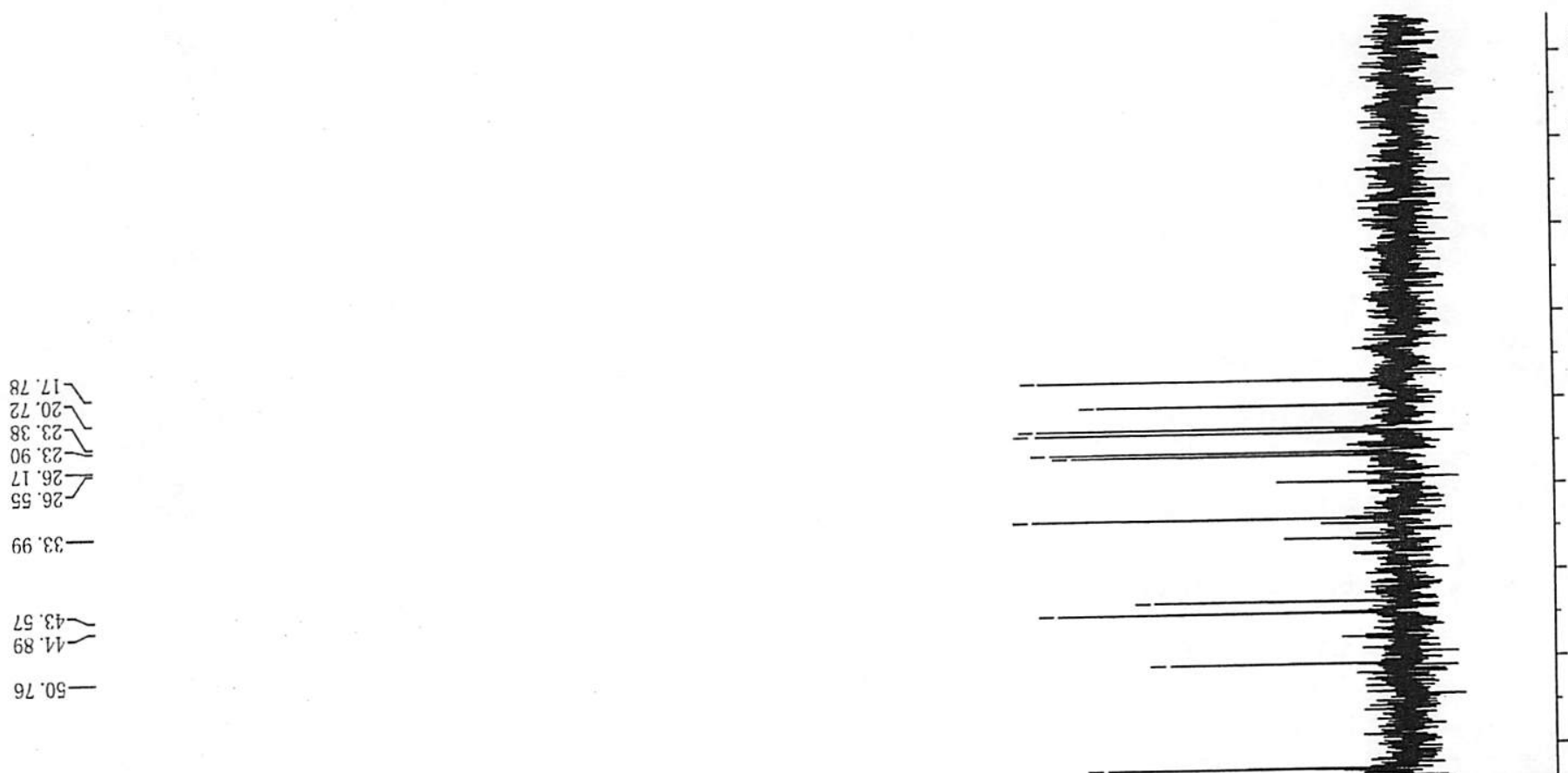

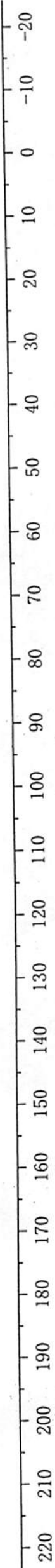




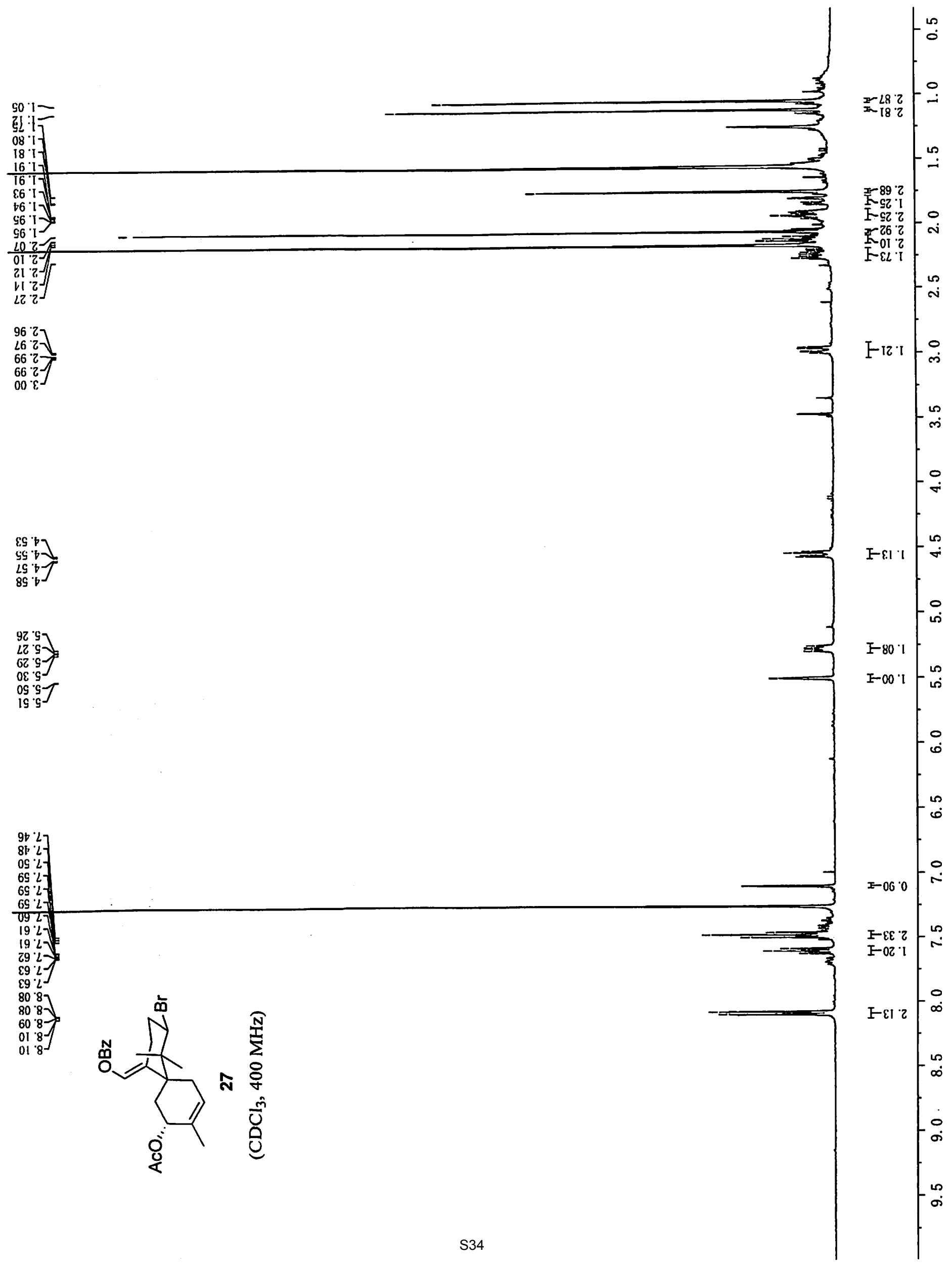



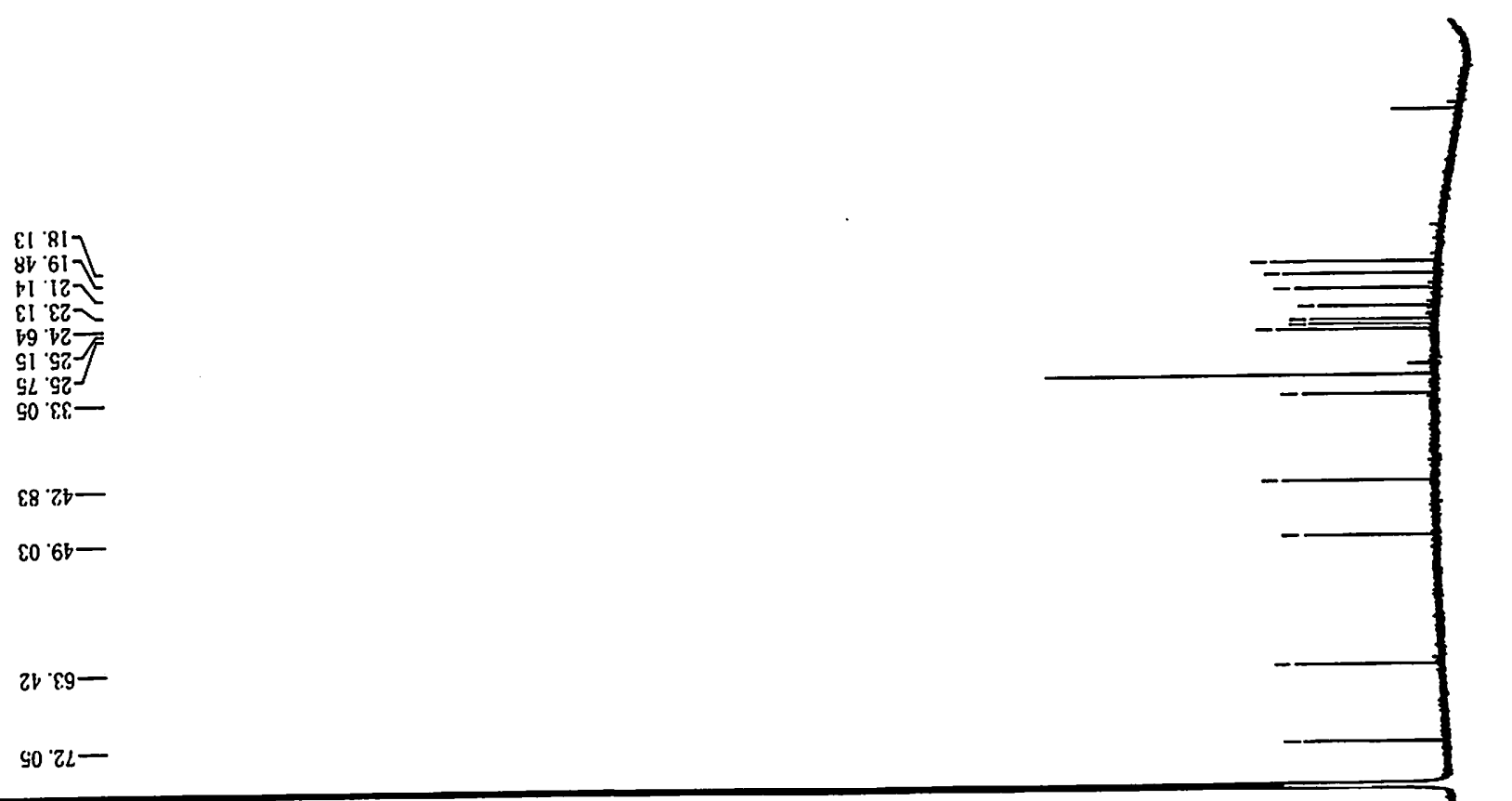

S0 $2 L-$

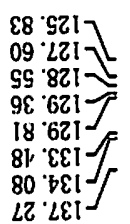

$89^{\circ} \mathrm{c9l}-$
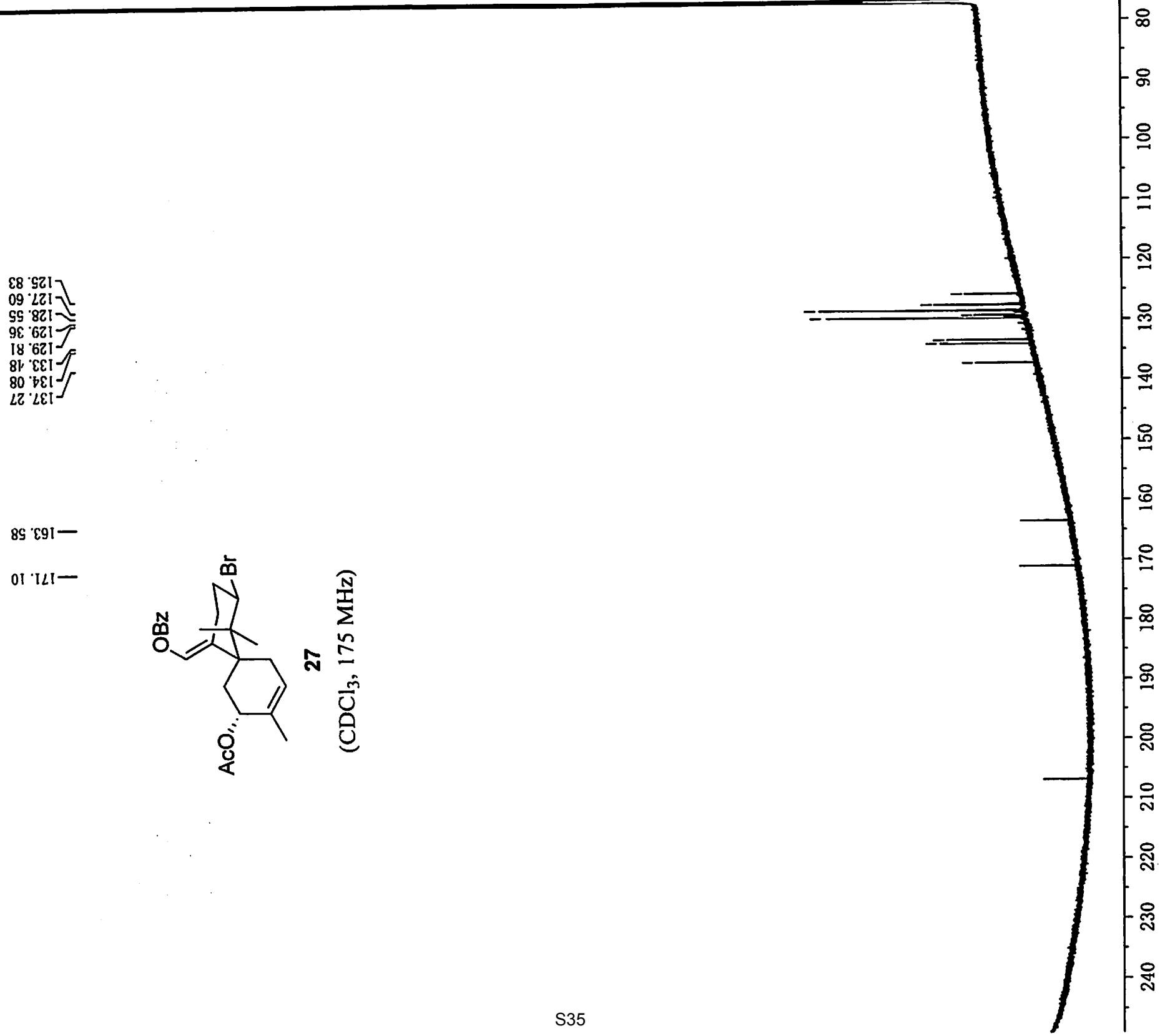


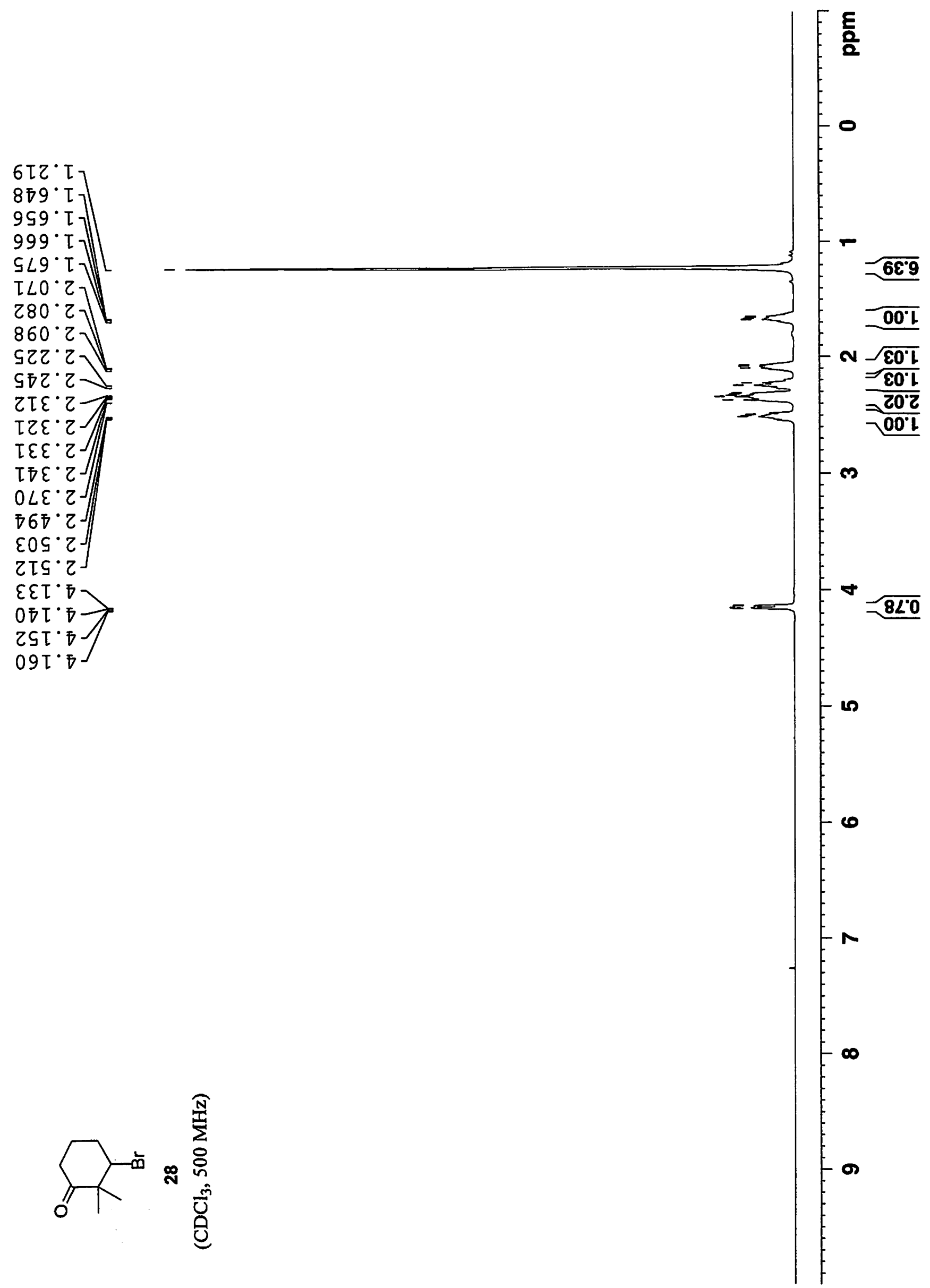




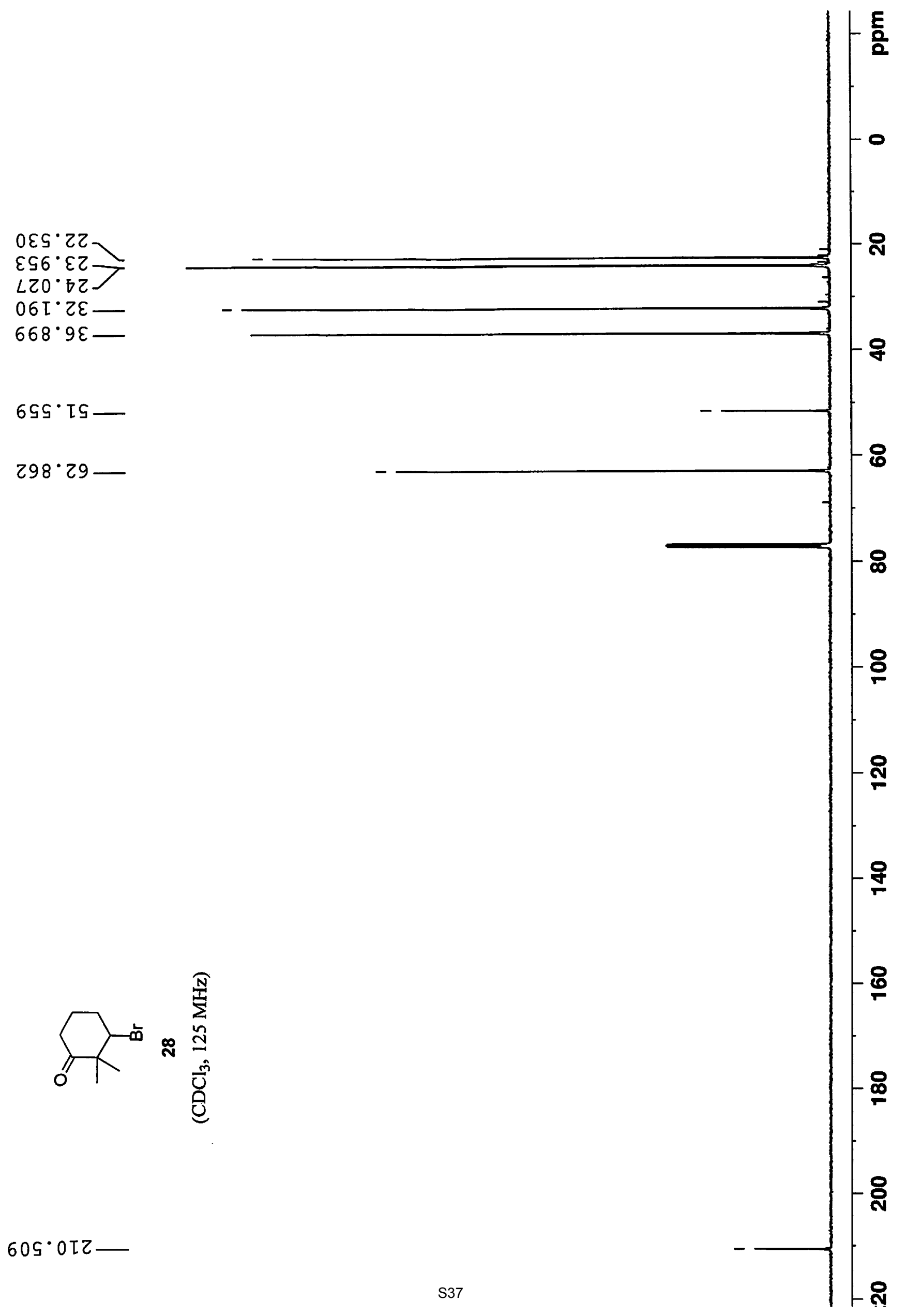




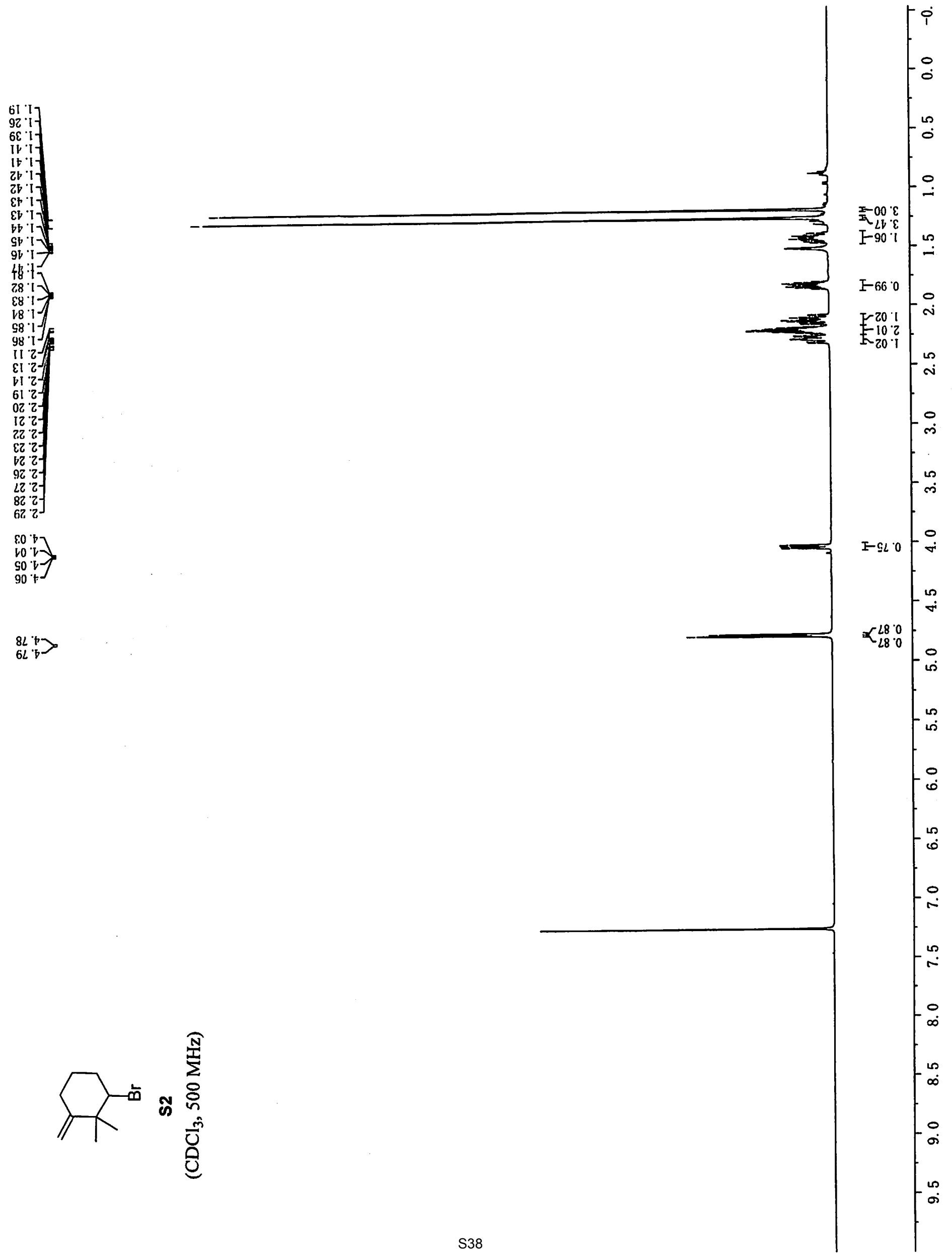




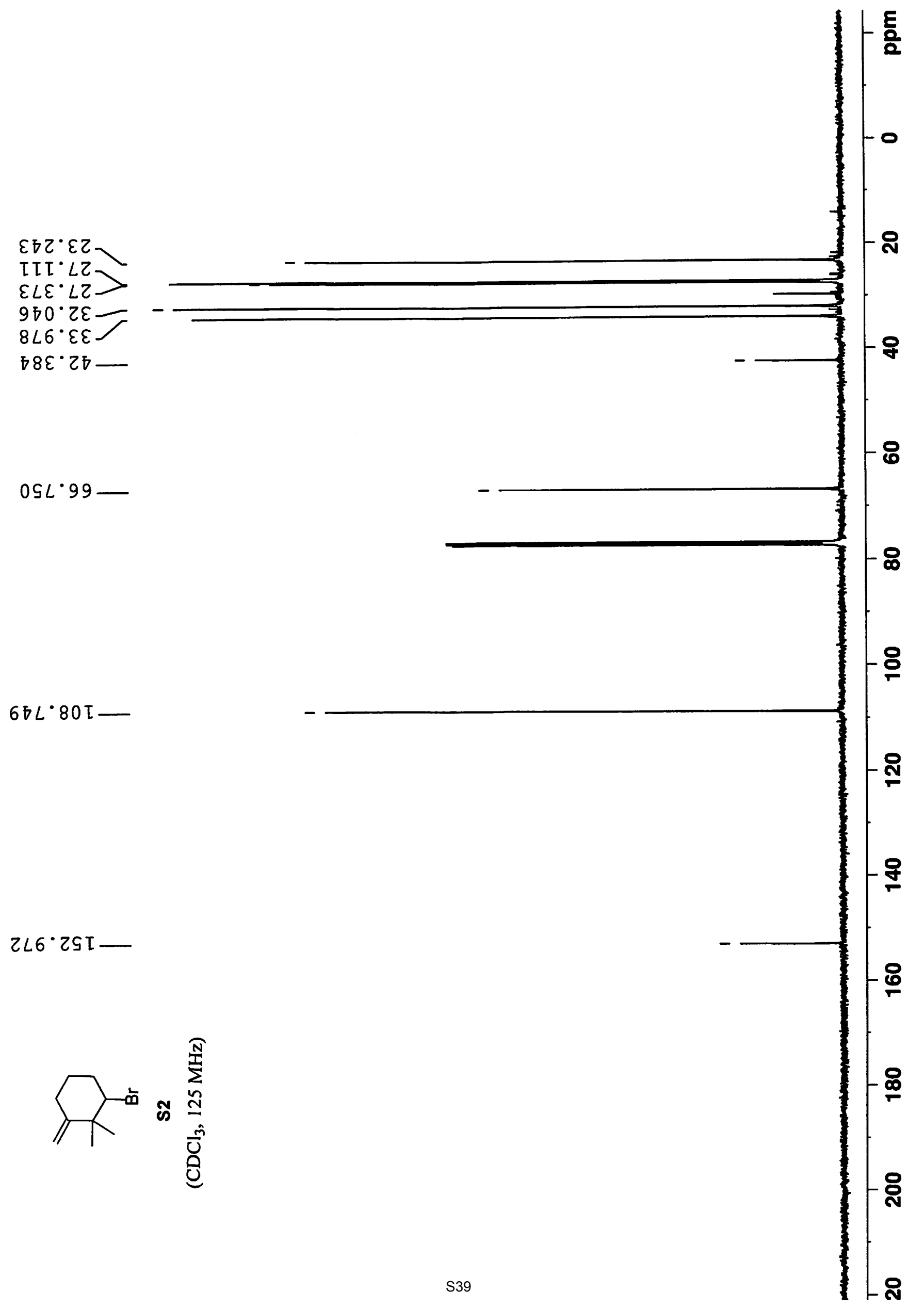




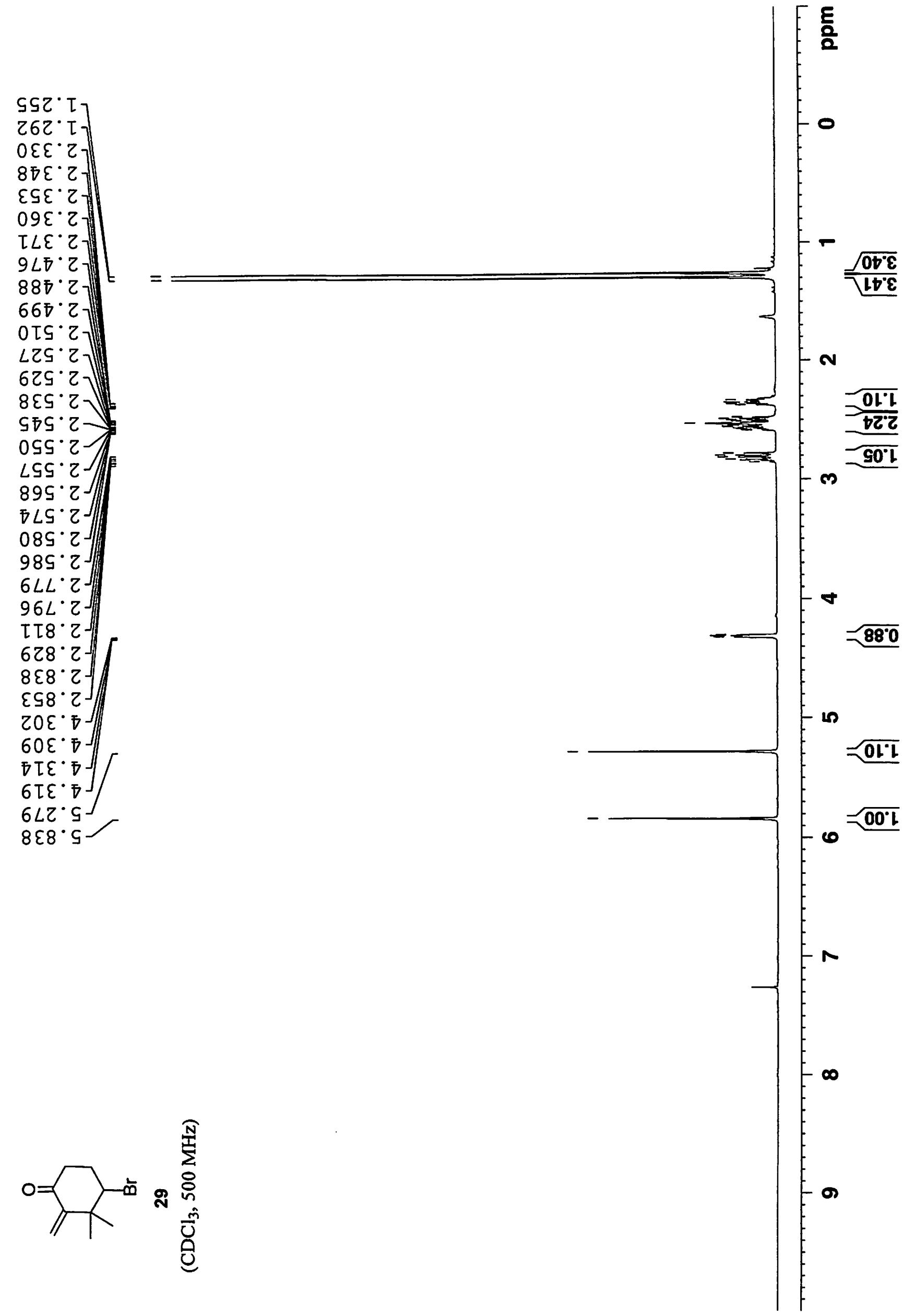




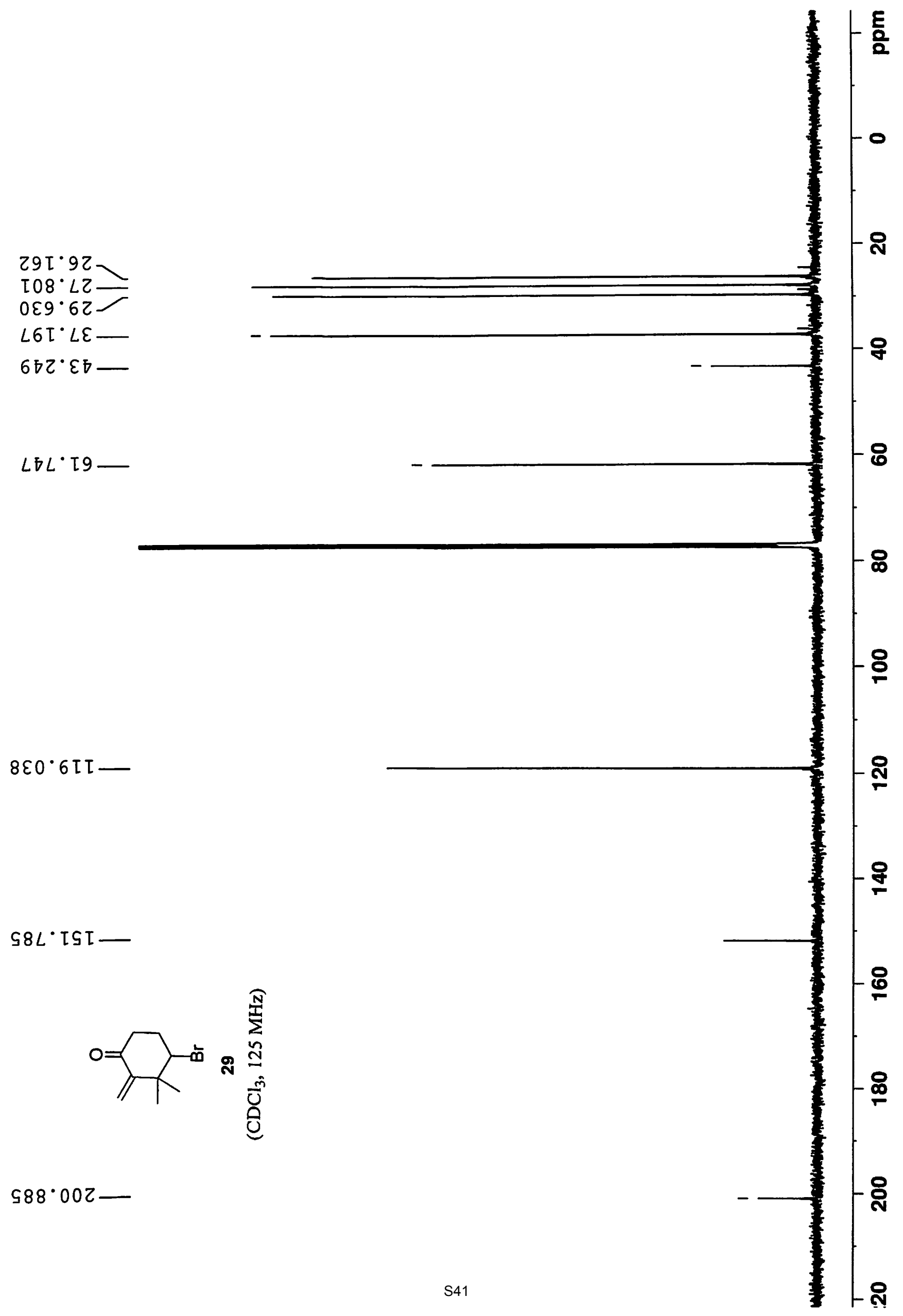




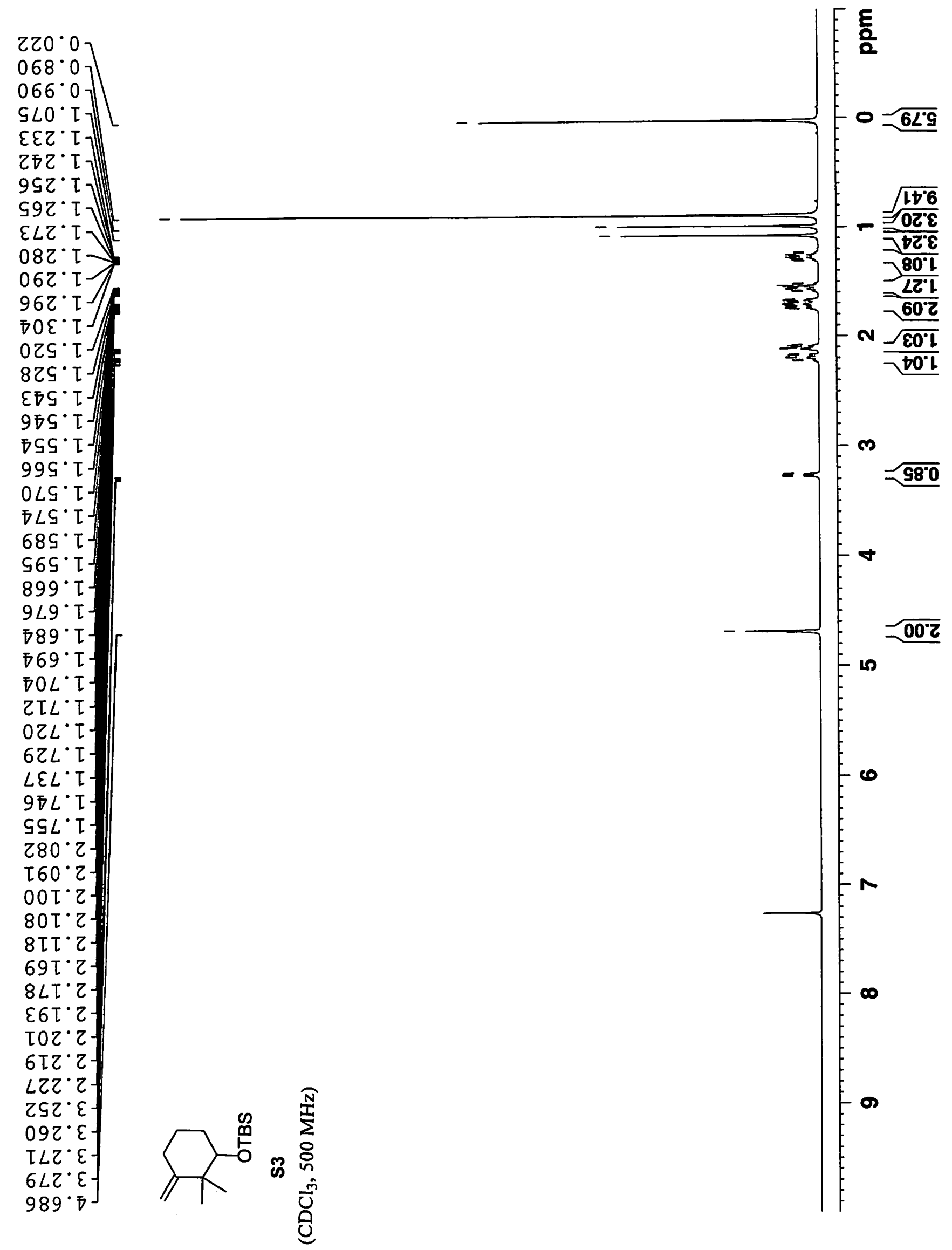




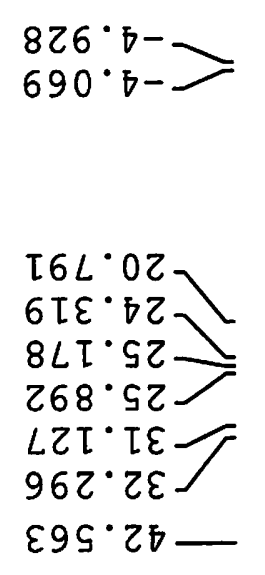

$256^{\circ} \mathrm{LL}$

$280^{\circ} \mathrm{LOL}-$

997.SSI -

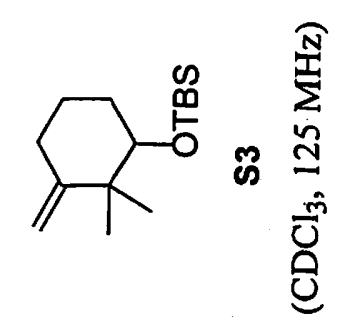

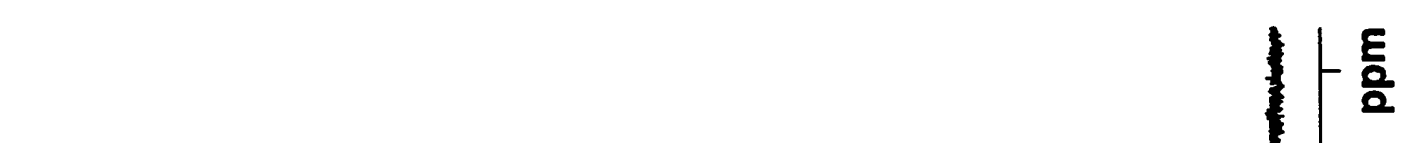

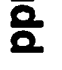

- กิ

8

으

ฐิ

웅

$r$

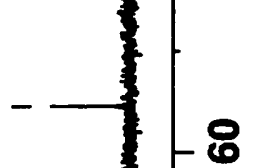

웅

$\underset{\infty}{\mathbf{\infty}}$

- 유

- ָำ 


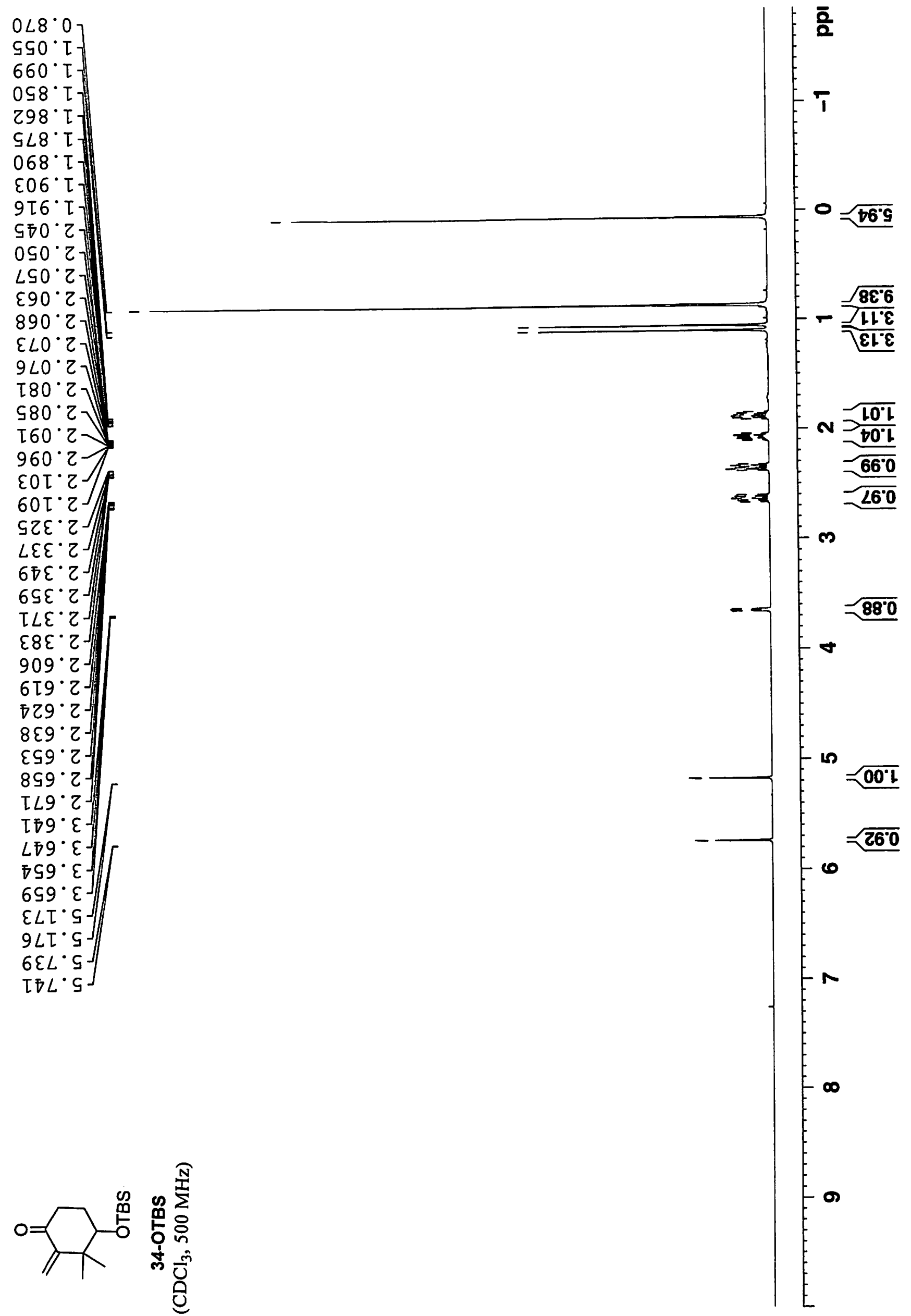


$266^{\circ} \nabla-$

จโE'จ->

โS $9^{\circ} \varepsilon Z$

$8 \nabla L \cdot S Z$

ธ28.9Z

ธ95 $L 2$

$289^{\circ} \varsigma \varepsilon$

$\varepsilon L 0^{\circ} \varepsilon \sigma-$

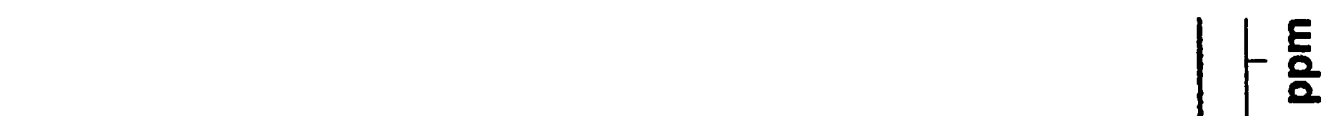

$S 90^{\circ} S L$
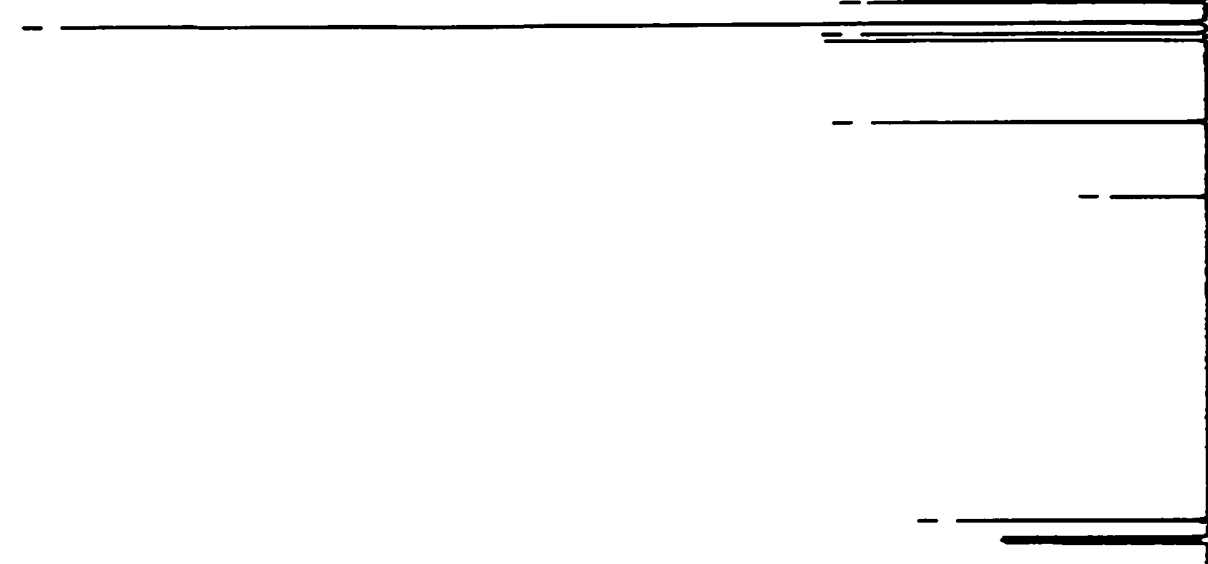

Q

8

$686^{\circ} L I L$

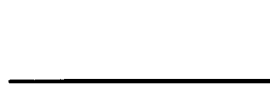

$\varepsilon 0 L^{\circ} \varepsilon S I-$

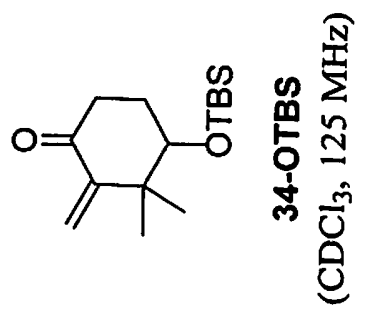

$L L 8^{\circ} 202$ 


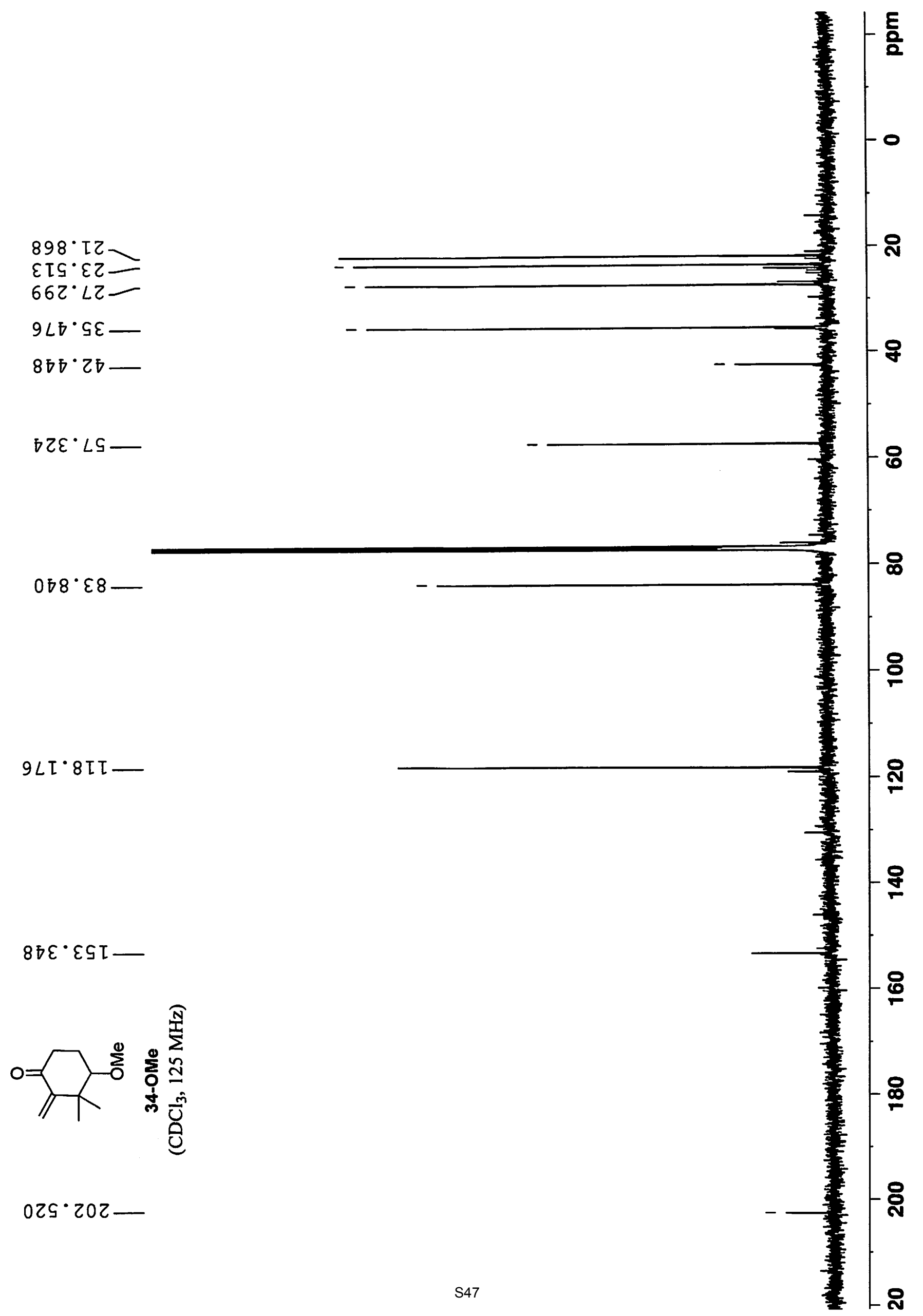




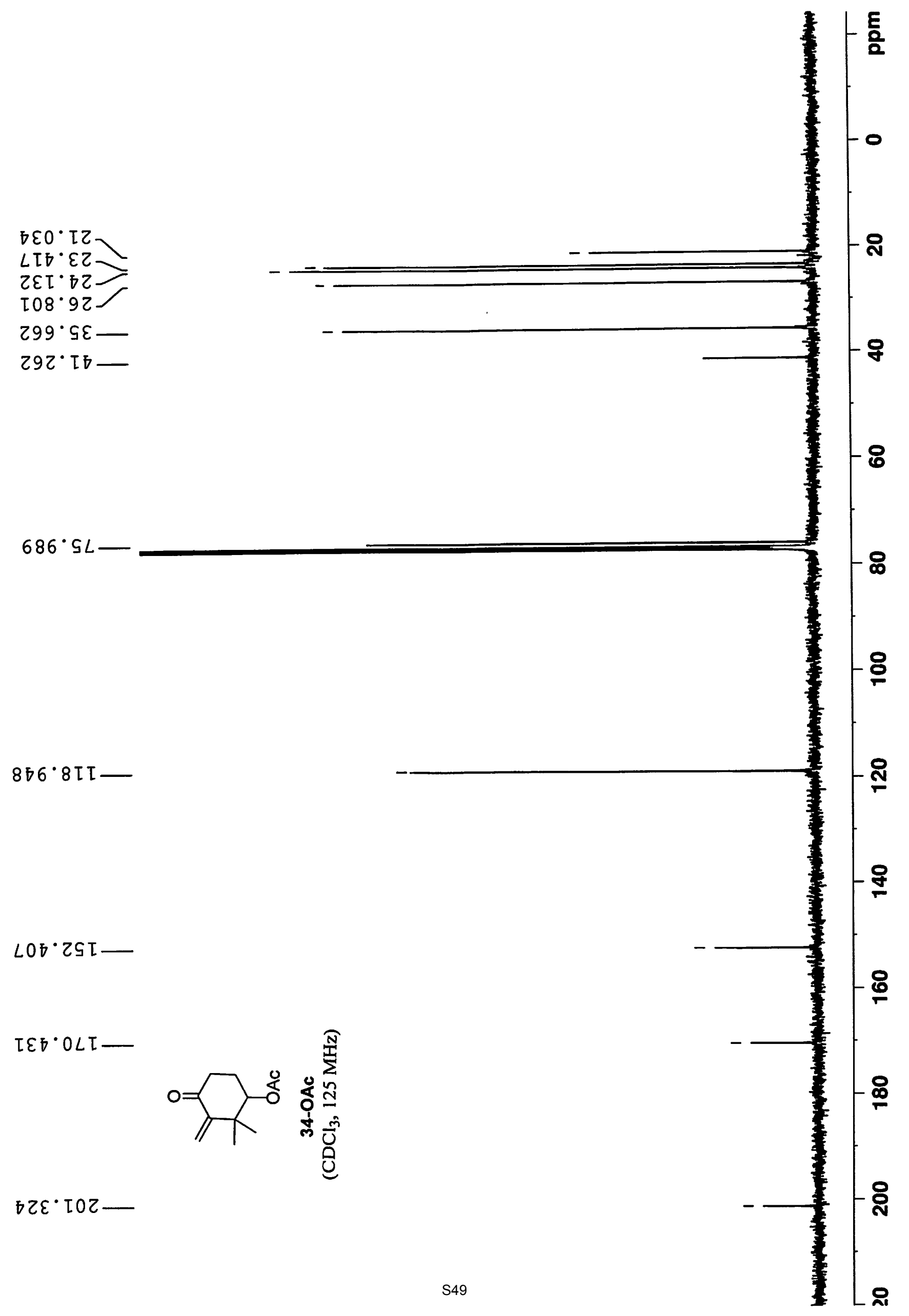



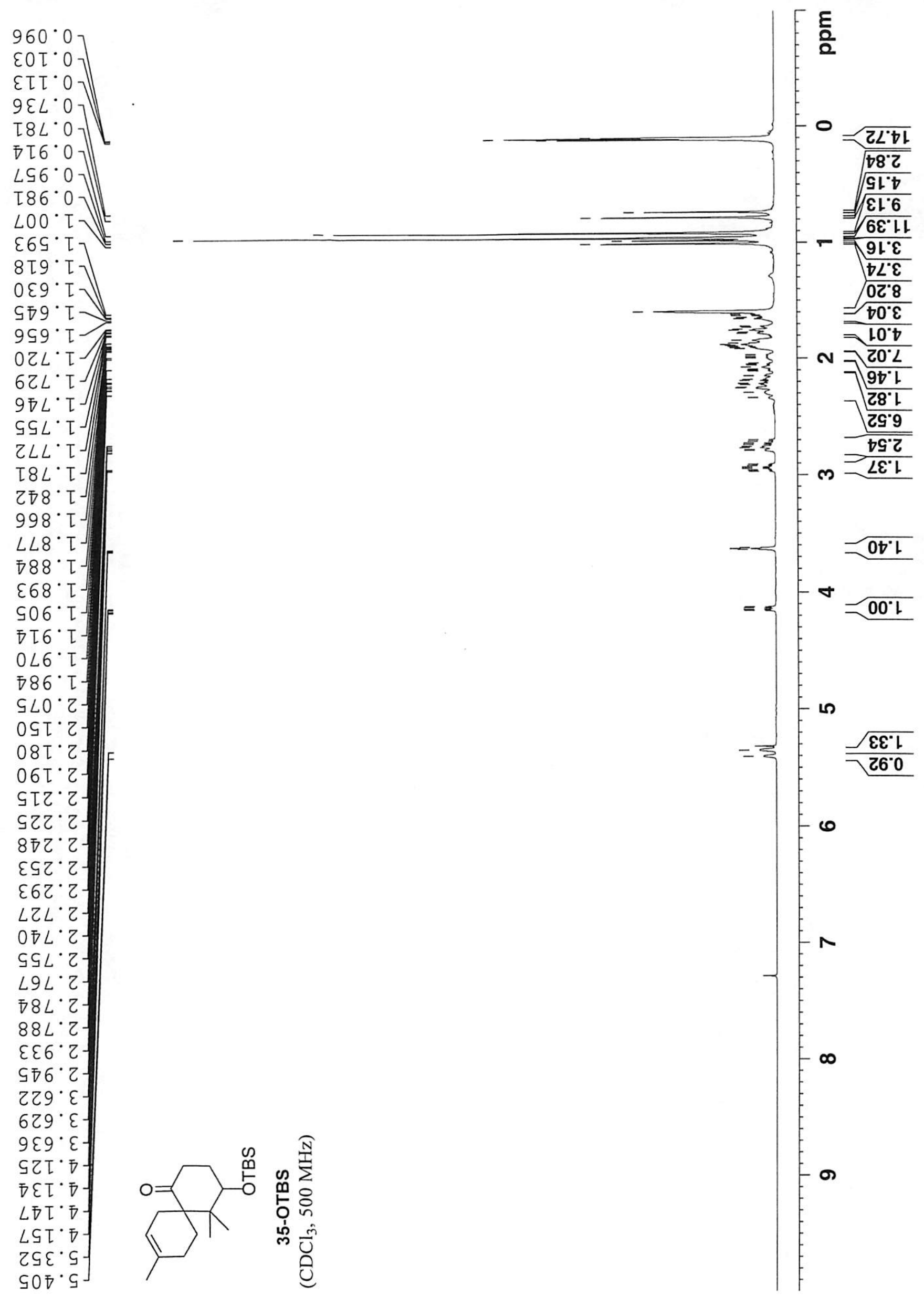


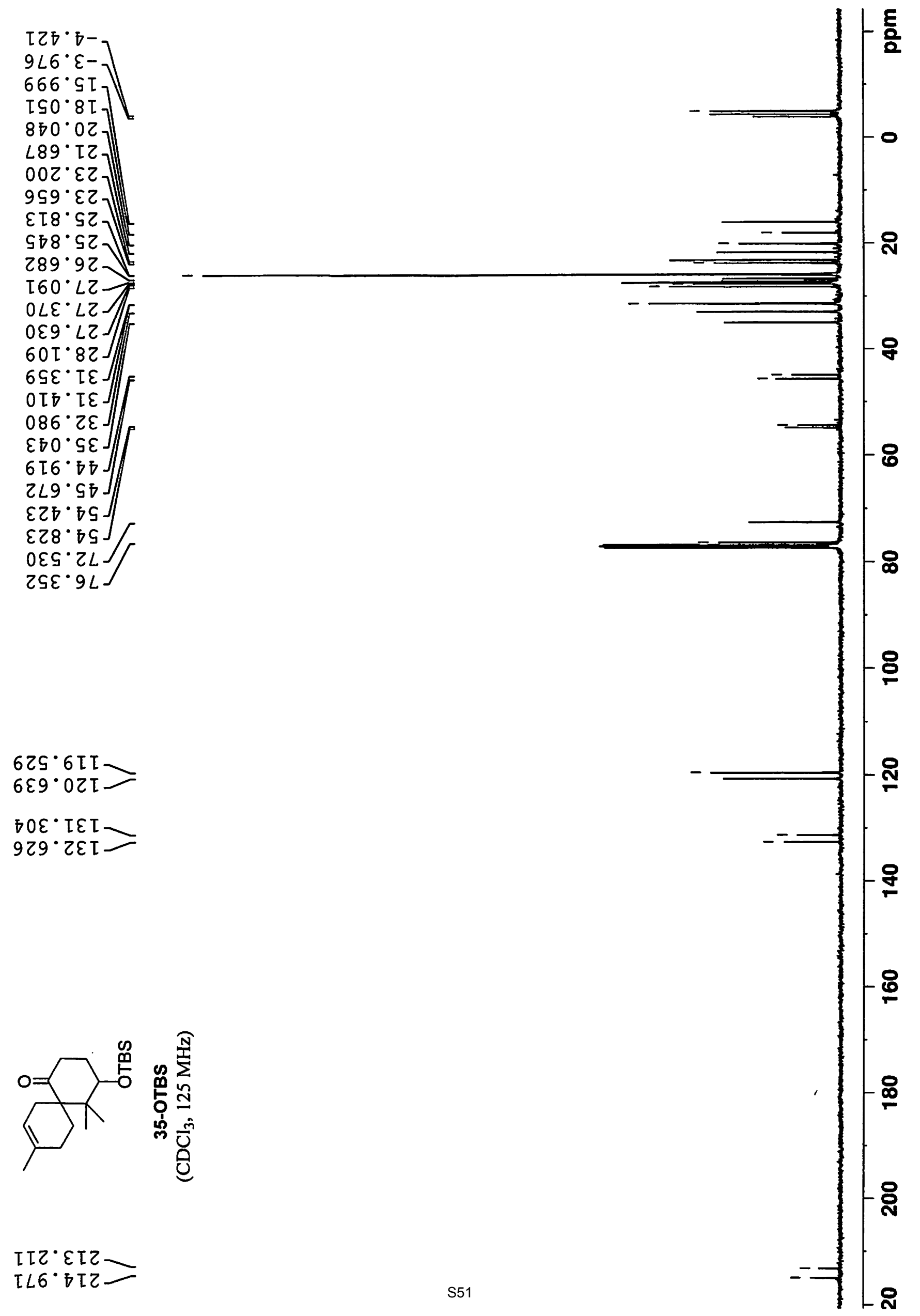




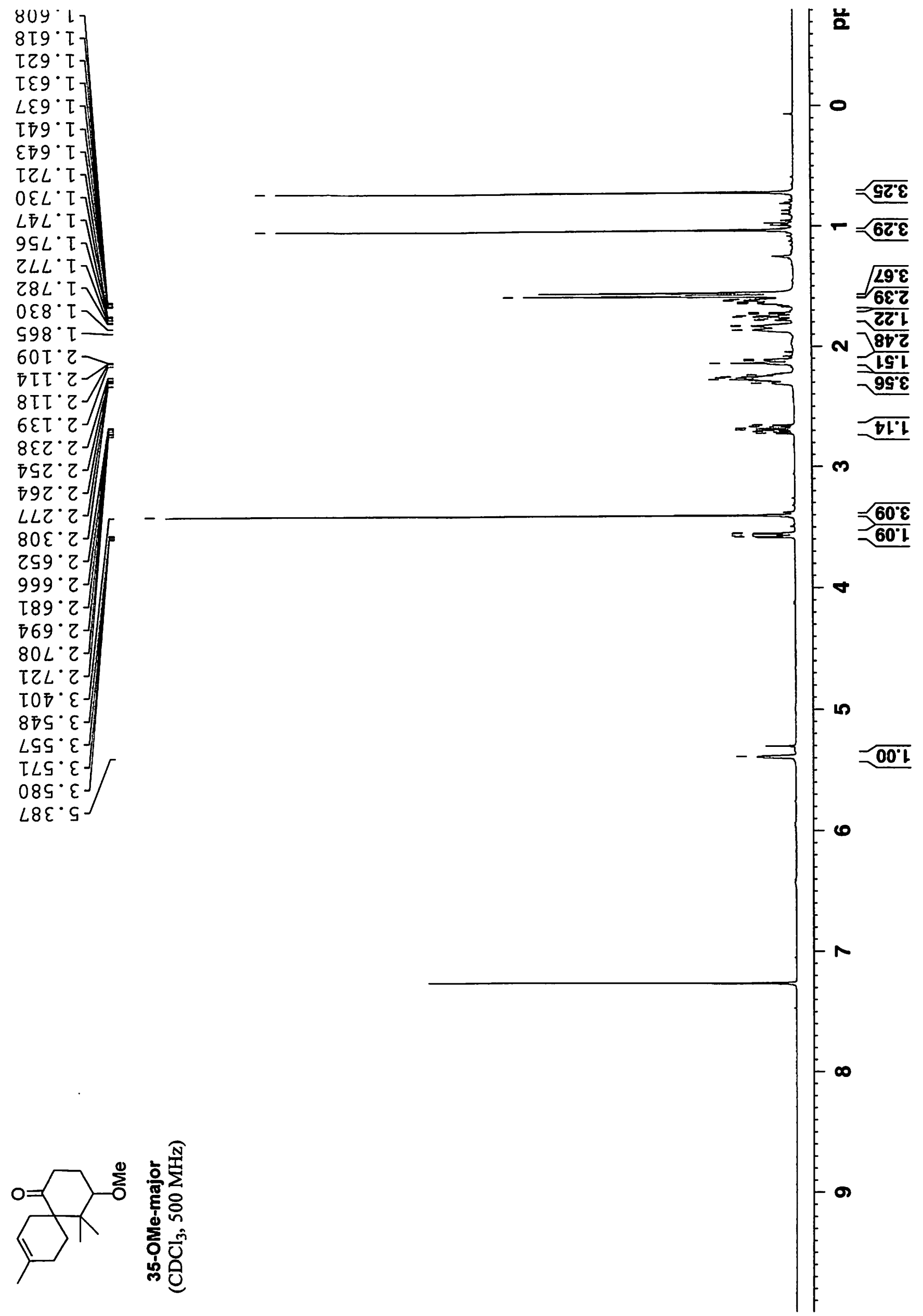



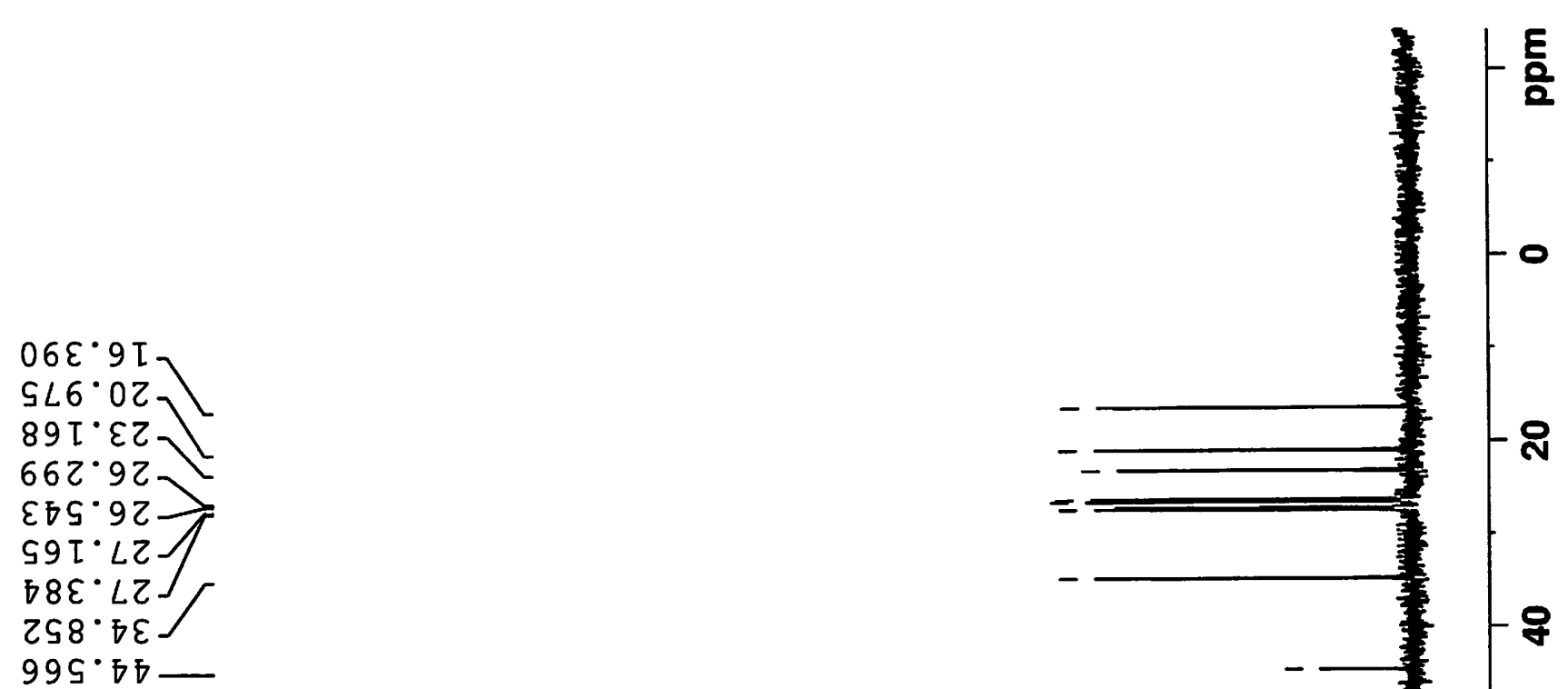

$6 \varepsilon \sigma^{\circ} \sigma S-$

$086^{\circ} \mathrm{LS}$

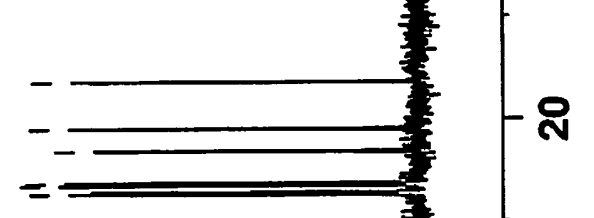

$809^{\circ} 02 \mathrm{I}$

$9 \varepsilon \varepsilon \cdot \tau \varepsilon \tau-$
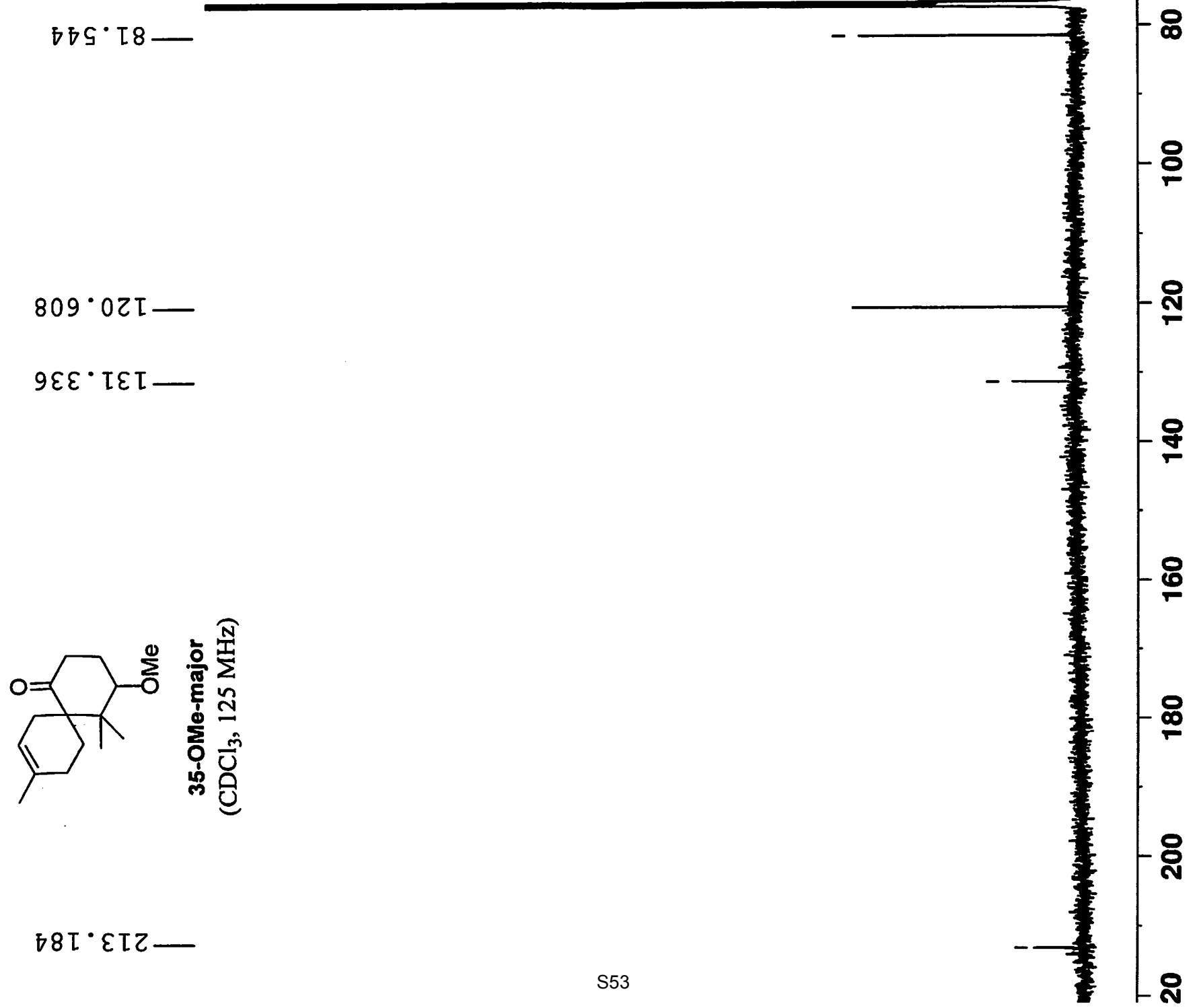

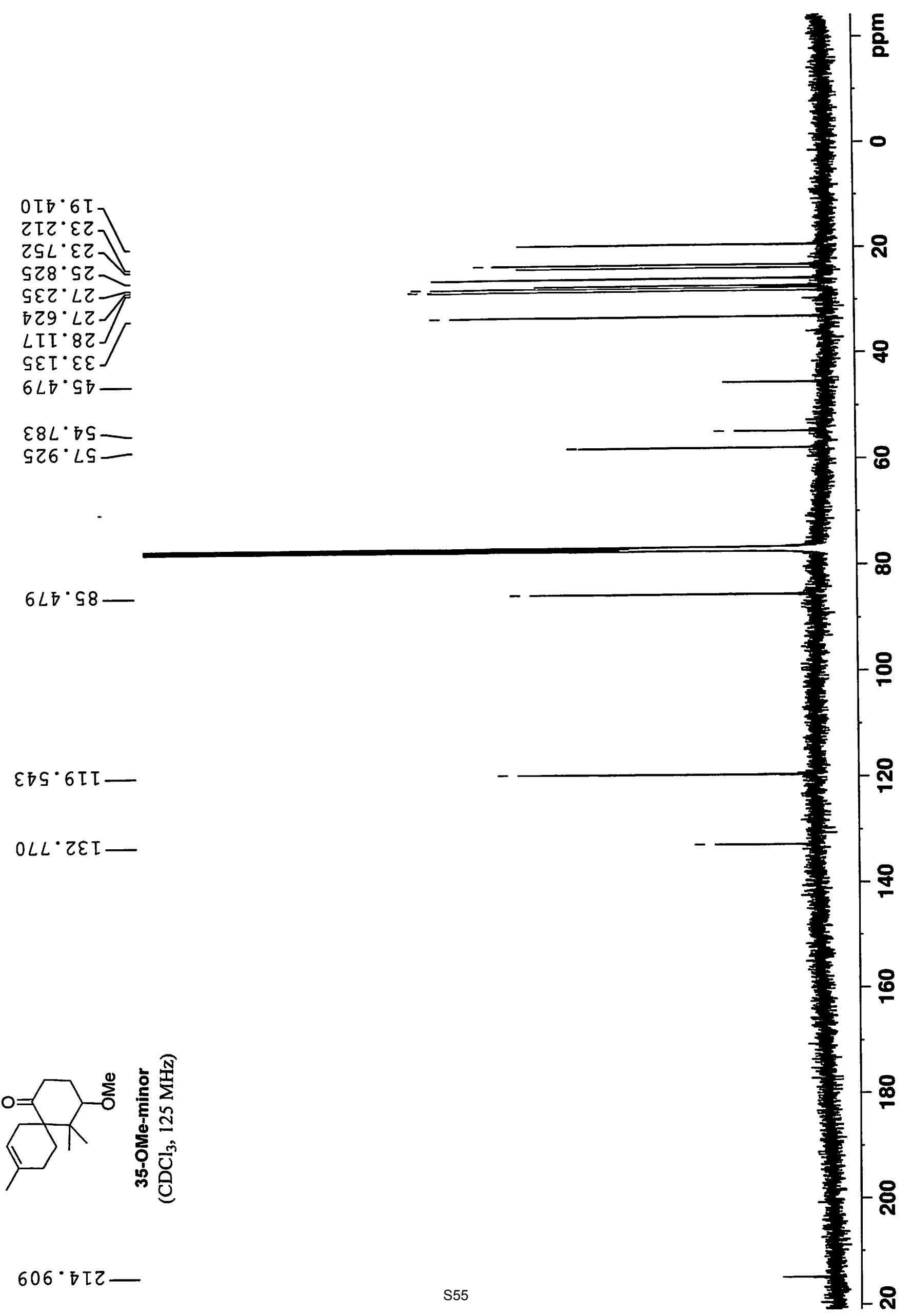


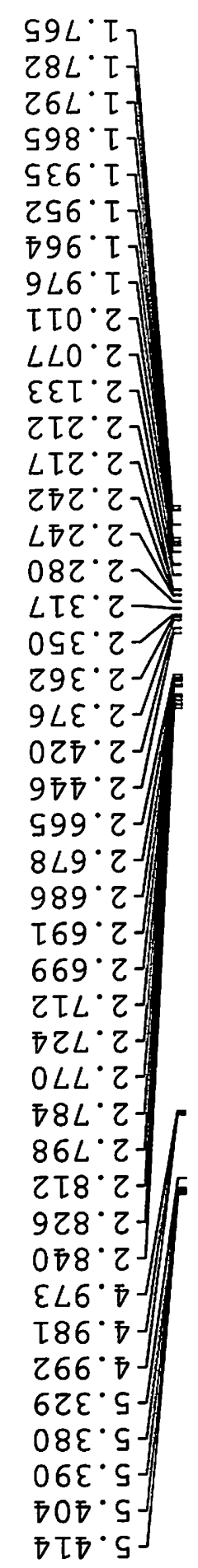

흘

$26 \mathrm{~L}^{\circ} \mathrm{T}$

$\varsigma 98^{\circ} \tau$

ง $6 \sigma^{\circ}$

256 I

$\checkmark 96^{\circ} \mathrm{I}$

$9 L 6^{\circ} \mathrm{L}$

[IO $Z$ ]

$\varepsilon \varepsilon \tau \cdot z]$

乙โ乙 ${ }^{\circ}$

乙戸て

$087^{\circ} z$

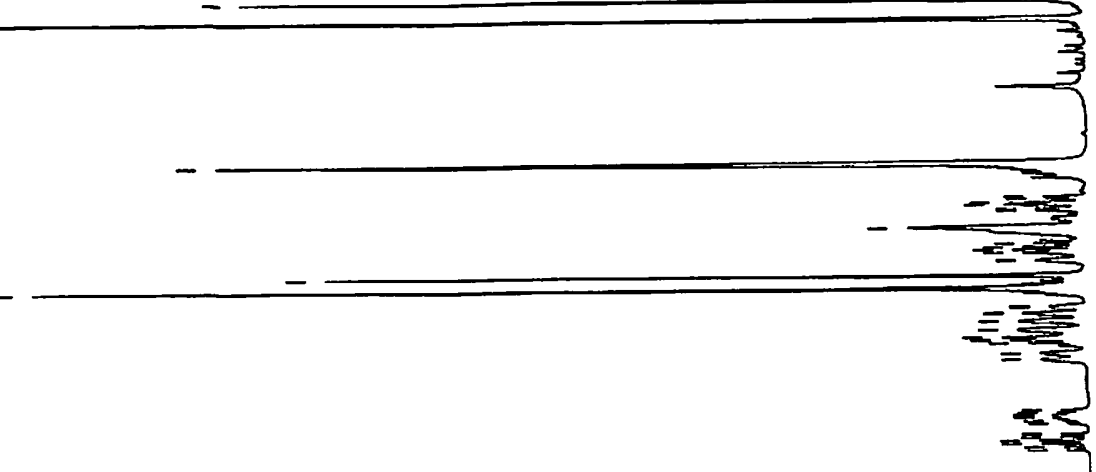

-

$\mathbf{N}$

$9 L^{\prime} \varepsilon$

LO9

$=\sqrt{\frac{\sqrt{\frac{D L Z}{D Z L}}}{\sqrt{0.1 L}}}$

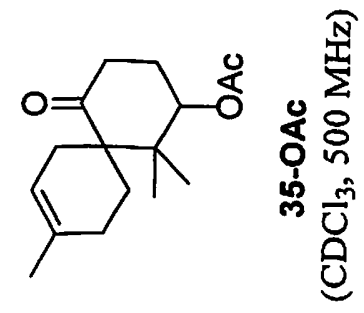



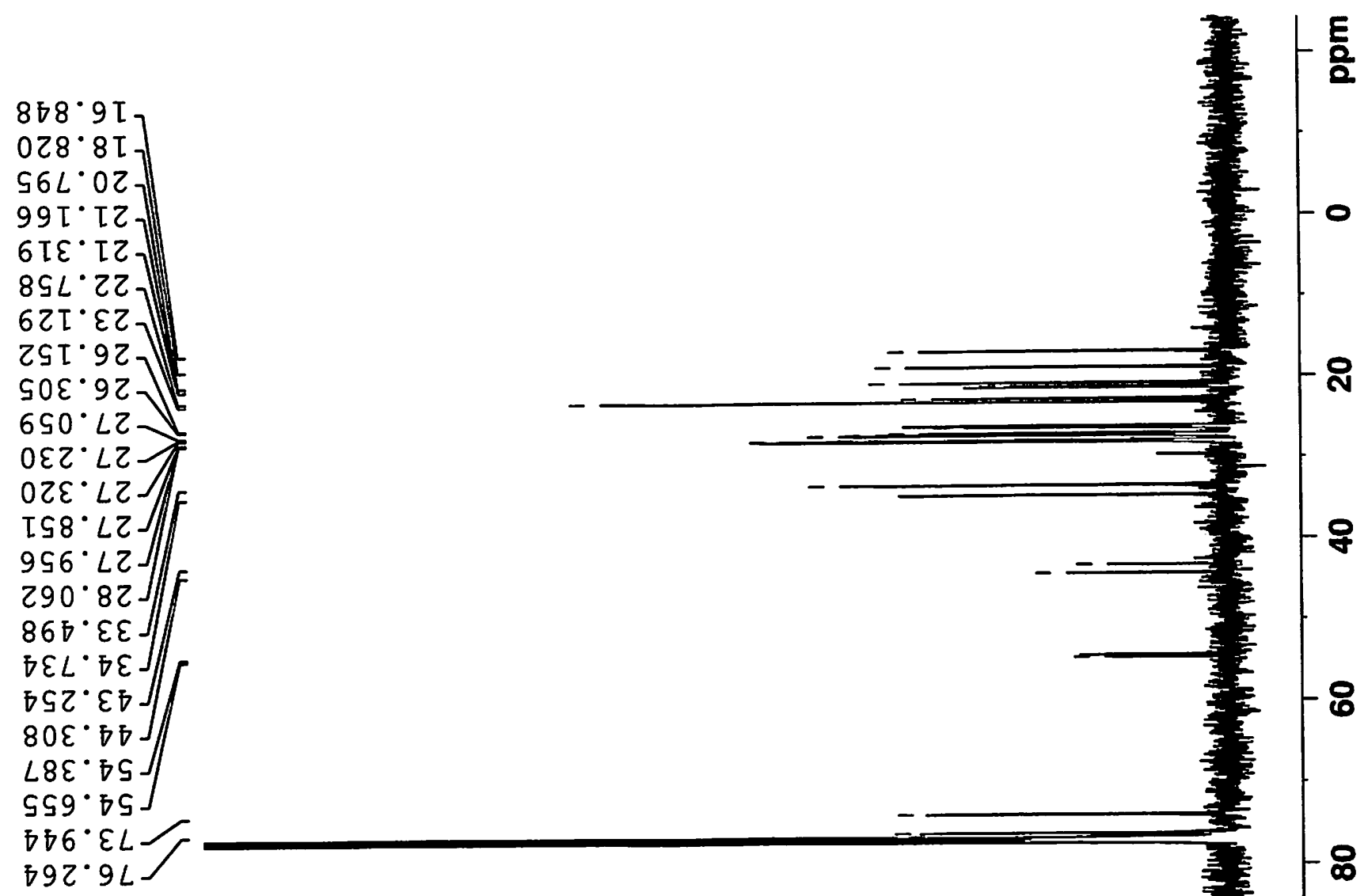

$028 \cdot 8 \mathrm{~T}$

$56 \mathrm{~L}^{\circ} 0 \mathrm{Z}$

$99 I^{\circ}[Z]$

$8 S L \cdot 2 Z$

$6 乙 \tau \cdot \varepsilon Z$ ?

ZSI.9Z

$650^{\circ} \mathrm{LZ}$

$0 \varepsilon \mathcal{O}^{\circ}\llcorner Z$

$0 Z \varepsilon^{\circ}\llcorner Z$

โS $8^{\circ}$ LZ J

$996^{\circ} L Z$

$\left.290^{\circ} 82\right]$

$86 \sigma^{\circ} \varepsilon \varepsilon-$

$\nabla \varepsilon L \cdot \nabla \varepsilon]$

$ธ S \mathcal{C}^{\circ} \varepsilon \delta$

L8E $\nabla S\rfloor$

S59. $5 \subseteq\rfloor$

$\nabla 9 Z^{\circ} 9 L$

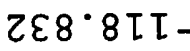

$822 \cdot 02 \mathrm{~T}$

$\varepsilon 9 \sigma^{\circ} \tau \varepsilon \tau$

$\varepsilon \emptyset \tau \cdot \varepsilon \varepsilon \tau$

$T \angle E^{\circ} O L T$

OL9.OLI $>$

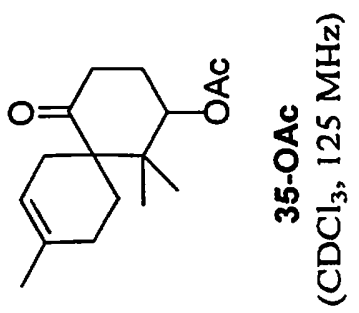




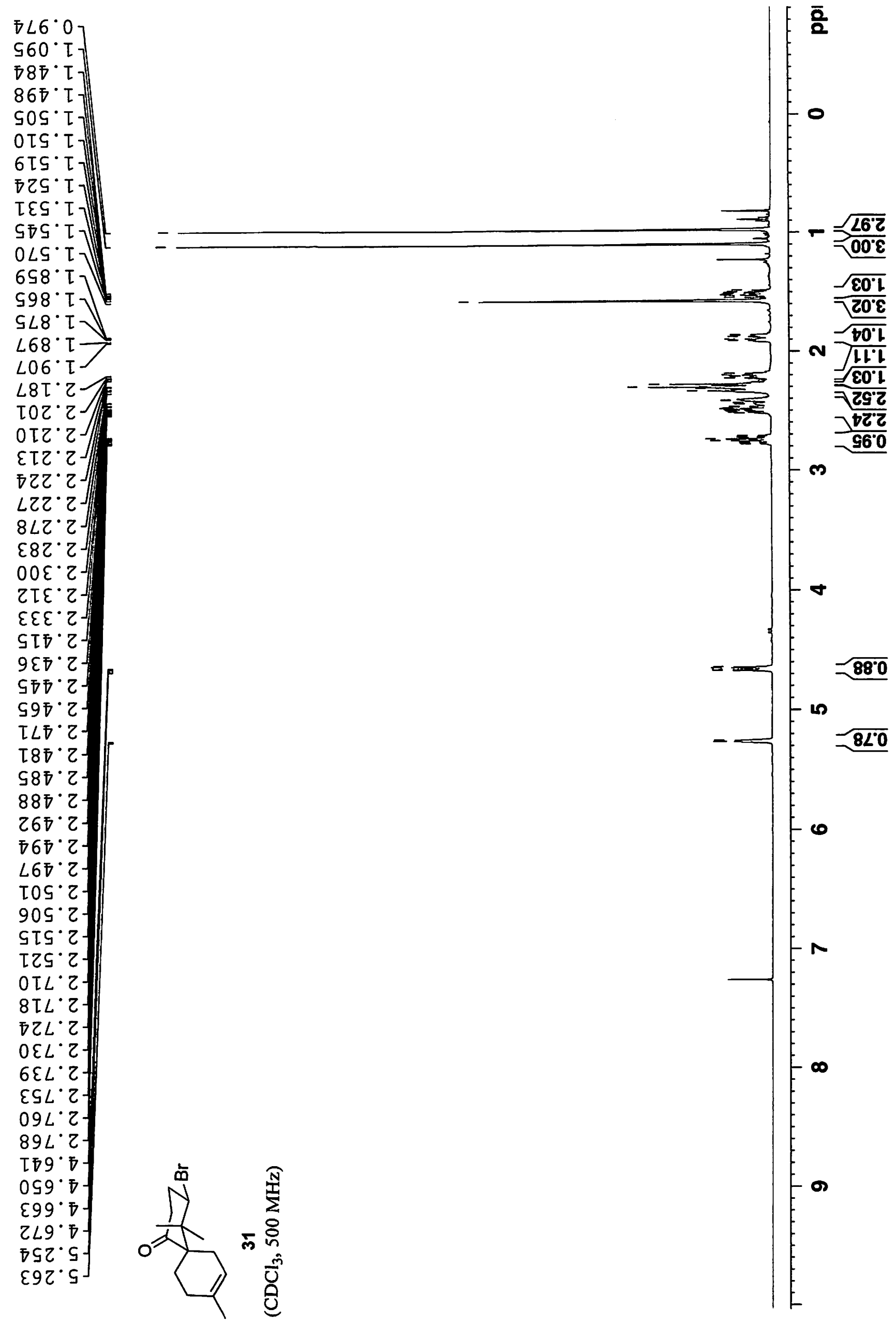



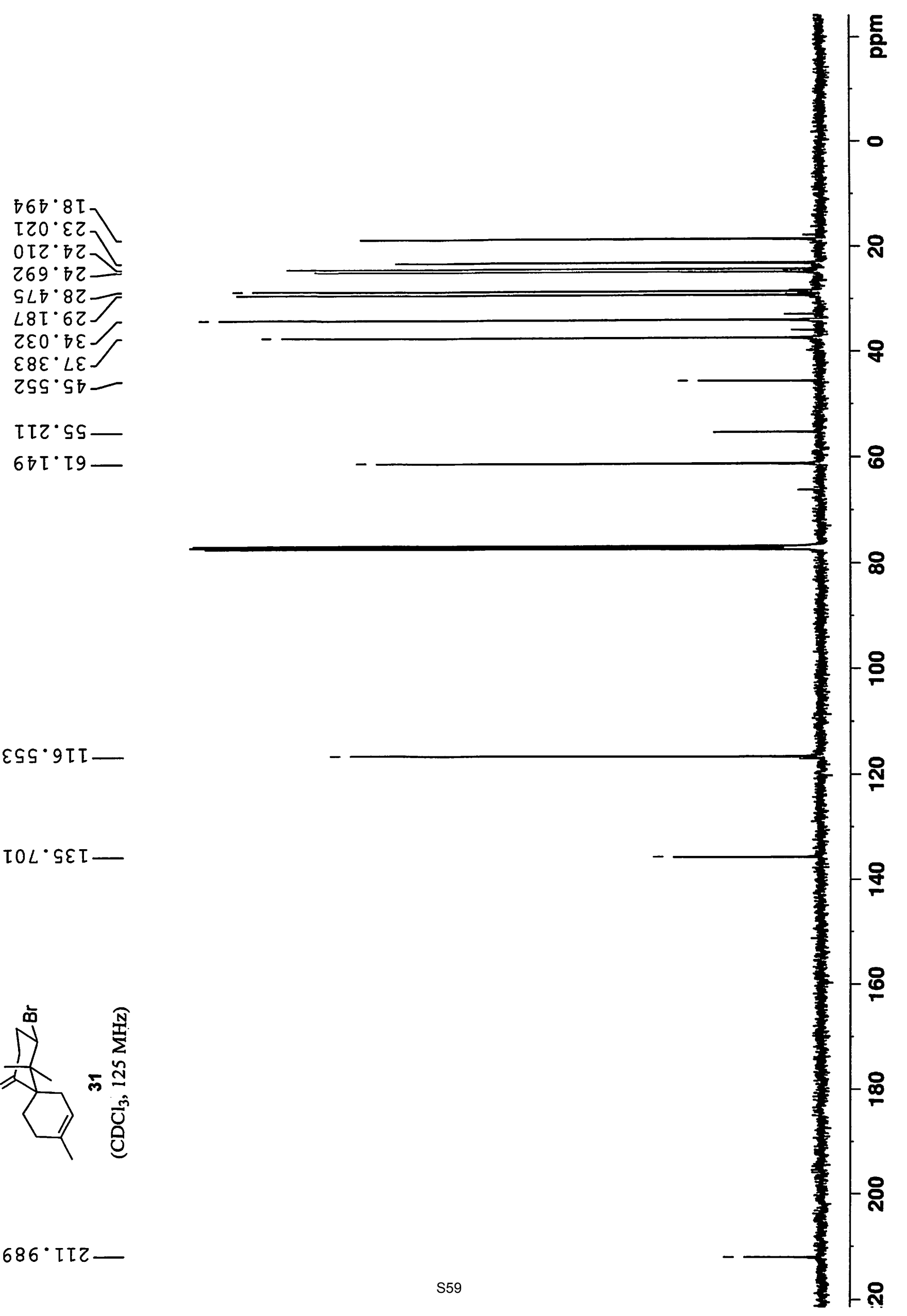


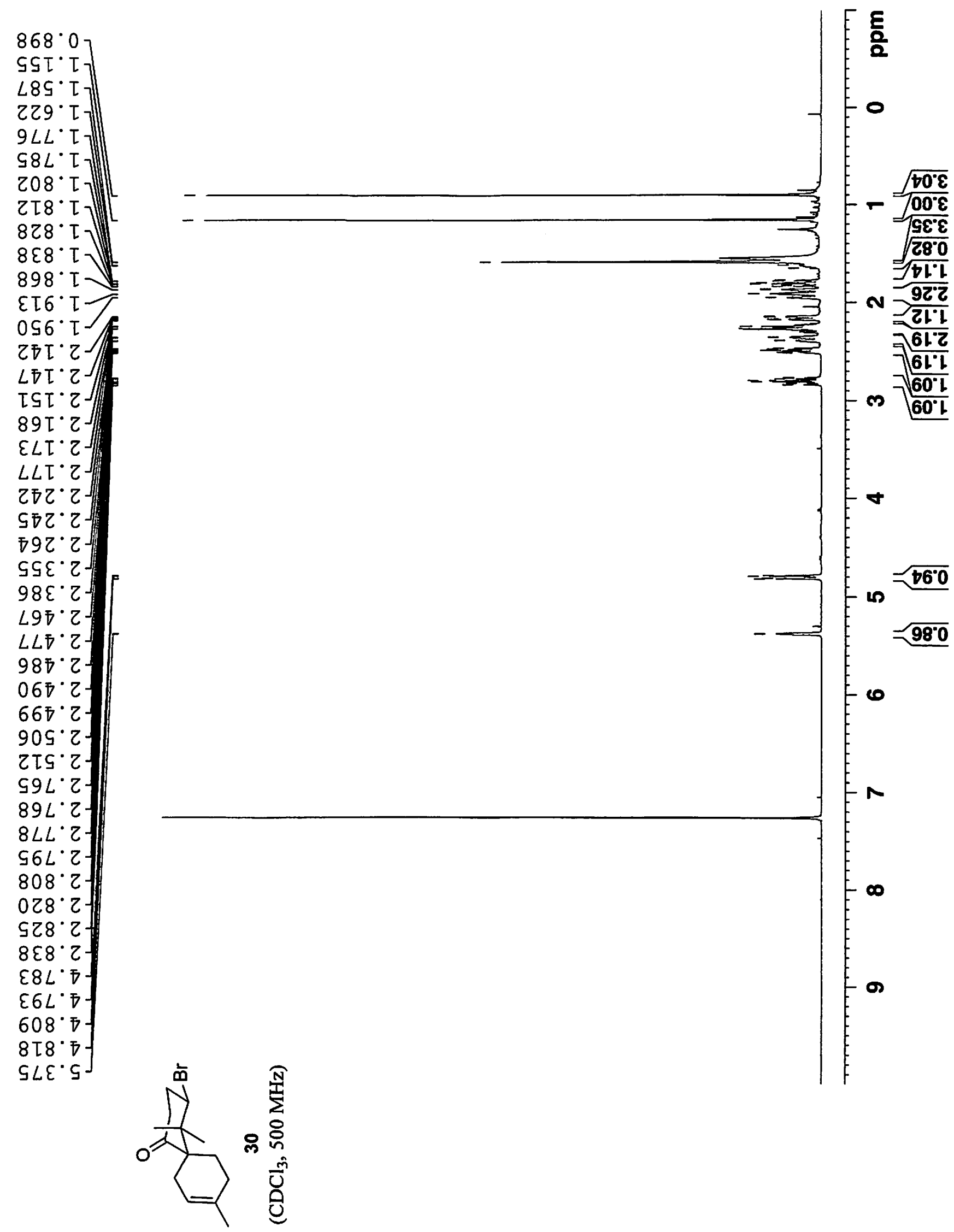




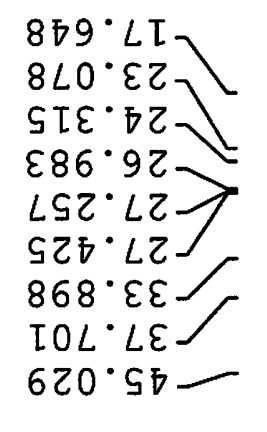

$670 \cdot 95$

$580^{\circ}$ โ9

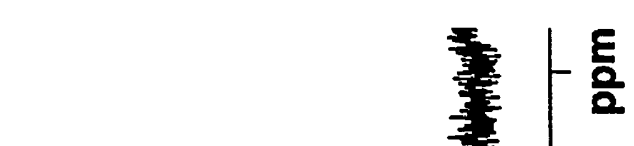

$00 S^{\circ} 02 \mathrm{~L}$

$99 \tau^{\circ} \tau \varepsilon \tau-$

$=2$

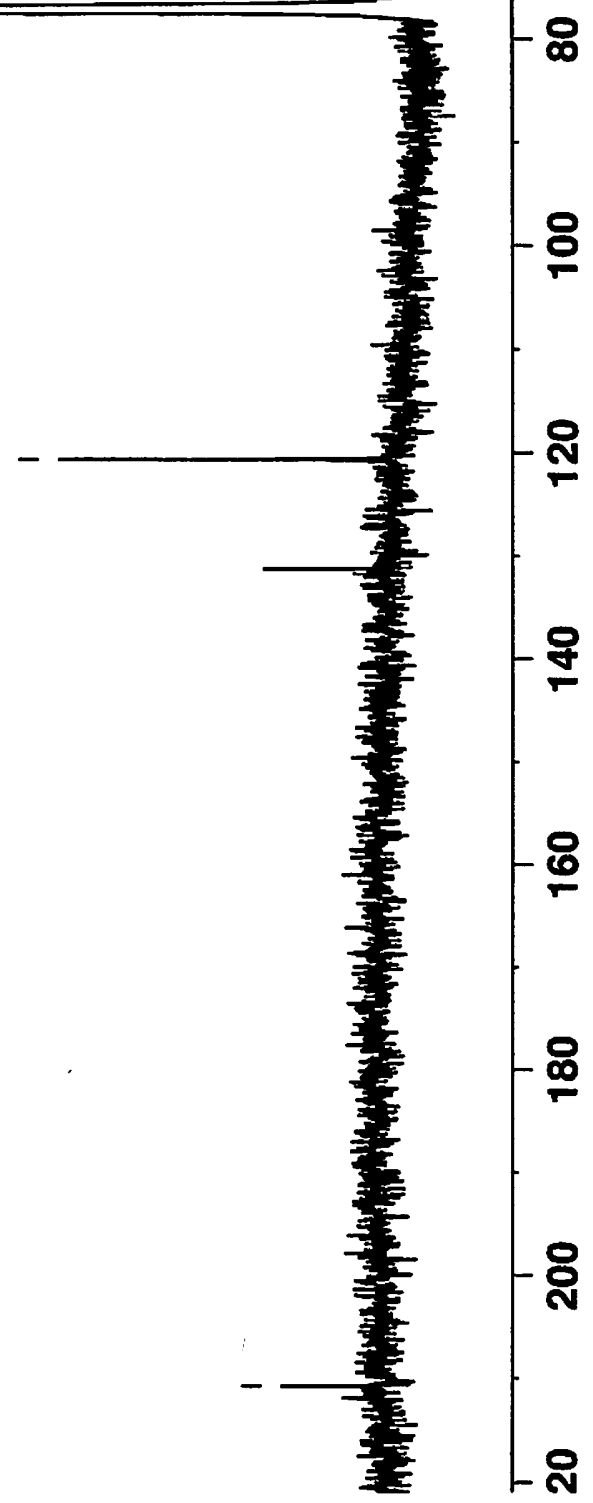

DOL OIZ 


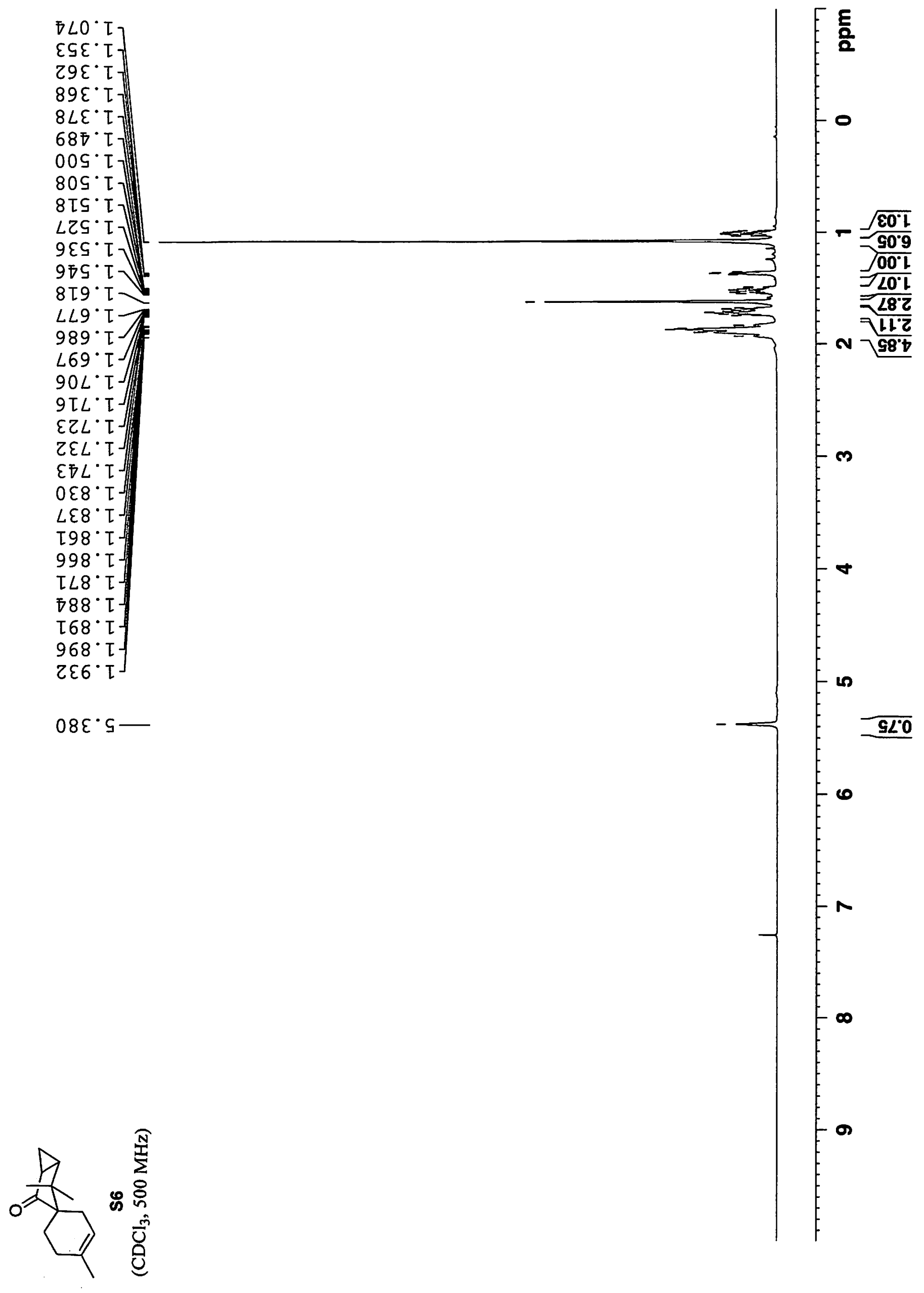




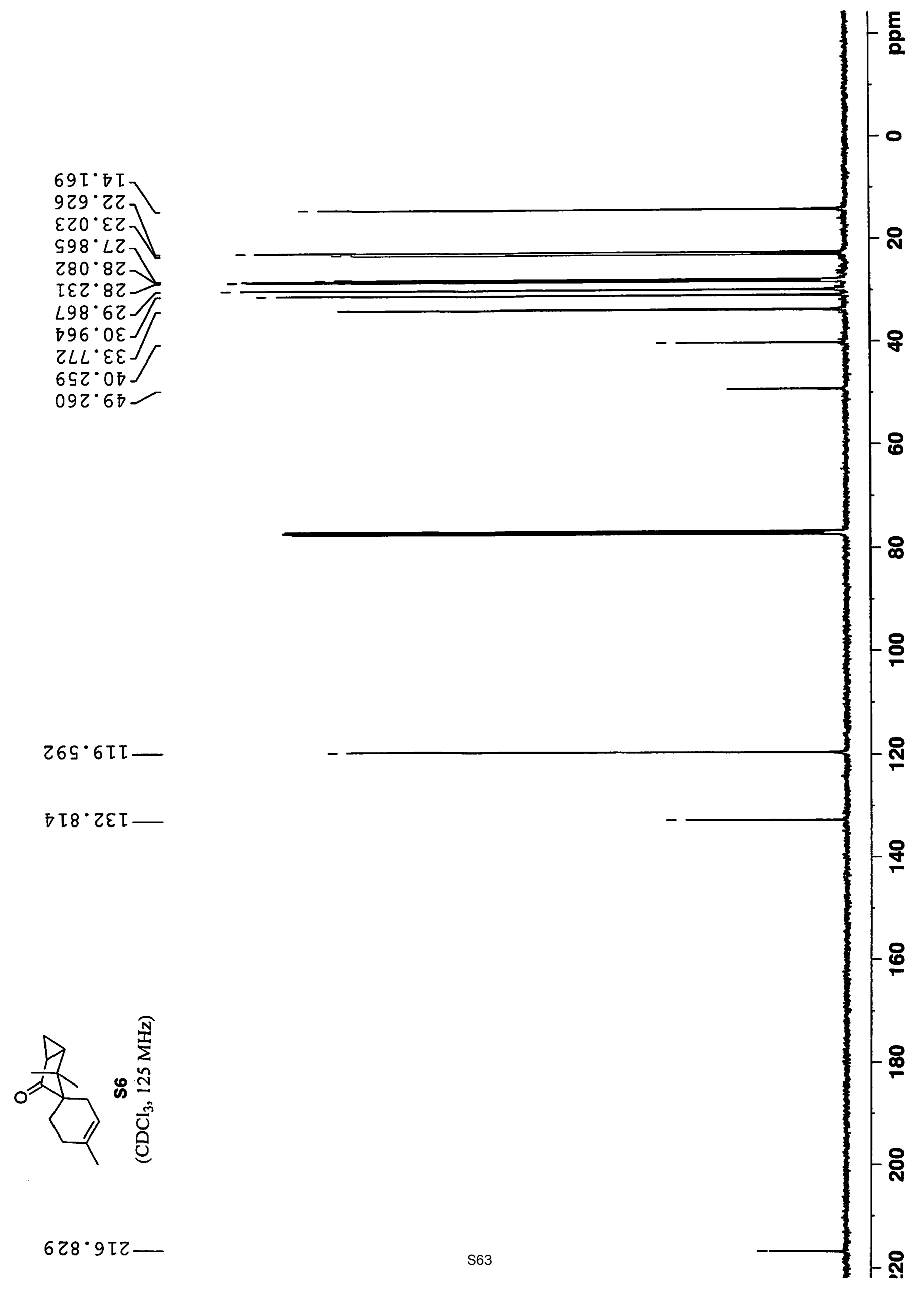



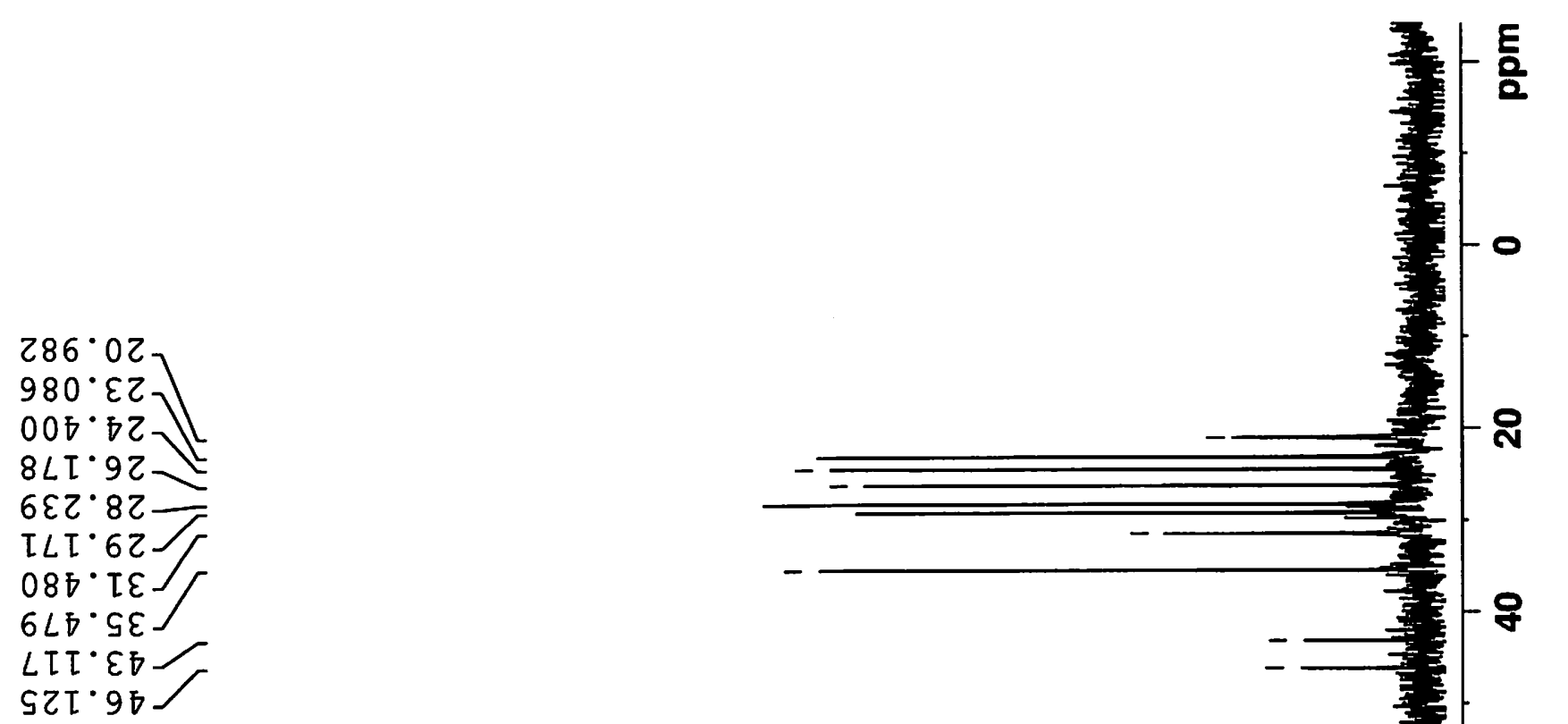

$S \varepsilon I \cdot 99$

DII・III

$9 Z L \cdot 8 I T$

$9 乙 乙 \cdot \varepsilon \varepsilon \tau$

$899^{\circ} \angle D I-$

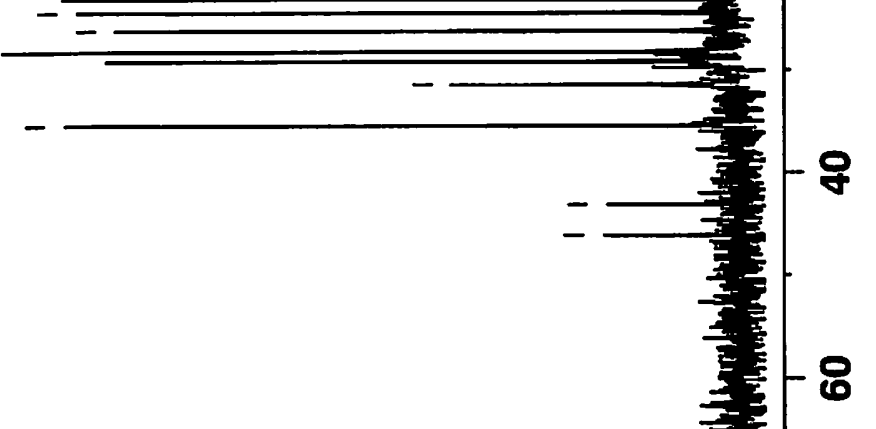




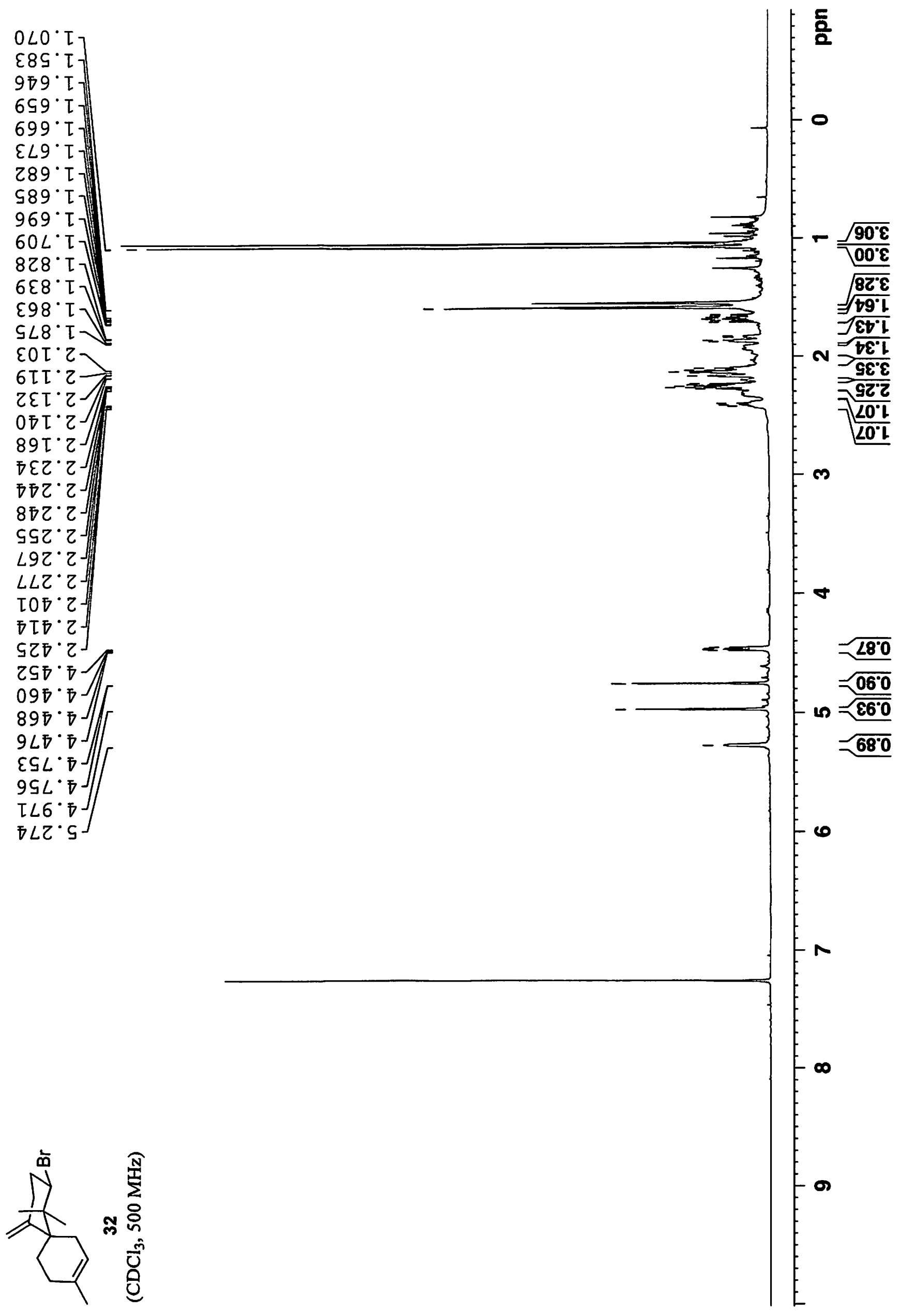




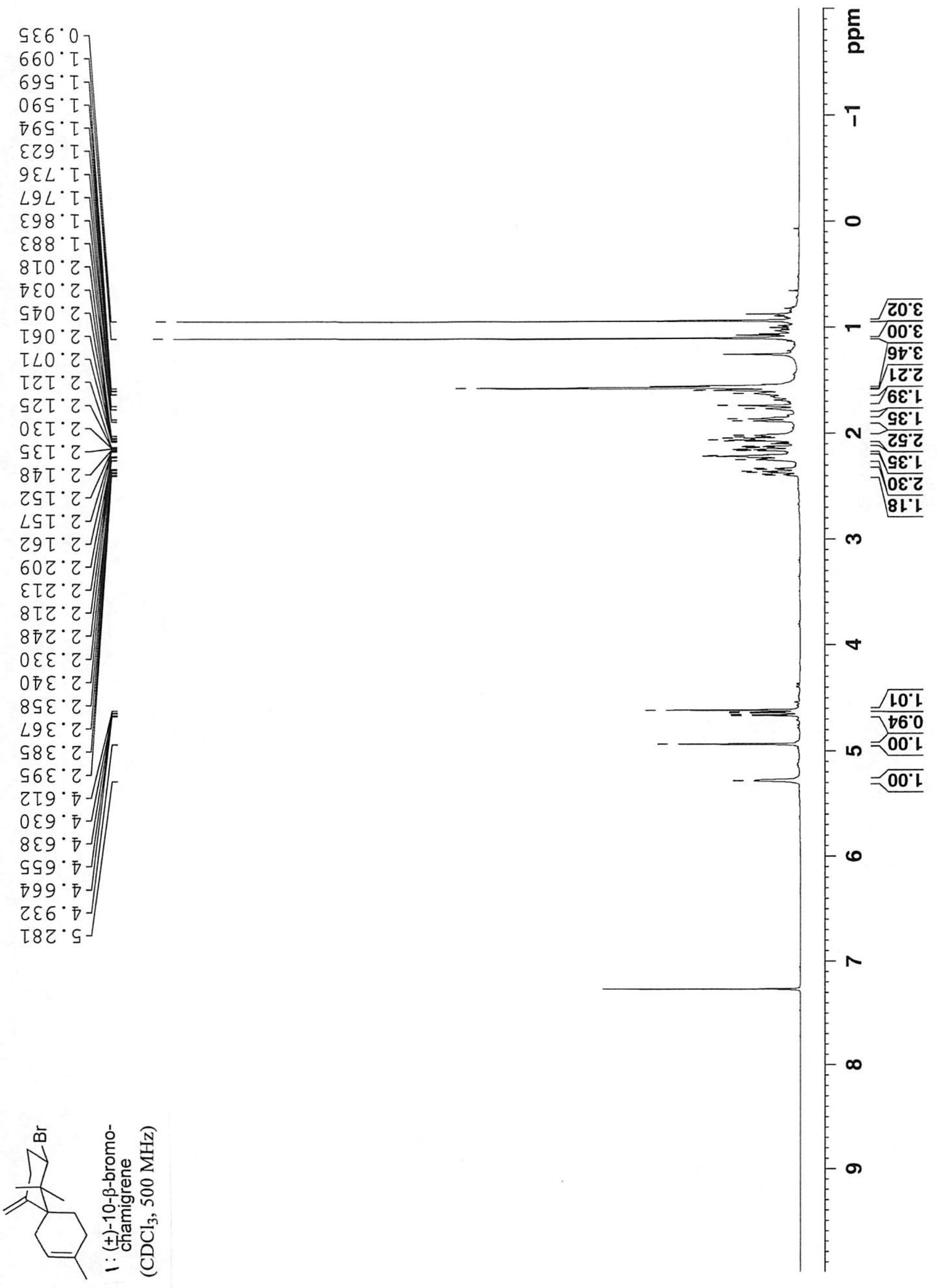



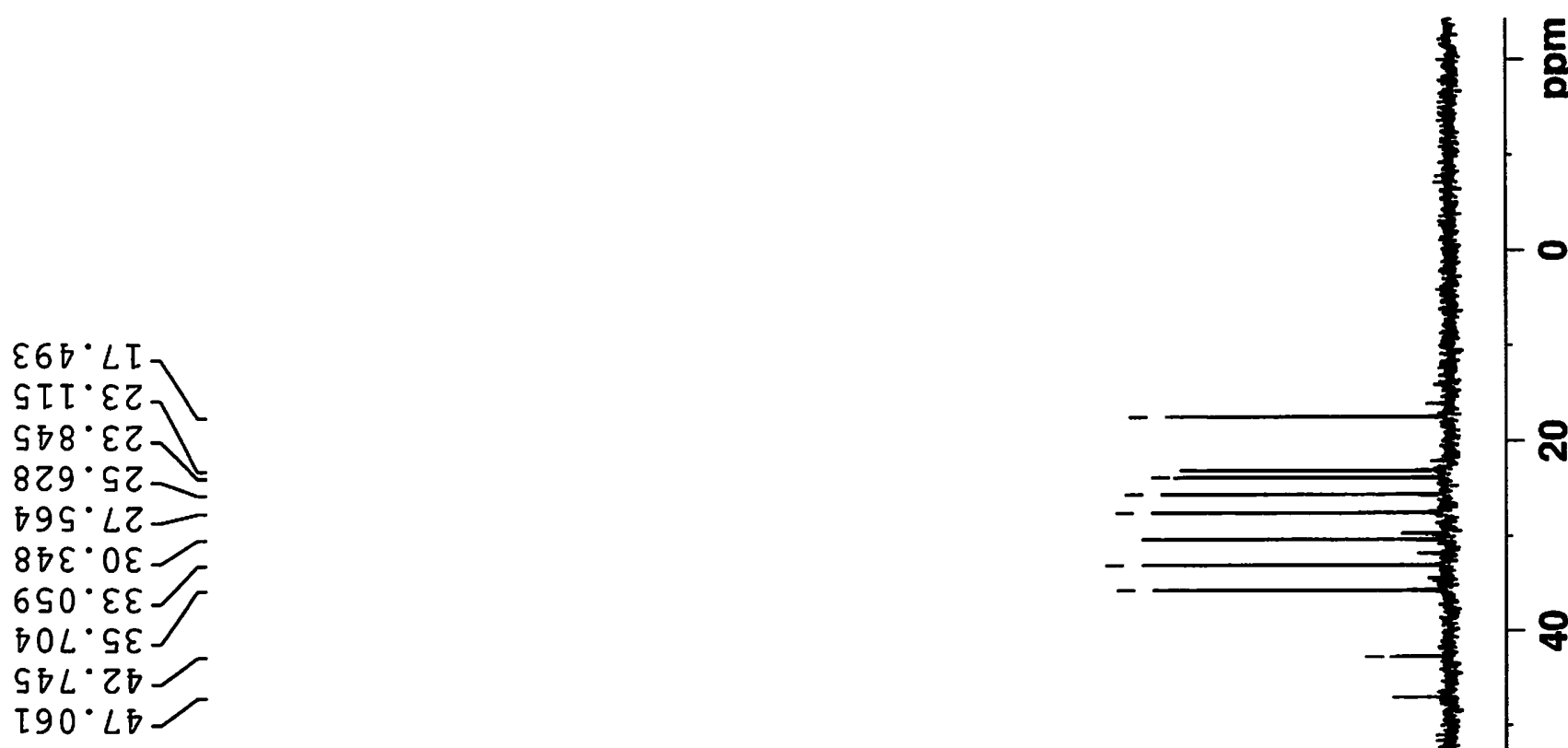

60I.99-

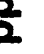

\&Z9 ZIL

SOL $6 \mathrm{II}$

ILL・ZEI-

Sถ $9^{\circ}$ SDL

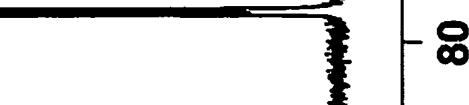

这

우

8

ำ

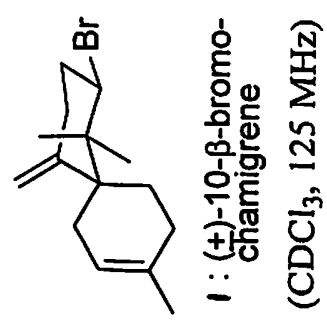




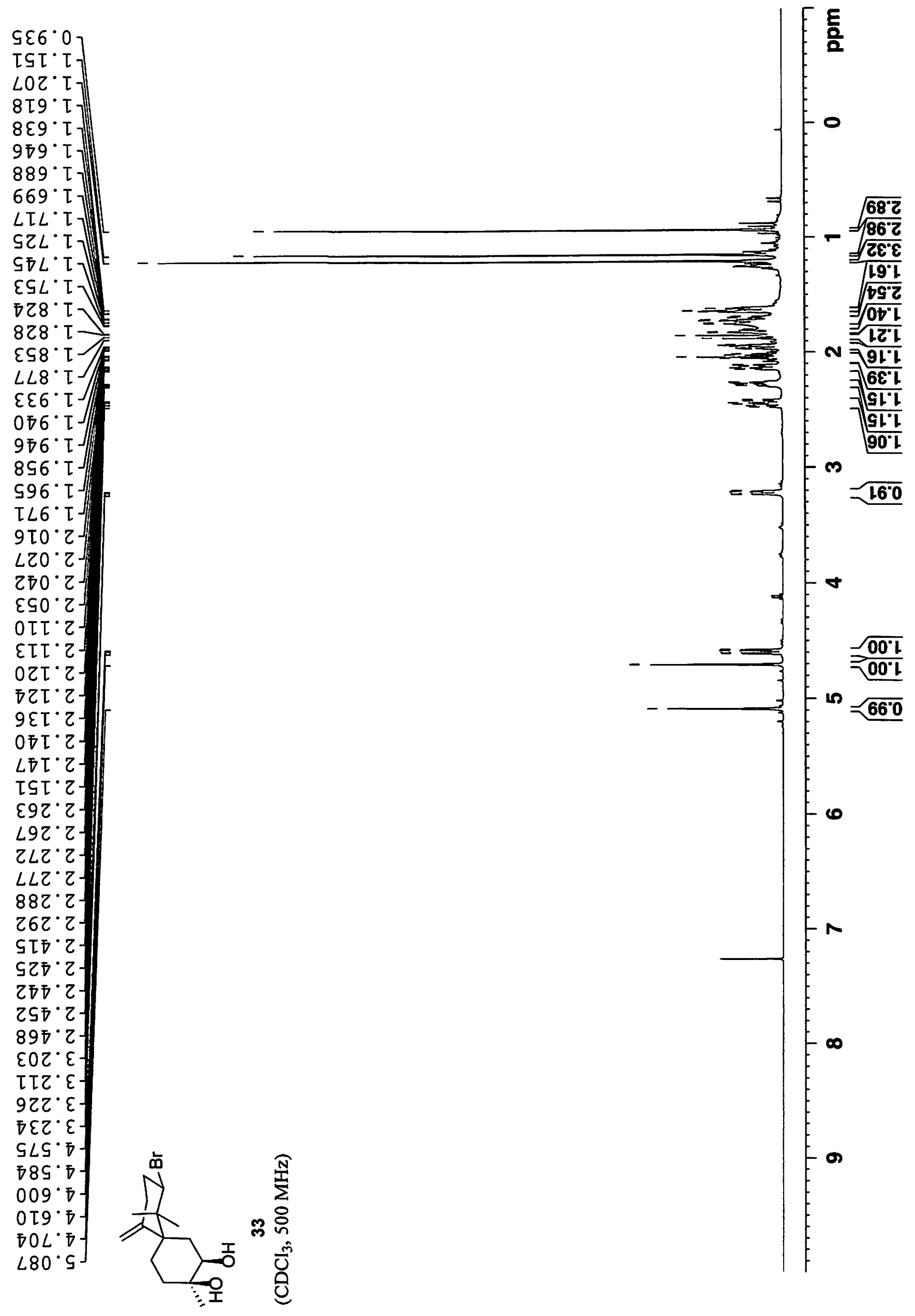



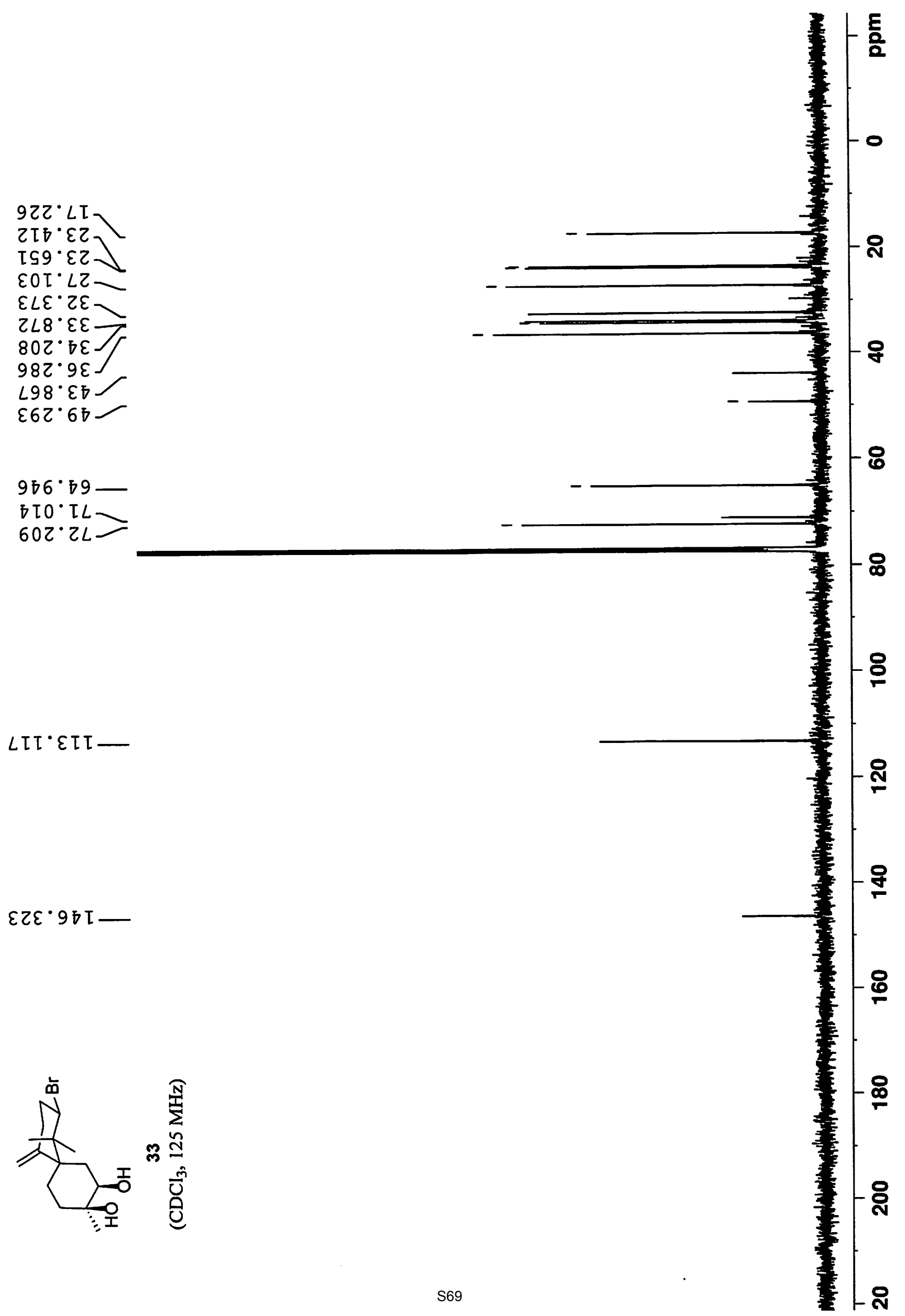


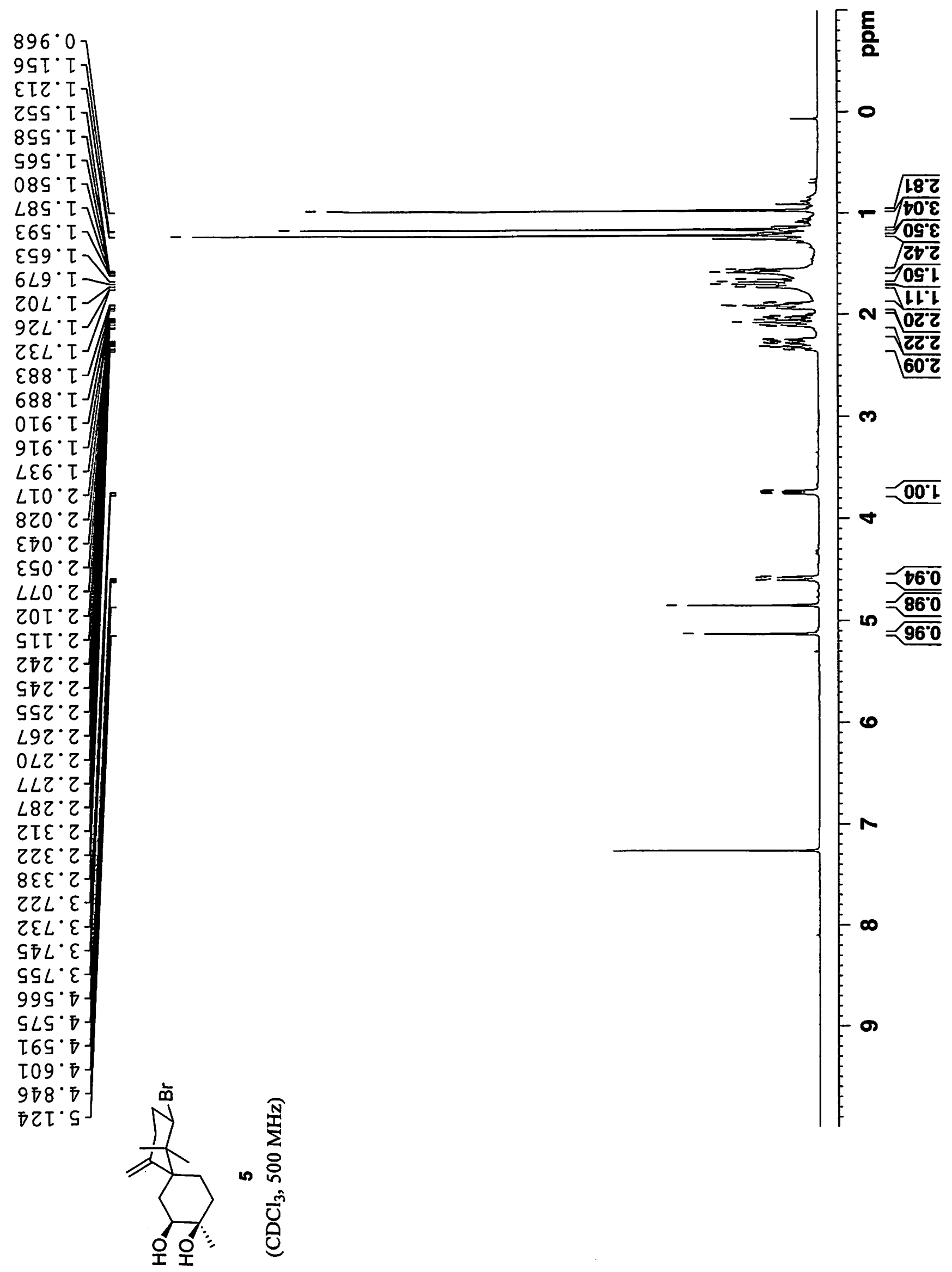




$$
11
$$




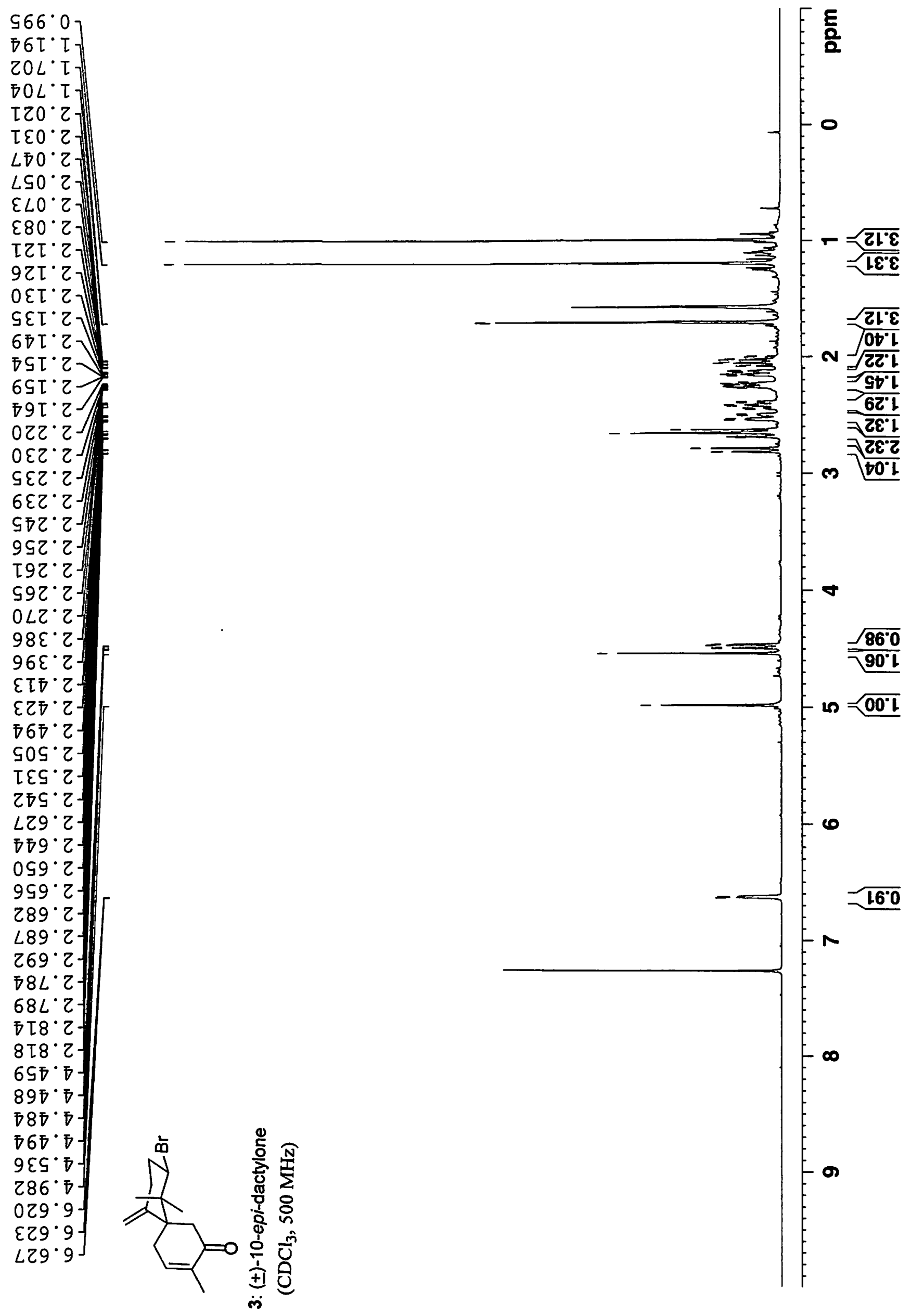




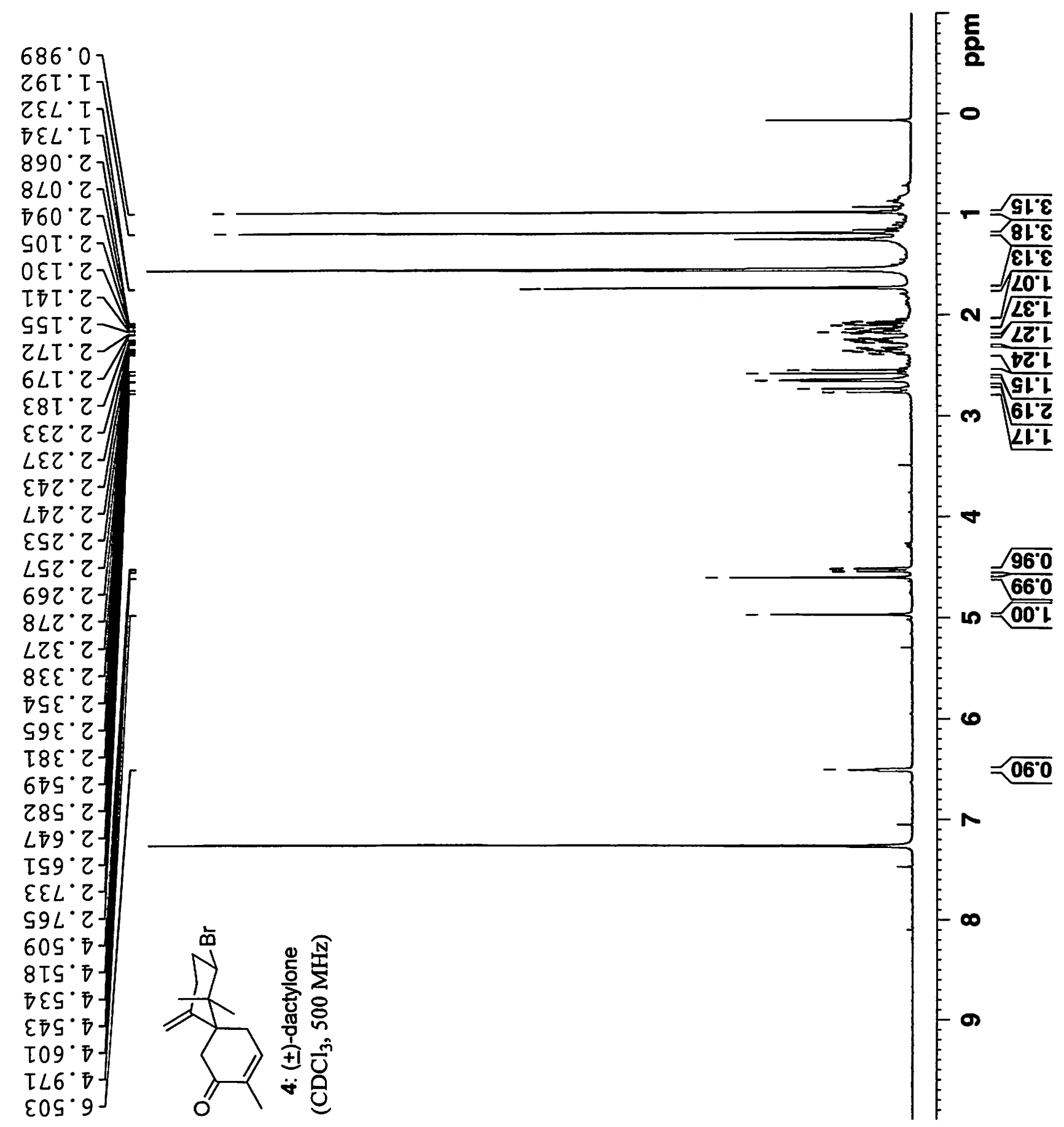


bै ' $\mathrm{GI}$

$86 \cdot \mathrm{LI}-$

$86.62-$

$2262-$

99. $\varepsilon \mathcal{~}$

枚

DO ${ }^{\circ} \mathrm{B}-$

61 'IS-

กI $89-$
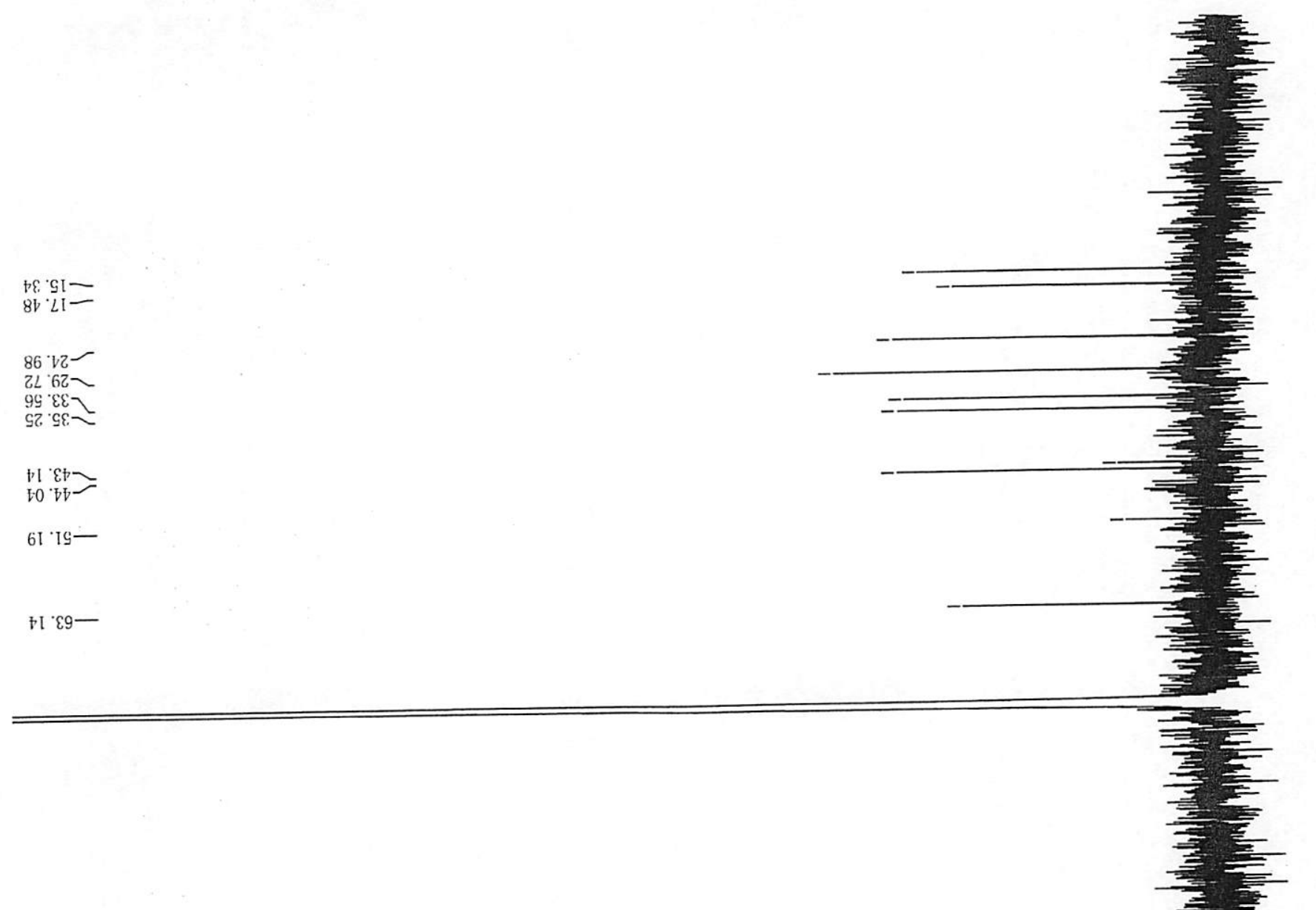

G6 㼛一

$\varepsilon \mathcal{E}{ }^{\circ} \mathrm{EI}-$

LE. IbI-

86 ' $\mathrm{VI}-$

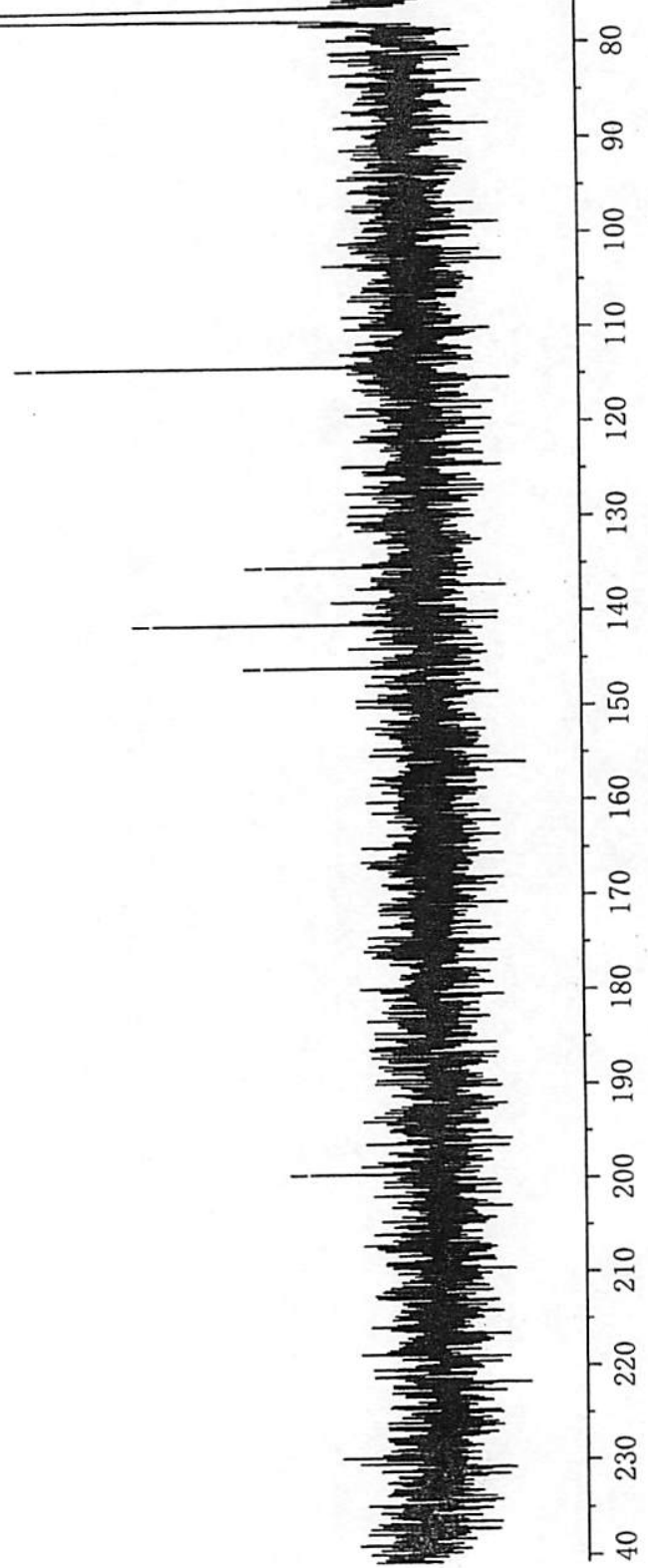

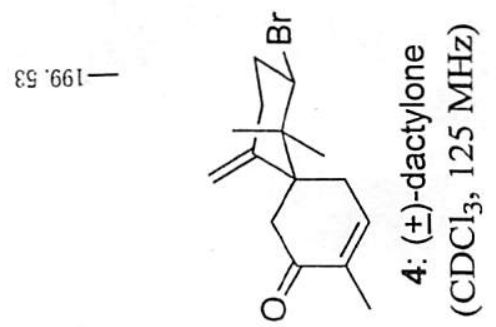

